\title{
National Assessment of Oil and Gas Project: Geologic Assessment of Undiscovered Gas Hydrate Resources on the North Slope, Alaska
}

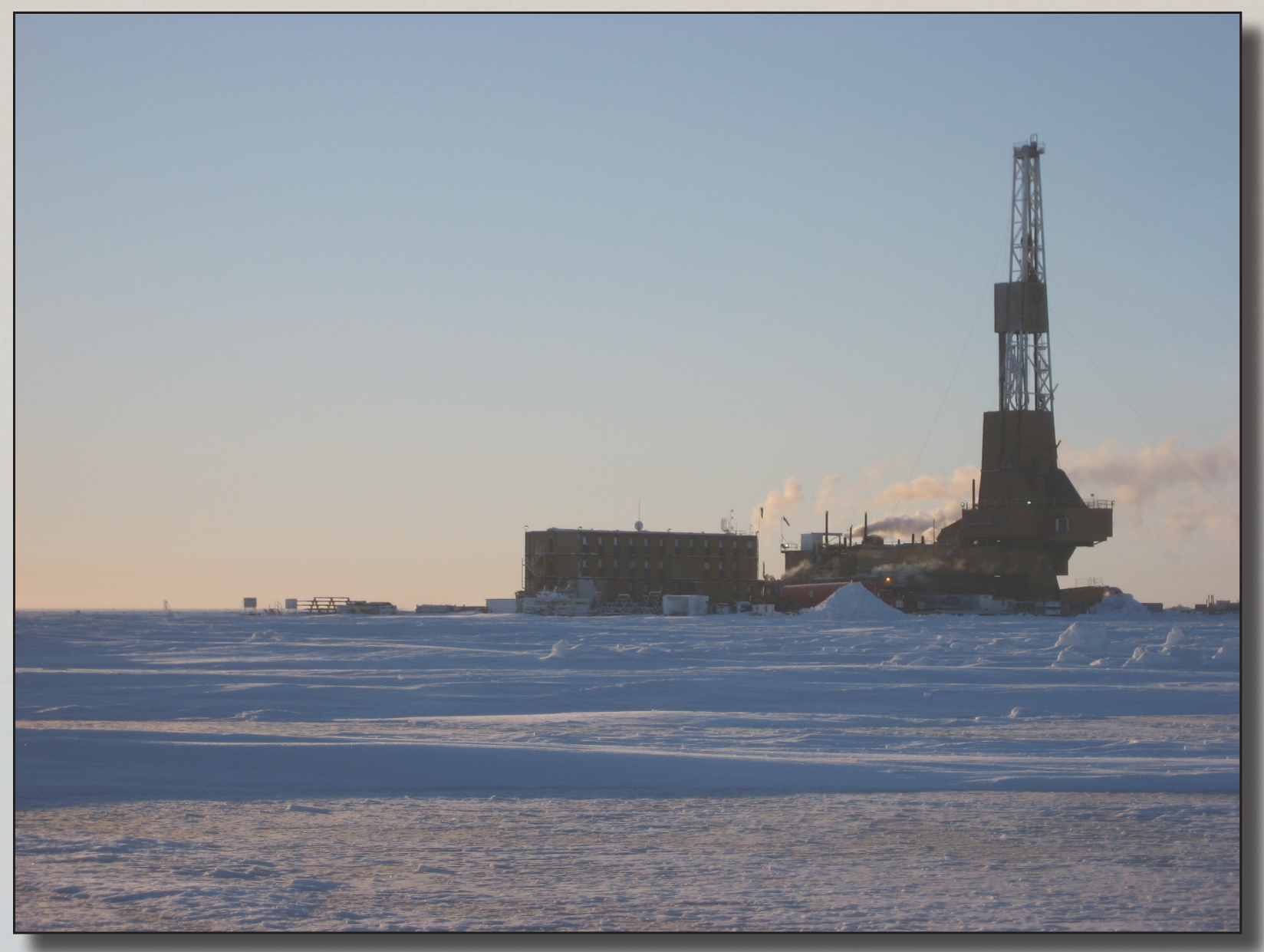

Click here to return to

Main Contents

Digital Data Series DDS-69-CC 


\section{National Assessment of Oil and Gas \\ Project: Geologic Assessment of \\ Undiscovered Gas Hydrate Resources \\ on the North Slope, Alaska}

By U.S. Geological Survey Alaska Gas Hydrate Assessment Team

Digital Data Series DDS-69-CC 


\title{
U.S. Department of the Interior SALLY JEWELL, Secretary
}

\section{U.S. Geological Survey Suzette M. Kimball, Acting Director}

\author{
U.S. Geological Survey, Reston, Virginia: 2013
}

For more information on the USGS - the Federal source for science about the Earth, its natural and living resources, natural hazards, and the environment, visit http://www.usgs.gov or call 1-888-ASK-USGS.

For an overview of USGS information products, including maps, imagery, and publications, visit http://www.usgs.gov/pubprod

To order this and other USGS information products, visit http://store.usgs.gov

Any use of trade, firm, or product names is for descriptive purposes only and does not imply endorsement by the U.S. Government.

Although this information product, for the most part, is in the public domain, it also may contain copyrighted materials as noted in the text. Permission to reproduce copyrighted items must be secured from the copyright owner.

Suggested citation:

U.S. Geological Survey Alaska Gas Hydrate Assessment Team, 2013, National Assessment of Oil and Gas ProjectGeologic assessment of undiscovered gas hydrate resources on the North Slope, Alaska: U.S. Geological Survey Digital Data Series 69-CC, 100 p., http://dx.doi.org/10.3133/ds69cc.

ISSN 2327-0271 (print) ISSN 2327-132x (online) 


\section{Contents}

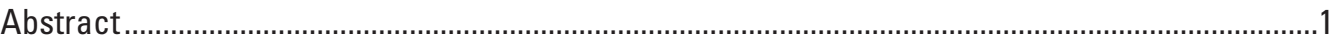

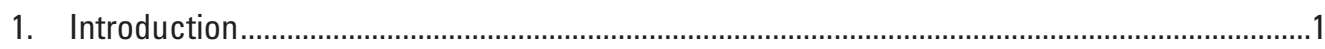

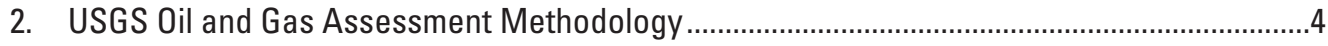

3. Gas Hydrate Technical Review...............................................................................

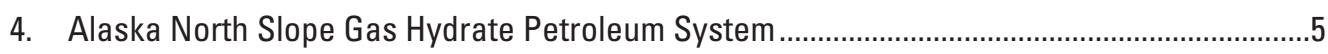

4.a. Gas Hydrate Stability Conditions ..........................................................................

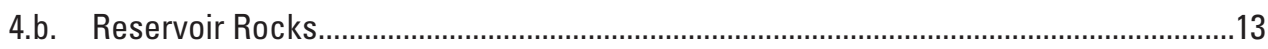

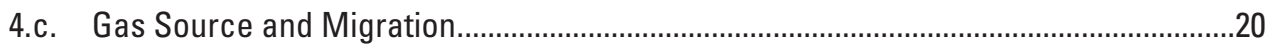

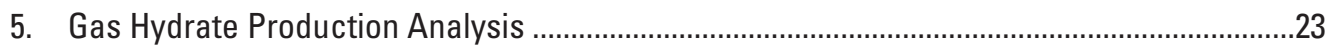

5.a. Gas Hydrate Production Testing Results.................................................................23

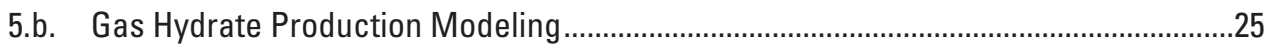

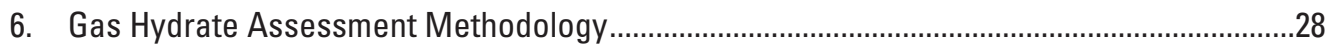

6.a. Northern Alaska Gas Hydrate Total Petroleum System and Assessment Units...........28

6.a.1. Nanushuk Formation Gas Hydrate Assessment Unit ......................................39

6.a.2. Tuluvak-Schrader Bluff-Prince Creek Formations Gas Hydrate Assessment Unit.................................................................................................. 40

6.a.3. Sagavanirktok Formation Gas Hydrate Assessment Unit................................41

6.b. Assessment Unit Probabilities ................................................................................ 41

6.c. Undiscovered Gas Hydrate Accumulations_-Sizes of Accumulations .........................42

6.d. Undiscovered Gas Hydrate Accumulations_-Number of Accumulations .....................45

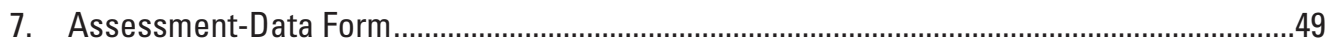

7.a. Identification Information ......................................................................................

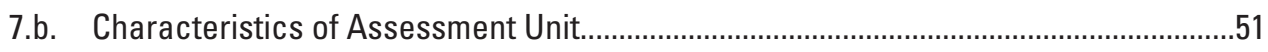

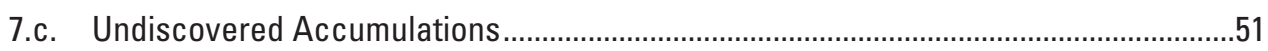

7.d. Assessment of Coproducts...........................................................................................

7.e. Selected Ancillary Data for Undiscovered Accumulations .............................................58

7.f. Allocations of Assessed Undiscovered Resources .....................................................58

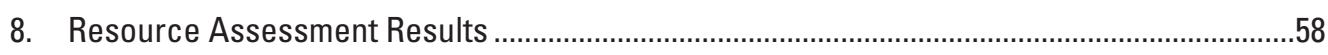

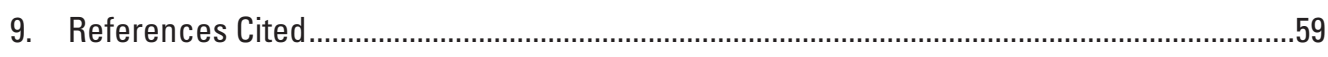

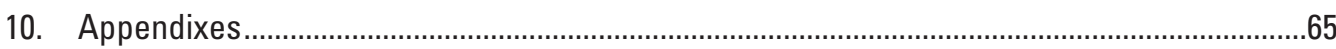

1. Basic input data (Seventh data form) used in estimates of the numbers and sizes of undiscovered gas hydrate accumulations in the Sagavanirktok Formation Gas Hydrate Assessment Unit (50010201) in the Northern Alaska Gas Hydrate Total Petroleum System.

2. Basic input data (Seventh data form) used in estimates of the numbers and sizes of undiscovered gas hydrate accumulations in the Tuluvak-Schrader Bluff-Prince Creek Formations Gas Hydrate Assessment Unit (50010202) in the Northern Alaska Gas Hydrate Total Petroleum System.

3. Basic input data (Seventh data form) used in estimates of the numbers and sizes of undiscovered gas hydrate accumulations in the Nanushuk Formation Gas Hydrate Assessment Unit (50010203) in the Northern Alaska Gas Hydrate Total Petroleum System. 


\section{Figures}

1. A, generalized geographic map of the Alaska North Slope showing the location of coastline, rivers, lakes, major political boundaries, villages, pipelines, and other features. $B$, map of the physiographic provinces and major tectonic features of the Alaska North Slope.

2. Flow diagram showing key steps in the USGS assessment model for undiscovered conventional oil and gas accumulations. .4

3. Gas hydrate phase diagram showing the depth and temperature conditions suitable for the formation of gas hydrate under various conditions of permafrost depth, geothermal gradient, gas chemistry, and a pore-pressure gradient of $0.433 \mathrm{psi} / \mathrm{ft}(9.795 \mathrm{kPa} / \mathrm{m})$..... . .6

4. Map showing the depth to base of permafrost on the Alaska North Slope as determined from equilibrated well-bore temperature surveys in 46 wells..

5. Maps of the Alaska North Slope gas hydrate stability zone: $A$, depth to the top of the hydrate stability zone; $B$, depth to base of the hydrate stability zone; $C$, thickness of the hydrate stability zone .9

6. Lithostratigraphic chart illustrating the relations between former and revised nomenclature of Mull and others (2003) for the Alaska North Slope..

7. A, downhole logs from the Northwest Eileen State-2 well depicting the depth of units $B, C, D$, and E; data shown include the natural gamma ray log, bulk-density, neutron porosity, acoustic velocity, and electrical resistivity data. $B$, insert of well logs from the cored gas hydrate interval (unit C) in the Northwest Eileen State-2 well

8. Well log cross section showing the lateral and vertical extent of the Eileen and Tarn gas hydrate accumulations and the associated underlying freegas zones in the Prudhoe Bay and Kuparuk River oil fields

9. Map of the Eileen and Tarn gas hydrate accumulations overlying portions of the Prudhoe Bay, Kuparuk River, and Milne Point oil fields.

10. Milne Point area gas hydrate prospects identified with 3-D seismic interpretation.

11. Milne Point Mount Elbert gas hydrate prospect

12. Open-hole well logs from the cored section of the Mount Elbert gas hydrate stratigraphic test well ..

13. Well-log-derived gas hydrate saturations, density porosities, and sediment permeabilities for the two gas-hydrate-bearing intervals (units $\mathrm{C}$ and $\mathrm{D}$ ) cored in the Mount Elbert gas hydrate stratigraphic test well.

14. Schematic west to east cross section through the Prudhoe Bay and Kuparuk River fields illustrating possible gas-migration paths and spatial relations between the Eileen and Tarn gas hydrate accumulations, free-gas and oil accumulations, Eileen and other fault zones, and base of gas hydrate stability.....

15. Montage of log data from wells drilled in Prudhoe Bay Unit (PBU),

Kuparuk River Unit (KRU), and Milne Point Unit (MPU) areas

16. Comparison of typical production simulation results for Alaska North Slope gas hydrate reservoirs. 
17. Hydrate saturation in the Prudhoe Bay Unit (PBU) L-106 well as calculated by the Archie (1942) relation for $n=1.5,2.0$ (model $S_{H}$ ), and 2.5

18. Predicted gas and water production from the Prudhoe Bay Unit (PBU)

L-106 C-unit methane hydrate deposit for a constant bottom-hole pressure of 2.7 megapascals

19. A, map of the Northern Alaska Gas Hydrate Total Petroleum System (TPS) (500102), B, map of the Northern Alaska Gas Hydrate TPS and the gas hydrate stability zone thickness contours from figure $5 C$...

20. Map of the Nanushuk Formation Gas Hydrate Assessment Unit (AU)

21. Map of the Tuluvak-Schrader Bluff-Prince Creek Formations Gas Hydrate Assessment Unit (AU) .

22. Map of the Sagavanirktok Formation Gas Hydrate Assessment Unit (AU).

23. Map showing locations of well-log correlation sections within the greater Prudhoe Bay area as compiled by Lewis and others (2013).

24. Map of 2D and 3D seismic profiles, the interpretation of which were used as the base data for this assessment of undiscovered gas hydrate resources on the Alaska North Slope

25. Maps showing pre-drill estimates of $A$, gas hydrate saturation, and $B$, reservoir thickness for hydrate unit $\mathrm{C}$ in the Mount Elbert prospect

26. Gas hydrate recovery ratio (percent of in-place gas within gas hydrates that would be recovered) as a product of the producing well abandonment pressure (pressure is shown as a percent of hydrostatic pore pressure) ..

27. Bar-graph showing sizes of 3D-imaged gas hydrate accumulations in $A$, the Milne Point Unit (MPU) and $B$, the National Petroleum Reserve in Alaska (NPRA)

28. Bar-graph showing sizes of the $3 \mathrm{D}$-imaged gas hydrate accumulations in $A$, the Milne Point Unit (MPU), and $B$, the National Petroleum Reserve in Alaska (NPRA), that have been modified to account for larger and smaller inferred gas hydrate accumulations in the MPU and NPRA, respectively.

29. Map showing locations of the wells of opportunity (table 5) from which the analysis of gas samples were used to ascertain the composition and source of the gas within each of the gas hydrate assessment units in northern Alaska

30. A, map of the Nanushuk Formation Gas Hydrate Assessment Unit showing areas outlined with high, middle or low "gas hydrate discovery ratiodistributions" $B$, same as $A$, but also includes locations of wells of opportunity and discovered oil and gas fields from figure 29.

31. A, map of the Tuluvak-Schrader Bluff-Prince Creek Formations Gas Hydrate Assessment Unit showing areas outlined with high, middle or low "gas hydrate discovery ratio-distributions". $B$, same as $A$, but also includes locations of wells of opportunity and discovered oil and gas fields from figure 29 .

32. A, Map of the Sagavanirktok Formation Gas Hydrate Assessment Unit with the areas outlined with high, middle or low "gas hydrate discovery ratiodistributions"; $B$, with location of wells of opportunity and discovered oil and gas fields. 


\section{Tables}

1. List of Alaska North Slope wells with equilibrated borehole temperature surveys along with the estimated depth of the base of permafrost $\left(0^{\circ} \mathrm{C}\right)$ and the depth to the top (THSZ) and base (BHSZ) of the gas hydrate stability zone.

2. Cross-reference of the gas hydrate assessment units with USGS conventional assessment units in northern Alaska

3. List of 3D seismic imaged gas hydrate accumulations in the Milne Point Unit and the National Petroleum Reserve in Alaska, listed by the name of the accumulation and associated gas hydrate assessment unit.

4. Determinations of "gas hydrate discovery ratio—distributions" resulting from the Milne Point Unit and the National Petroleum Reserve in Alaska 3D seismic gas hydrate prospecting effort.

5. List of wells of opportunity in which analyses of gas samples have been used to ascertain the composition and source of the gas within each of the gas hydrate assessment units in northern Alaska.

6. List of conventional oil and gas fields used in part to assign "gas hydrate discovery ratio-distributions" to various portions of the gas hydrate assessment units

7. Estimates of the number of undiscovered gas hydrate accumulations in the Nanushuk Formation Gas Hydrate Assessment Unit.

8. Estimates of the number of undiscovered gas hydrate accumulations in the Tuluvak-Schrader Bluff-Prince Creek Formations Gas Hydrate Assessment Unit.

9. Estimates of the number of undiscovered gas hydrate accumulations in the Sagavanirktok Formation Gas Hydrate Assessment Unit. .58

10. Alaska North Slope-Gas hydrate assessment results.

\section{Conversion Factors}

Inch/Pound to SI

\begin{tabular}{lcl}
\hline Multiply & By & To obtain \\
\hline inch (in.) & Length & \\
inch (in.) & 2.54 & centimeter $(\mathrm{cm})$ \\
foot $(\mathrm{ft})$ & 25.4 & millimeter $(\mathrm{mm})$ \\
mile (mi) & 0.3048 & meter $(\mathrm{m})$ \\
\hline & 1.609 & kilometer $(\mathrm{km})$ \\
\hline square inch $\left(\mathrm{in}^{2}\right)$ & Area & \\
square mile $\left(\mathrm{mi}^{2}\right)$ & 6.452 & square centimeter $\left(\mathrm{cm}^{2}\right)$ \\
square mile $\left(\mathrm{mi}^{2}\right)$ & 259.0 & hectare $($ ha) \\
& 2.590 & square kilometer $\left(\mathrm{km}^{2}\right)$ \\
\hline cubic foot $\left(\mathrm{ft}^{3}\right)$ & Volume & \\
cubic foot $\left(\mathrm{ft}^{3}\right)$ & 28.32 & cubic decimeter $\left(\mathrm{dm}^{3}\right)$ \\
\hline & 0.02832 & cubic meter $\left(\mathrm{m}^{3}\right)$ \\
\hline pound per square foot $\left(\mathrm{lb} / \mathrm{ft}^{2}\right)$ & Pressure & \\
pound per square inch $\left(\mathrm{lb} / \mathrm{in}^{2}\right)$ & 0.04788 & kilopascal $(\mathrm{kPa})$ \\
& 6.895 & kilopascal $(\mathrm{kPa})$ \\
\hline pound per cubic foot $\left(\mathrm{lb} / \mathrm{ft}^{3}\right)$ & Density & \\
pound per cubic foot $\left(\mathrm{lb} / \mathrm{ft}^{3}\right)$ & 16.02 & kilogram per cubic meter $\left(\mathrm{kg} / \mathrm{m}^{3}\right)$ \\
\hline
\end{tabular}

Temperature in degrees Fahrenheit $\left({ }^{\circ} \mathrm{F}\right)$ may be converted to degrees Celsius $\left({ }^{\circ} \mathrm{C}\right)$ as follows: 


\section{Acronyms Used in Report}

$\begin{array}{ll}\text { USGS } & \text { U.S. Geological Survey } \\ \text { TCF } & \text { trillion cubic feet } \\ \text { BLM } & \text { U.S. Bureau of Land Management } \\ \text { NPRA } & \text { National Petroleum Reserve in Alaska } \\ \text { ANWR } & \text { Arctic National Wildlife Reserve } \\ \text { TPS } & \text { Total Petroleum System } \\ \text { AU } & \text { assessment unit } \\ \text { SI } & \text { Structure I Hydrate } \\ \text { SII } & \text { Structure II Hydrate } \\ \text { SH } & \text { Structure H Hydrate } \\ \text { MDT } & \text { Schlumberger Modular Dynamic Testing } \\ \text { DOE } & \text { U.S. Department of Energy } \\ \text { JOGMEC } & \text { Japan Oil, Gas and Metals National Corporation } \\ \text { MPU } & \text { Milne Point Unit, } \\ \text { NRCan } & \text { Natural Resources Canada } \\ \text { KRU } & \text { Kuparak River Unit } \\ \text { PBU } & \text { Prudhoe Bay Unit }\end{array}$





\title{
National Assessment of Oil and Gas Project: Geologic Assessment of Undiscovered Gas Hydrate Resources on the North Slope, Alaska
}

\author{
By U.S. Geological Survey Alaska Gas Hydrate Assessment Team
}

\begin{abstract}
Scientists with the U.S. Geological Survey have completed the first assessment of the undiscovered, technically recoverable gas hydrate resources beneath the North Slope of Alaska. This assessment indicates the existence of technically recoverable gas hydrate resources- that is, resources that can be discovered, developed, and produced using current technology.

The approach used in this assessment followed standard geology-based USGS methodologies developed to assess conventional oil and gas resources. In order to use the USGS conventional assessment approach on gas hydrate resources, three-dimensional industry-acquired seismic data were analyzed. The analyses indicated that the gas hydrates on the North Slope occupy limited, discrete volumes of rock bounded by faults and downdip water contacts. This assessment approach also assumes that the resource can be produced by existing conventional technology, on the basis of limited field testing and numerical production models of gas hydrate-bearing reservoirs.

The area assessed in northern Alaska extends from the National Petroleum Reserve in Alaska on the west through the Arctic National Wildlife Refuge on the east and from the Brooks Range northward to the State-Federal offshore boundary (located 3 miles north of the coastline). This area consists mostly of Federal, State, and Native lands covering 55,894 square miles. Using the standard geology-based assessment methodology, the USGS estimated that the total undiscovered technically recoverable natural-gas resources in gas hydrates in northern Alaska range between 25.2 and 157.8 trillion cubic feet, representing 95 percent and 5 percent probabilities of greater than these amounts, respectively, with a mean estimate of 85.4 trillion cubic feet.
\end{abstract}

\section{Introduction}

Approximately 35 years (yr) ago, Russian scientists made what was then a bold assertion that gas hydrates, long a curiosity of physical chemists, should occur in nature. Since then, the U.S. Geological Survey (USGS) and others have built a strong scientific foundation supporting the conclusion that gas hydrates are a global phenomenon containing potentially huge volumes of gas in terrestrial polar regions and the deep-water portions of most continental margins. Gas hydrates are naturally occurring, ice-like solids in which water molecules trap gas molecules in a cage-like structure known as a clathrate. Although many gases form hydrates in nature, methane hydrate is by far the most common. In 1995, the USGS conducted the first systematic assessment of the in-place natural gas hydrate resources of the United States (Collett, 1995). That study suggests that the amount of gas in the Nation's hydrate accumulations greatly exceeds the volume of known conventional domestic gas resources. The 1995 USGS assessment also estimated that the permafrostassociated gas hydrates on the Alaska North Slope may contain as much as 590 trillion cubic feet (TCF) of in-place gas. Two large gas hydrate accumulations have been identified in the Prudhoe Bay area. The in-place volume of gas estimated within the known gas hydrates in the greater Prudhoe Bay area infrastructure area alone may exceed 100 TCF (Collett, 2002). However, it is important to note that none of the previously published gas hydrate assessments have predicted how much gas could actually be produced from the gas hydrate accumulations in northern Alaska.

In recognition of the importance of gas hydrates as a potential energy resource, the USGS and the U.S. Bureau of Land Management (BLM) entered into an Assistance Agreement in 2002 to assess the volume of gas that could be produced from gas hydrates in northern Alaska. The primary objective of this assessment was to conduct a geology-based analysis of the occurrence of gas hydrates within northern Alaska to determine the role gas hydrate may play as a future domestic-energy resource. This project included three concurrent phases. Phase I focused on the Eileen gas hydrate occurrences in the greater Prudhoe Bay area (fig. 1A-B). Phase II dealt with identifying and characterizing potential gas hydrate accumulations on federally-managed lands in National Petroleum Reserve in Alaska (NPRA) and Arctic National Wildlife Refuge (ANWR), and on lands managed by the State of Alaska between the Colville and Canning Rivers (fig. $1 A-B$ ). Phase III entailed a systematic, geologybased appraisal of the volume of gas that can be technically produced from gas hydrates on the North Slope. 


\section{$\boldsymbol{A}$}

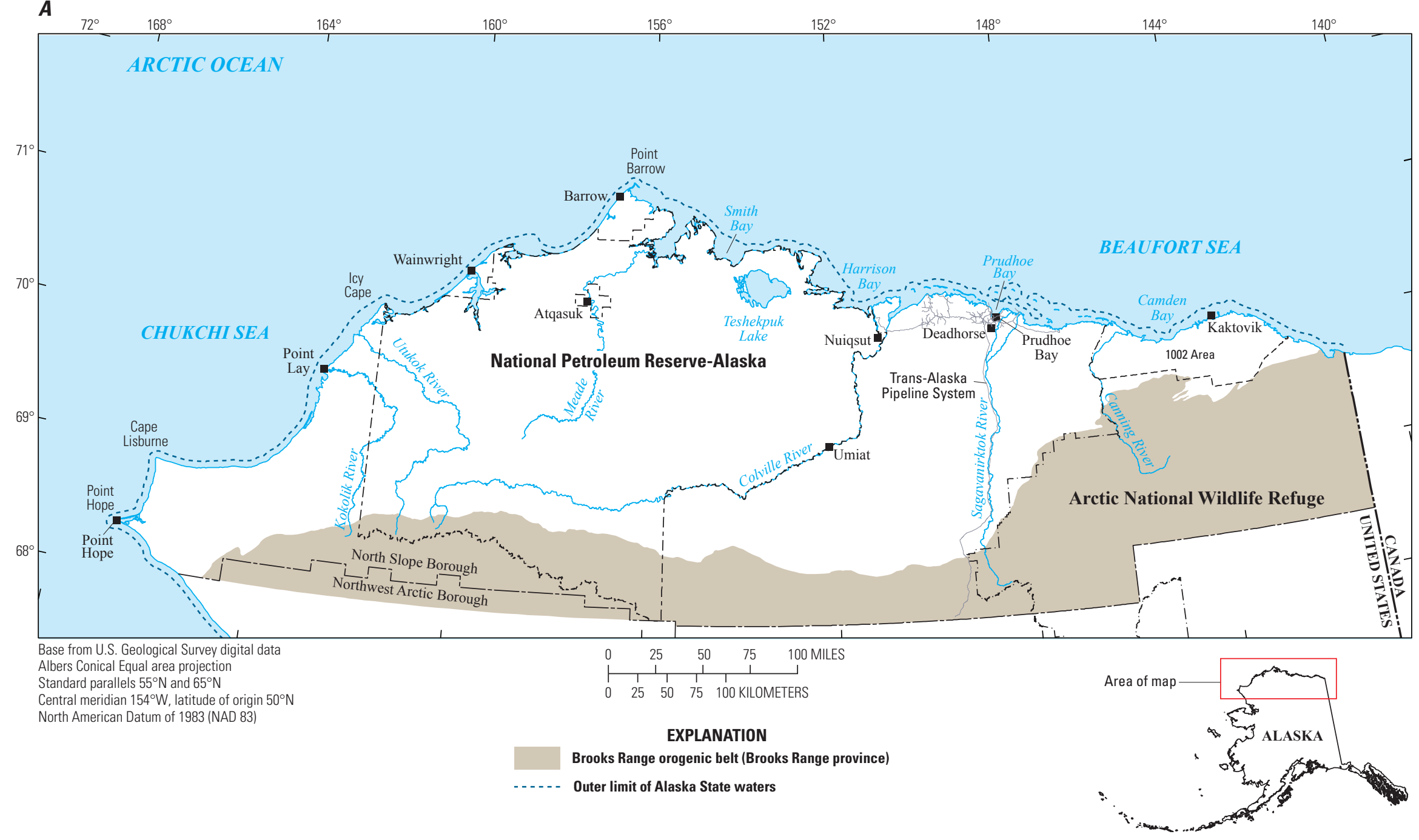

Figure 1. A, generalized geographic map of the Alaska North Slope showing the location of coastline, rivers, lakes, major political boundaries, villages, pipelines, and other features. $B$, map of the physiographic provinces and major tectonic features of the Alaska North Slope (modified from Collett, 1993, 2002). (NPRA, National Petroleum Reserve in Alaska; ANWR, Arctic National Wildlife refuge; TAPS, Trans Alaska Pipeline System) 


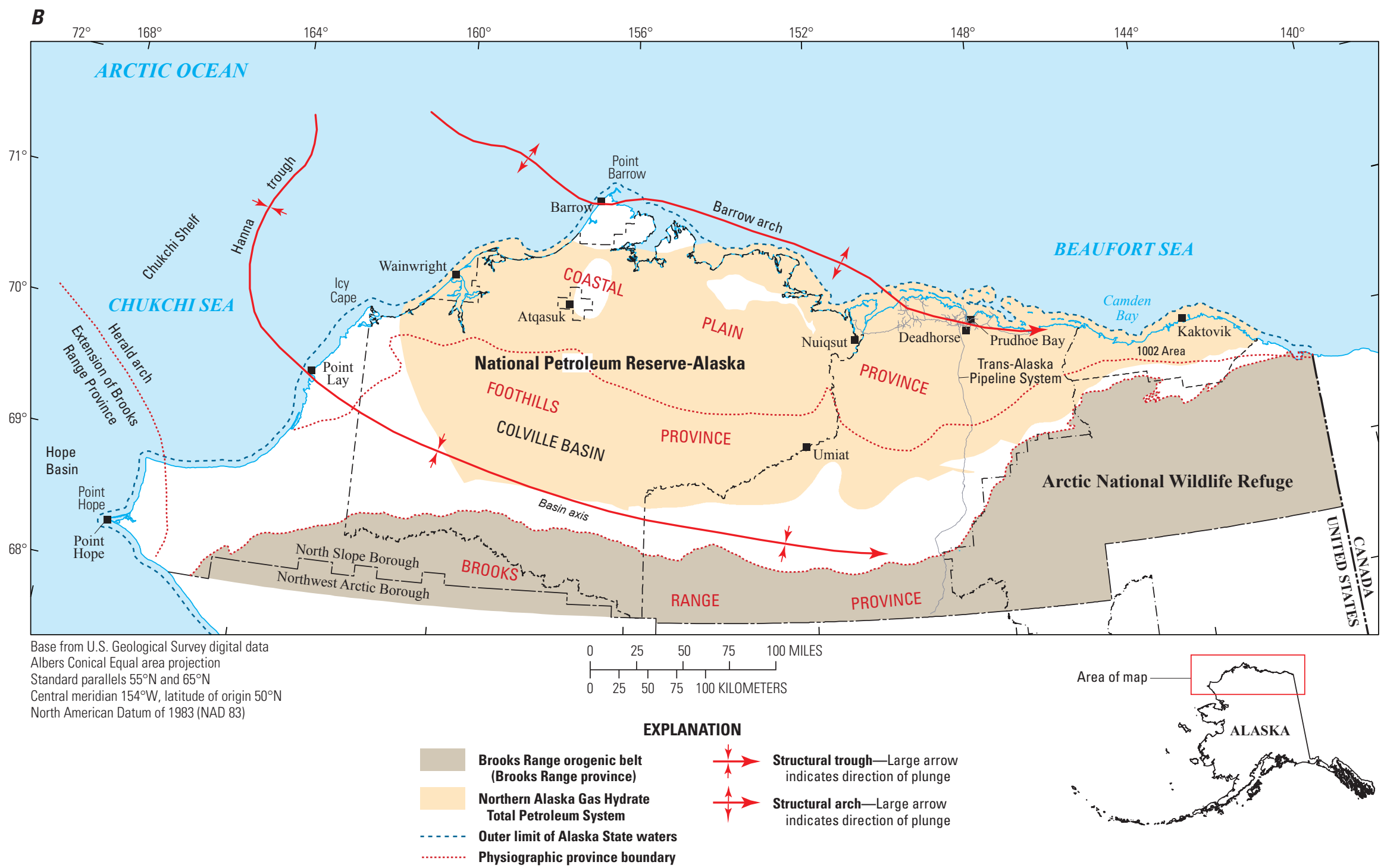

Figure 1. A, generalized geographic map of the Alaska North Slope showing the location of coastline, rivers, lakes, major political boundaries, villages, pipelines, and other features. $B$, map of the physiographic provinces and major tectonic features of the Alaska North Slope (modified from Collett, 1993, 2002). (NPRA, National Petroleum Reserve in Alaska; ANWR, Arctic National Wildlife refuge; TAPS, Trans Alaska Pipeline System)—Continued 
This report provides a comprehensive review of the USGS assessment of the undiscovered, technically recoverable gas hydrate resources on the Alaska North Slope. This report begins with a review of the USGS assessment methodology used in this study, which is followed by a discussion of what gas hydrates are and a description of some of their more important physical properties. The concept of the gas hydrate petroleum system is introduced, followed by a review of the geologic controls that affect the formation and presence of gas hydrates in northern Alaska. This report also includes a detailed review of the results of gas hydrate-production testing and modeling in Alaska and other comparable settings. The main body of this report deals with the actual Alaska North Slope assessment input requirements and results.

\section{USGS Oil and Gas Assessment Methodology}

For the first time, the USGS has assessed gas hydrates, a traditionally unconventional resource with no confirmed production history, as a producible resource occurring in discrete hydrocarbon traps and structures. The approach used in this assessment of gas hydrate resources in northern Alaska followed standard geology-based USGS methodologies developed to assess conventional oil and gas resources (fig. 2) (Schmoker and Charpentier, 2005; Schmoker and Klett, 2005). Conventional accumulations, as recognized by the USGS for the purpose of resource assessment, are defined by two geologic characteristics: (1) they occupy limited, discrete volumes of rock bounded by traps, seals, and downdip water contacts, and (2) they depend upon the buoyancy of oil or gas in water for their existence. In applying the USGS conventional assessment approach on gas hydrate resources, downhole log data from wells and three-dimensional, industry-acquired seismic data were analyzed, with the results showing that gas hydrates on the North Slope occupy discrete hydrocarbon reservoirs, most of which are bounded by faults and downdip water contacts (as discussed in the "Alaska North Slope Gas Hydrate Petroleum System" section).

The USGS conventional assessment methodology is built on the geologic elements used to define a Total Petroleum System (TPS), including hydrocarbon source rocks (sourcerock type and maturation and hydrocarbon generation and migration), reservoir rocks (sequence stratigraphy, petrophysical properties, and seismic attribute development), and hydrocarbon traps (trap formation and timing). In this approach, the subdivisions of a TPS, termed "assessment units" (AU), are the basic level of the assessment. In most cases, a TPS consists of all genetically related hydrocarbons generated from the same source rock. In the case of this assessment, each AU was defined mostly on the similarities of the gas hydrate-bearing rocks. Detailed framework studies in stratigraphy and structural geology and the analysis of petroleum geochemistry, combined with historical exploration results, were used to define three gas hydrate AUs in northern Alaska, as described later in the section "Northern Alaska Gas Hydrate Total Petroleum System and Assessment Units."

The USGS assessment methodology (fig. 2) also requires estimates of the number and sizes of undiscovered accumulations, for which the technically recoverable resources are then calculated by statistically combining the probability distributions of the estimated number and sizes of the undiscovered accumulations, along with associated risks. The techniques used to estimate the number and sizes of undiscovered gas hydrate accumulations in northern Alaska are discussed in the following sections of

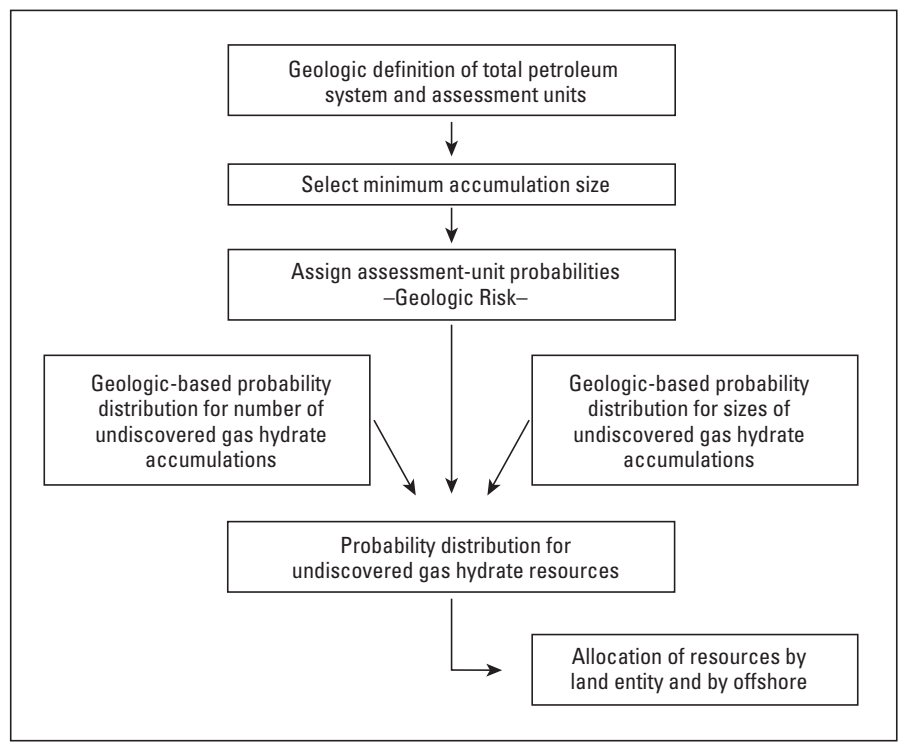

Figure 2. Flow diagram showing key steps in the USGS assessment model for undiscovered conventional oil and gas accumulations. Modified from Schmoker and Klett (2005). 
this report: "Undiscovered Gas Hydrate AccumulationsSizes of Accumulations" and "Undiscovered Gas Hydrate Accumulations-Number of Accumulations." Within the USGS assessment methodology, probabilistic estimates are given for the amount of technically recoverable resources in the hydrocarbon accumulations. In most cases the production histories from existing wells in the assessment unit or from analog settings are used to estimate the relative percent of hydrocarbon that will be recovered from an accumulation. For gas hydrates, however, there are no established production histories to draw upon. In this assessment, data from limited field testing and numerical production modeling were used to establish the expected production characteristics of gas hydrate-bearing reservoirs, as discussed in the section "Gas Hydrate Production Analysis."

For the purpose of the USGS assessment model, undiscovered petroleum is that which is postulated from geologic knowledge and theory to exist outside of known accumulations. For this gas assessment, it was decided to consider all of the gas hydrate accumulations on the Alaska North Slope as undiscovered because none of the welllog- and seismic-inferred gas hydrate accumulations have established production histories.

\section{Gas Hydrate Technical Review}

Gas hydrates are naturally occurring "ice-like" combinations of natural gas and water that have the potential to provide an immense resource of natural gas from the world's oceans and polar regions. Gas hydrates are known to be widespread in permafrost regions and beneath the sea in sediments of outer continental margins. It is generally accepted that the volume of natural gas contained in the world's gas hydrate accumulations greatly exceeds that of known gas reserves (Collett, 2002). There is also growing evidence that natural gas can be produced from gas hydrates with existing conventional oil and gas production technology (Anderson and others, 2008, Dallimore and others, 2008a, 2008b; Yamamoto and Dallimore, 2008; Moridis and others, 2009).

Gas hydrates are crystalline compounds that result from the three-dimensional stacking of "cages" of hydrogen-bonded water molecules. Generally, each cage can hold a single gas molecule. The empty cagework is unstable, and requires the presence of encapsulated gas molecules to stabilize the clathrate crystal. The compact nature of the hydrate structure makes for highly effective packing of gas. A volume of gas hydrate expands between 150- and 180-fold when released in gaseous form at standard pressure and temperature (14.696 pounds per square inch (psi), 68 ${ }^{\circ} \mathrm{F}$ ).

Clathrate hydrates can form in the presence of gas molecules over the size range of 4.8-9.0 angstroms. Three distinct structural types can form depending on the size of the largest guest molecules that can be included in the clathrate cage of water molecules. There are considerable complexities in the structure-size relation; however, methane and ethane individually form Structure I (sI) hydrate, but in certain combinations also form Structure II (sII) hydrate. Propane and isobutane form sII hydrate, either individually or in combination with ethane and methane. Normal-butane and neopentane form sII hydrate only when methane is present as well, and larger hydrocarbon molecules (C5-C9) form Structure $\mathrm{H}(\mathrm{sH})$ hydrate, again where methane is present.

On a macroscopic level, many of the mechanical properties of gas hydrates resemble those of ice because hydrates contain about 85 percent water on a molar basis. For a complete description of the structure and physical properties of gas hydrates, see the summary by Sloan and Koh (2008).

\section{Alaska North Slope Gas Hydrate Petroleum System}

In recent years, the concept of a gas hydrate petroleum system, similar to the concept that guides conventional oil and gas exploration, has gained acceptance (Collett and others, 2009). In a gas hydrate petroleum system, the individual factors that contribute to the formation of gas hydrate can be identified and assessed; the most important include

(1) gas hydrate pressure-temperature stability conditions, (2) suitable host sediment or "reservoir," (3) gas source, and (4) gas migration. In the following discussion, these geologic controls on the stability and formation of gas hydrate deposits in northern Alaska are reviewed and evaluated.

\section{4.a. Gas Hydrate Stability Conditions}

Gas hydrates exist under a limited range of temperature and pressure conditions, such that the depth and thickness of the zone of potential gas hydrate stability can be calculated given information on formation temperatures, pore-pressure gradients, and gas and formation water chemistry. Depicted in the temperature/depth plot in figure 3 are a series of subsurface temperature profiles from an onshore permafrost area and two laboratory-derived gas hydrate stability curves for different natural gases (modified from Holder and others, 1987). This gas hydrate phase diagram (fig. 3) illustrates how variations in formation temperature, pore-pressure, and gas composition can affect the thickness of the gas hydrate stability zone. In this example, the mean annual surface temperature is assumed to be $14^{\circ} \mathrm{F}\left(-10^{\circ} \mathrm{C}\right)$; and the depth to the base of permafrost $\left(32^{\circ} \mathrm{F} ; 0^{\circ} \mathrm{C}\right.$ isotherm) is varied for three example temperature profiles, at permafrost depths of 1,000 feet (ft) (305 meters (m)), 2,000 ft (610 m), and $3,000 \mathrm{ft}(914 \mathrm{~m})$. Below permafrost, three different example geothermal gradients of $2.19^{\circ} \mathrm{F} / 100 \mathrm{ft}\left(4.0^{\circ} \mathrm{C} / 100 \mathrm{~m}\right)$, $1.76^{\circ} \mathrm{F} / 100 \mathrm{ft}\left(3.2^{\circ} \mathrm{C} / 100 \mathrm{~m}\right)$, and $1.10^{\circ} \mathrm{F} / 100 \mathrm{ft}\left(2.0^{\circ} \mathrm{C} / 100 \mathrm{~m}\right)$ are used to project the sub-permafrost temperature profiles. 


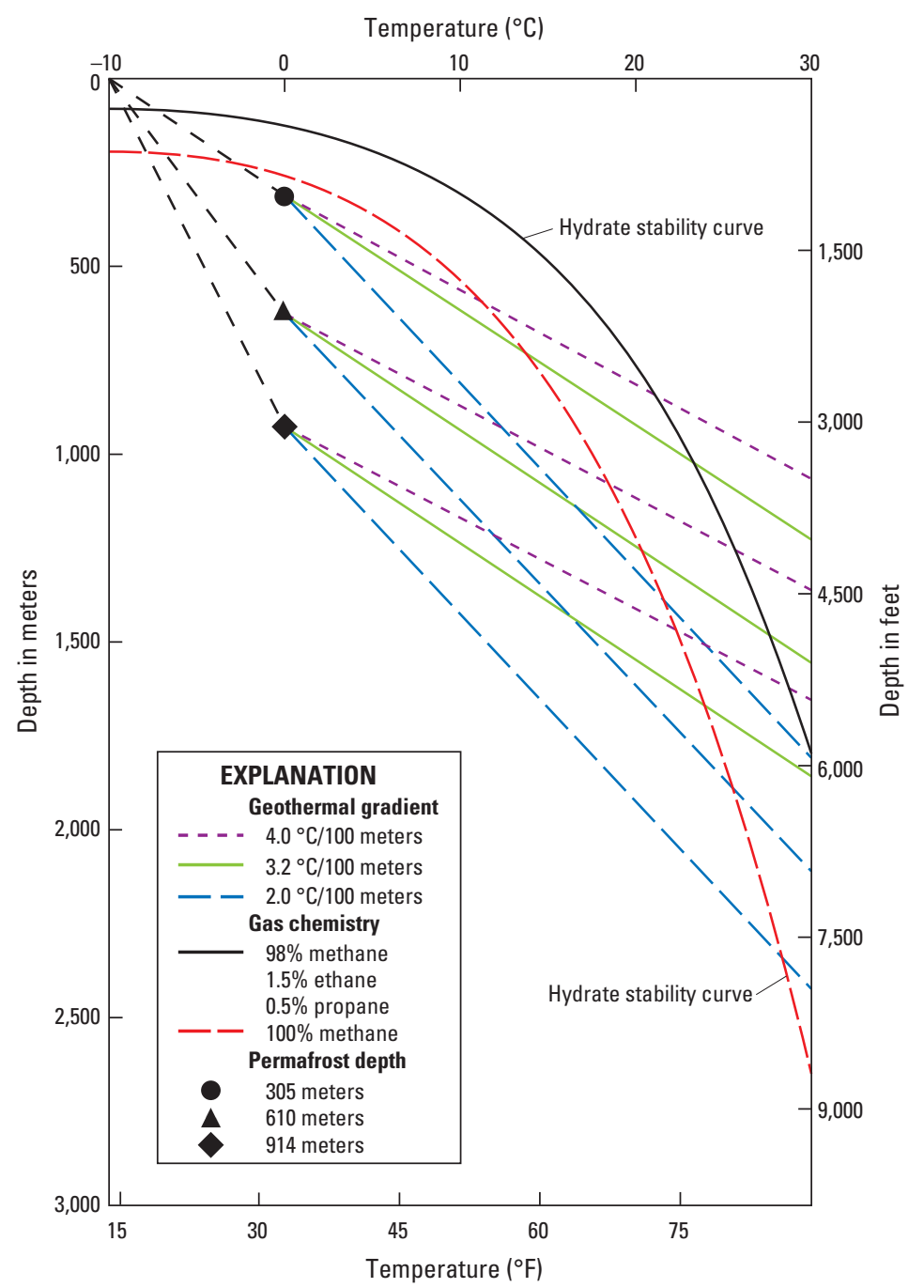

Figure 3. Gas hydrate phase diagram showing the depth and temperature conditions suitable for the formation of gas hydrate under various conditions of permafrost depth, geothermal gradient, gas chemistry, and a porepressure gradient of $0.433 \mathrm{psi} / \mathrm{ft}(9.795 \mathrm{kPa} / \mathrm{m})$. Modified from Holder and others (1987). (psi/ft, pounds per square inch per feet; $\mathrm{kPa} / \mathrm{m}$, kilopascals per meter)

The two gas hydrate stability curves represent gas hydrates with different gas chemistries: one with 100 percent methane hydrate, and the other with 98 percent methane, 1.5 percent ethane, and 0.5 percent propane. The phase diagram (fig. 3 ) is constructed assuming a hydrostatic pore-pressure gradient of 0.433 pounds per square inch per foot (psi/ft) (9.795 kilopascals per meter $(\mathrm{kPa} / \mathrm{m})$ ).

The zone of potential gas hydrate stability in the phase diagram (fig. 3) lies within the depths between the two intersections of the geothermal gradient and the gas hydrate stability curve. For example, in figure 3 , the temperature profile projected to an assumed permafrost base of 2,000 $\mathrm{ft}(610 \mathrm{~m})$ intersects the 100-percent methane-hydrate stability curve at about $656 \mathrm{ft}(200 \mathrm{~m})$, thus marking the upper boundary of the methane-hydrate stability zone. A geothermal gradient of $2.19^{\circ} \mathrm{F} / 100 \mathrm{ft}\left(4.0^{\circ} \mathrm{C} / 100 \mathrm{~m}\right)$ projected from the base of permafrost at 2,000 $\mathrm{ft}(610 \mathrm{~m})$ intersects the 100 -percent methane-hydrate stability curve at about 3,609 ft $(1,100 \mathrm{~m})$; thus, the zone of potential methane-hydrate stability is approximately $2,953 \mathrm{ft}(900 \mathrm{~m})$ thick. However, if permafrost is extended to a depth of $3,000 \mathrm{ft}(914 \mathrm{~m})$ and if the geothermal gradient below permafrost is $1.10^{\circ} \mathrm{F} / 100 \mathrm{ft}\left(2.0^{\circ} \mathrm{C} / 100 \mathrm{~m}\right)$, the zone of potential methane-hydrate stability would be approximately $6,890 \mathrm{ft}(2,100 \mathrm{~m})$ thick.

Most gas hydrate stability studies assume a hydrostatic pore-pressure gradient (see Collett, 2002). Pore-pressure gradients greater than hydrostatic conditions correspond to higher pore-pressures with depth and a thicker gas hydrate stability zone, whereas a pore-pressure gradient less than hydrostatic corresponds to a thinner gas hydrate stability zone. 
The gas hydrate stability curves in figure 3 were obtained from laboratory data published by Holder and others (1987). The addition of 1.5 percent ethane and 0.5 percent propane to the pure methane gas system shifts the stability curve to the right, thus deepening the zone of potential gas hydrate stability. It is well known that dissolved salt can depress the freezing-point of water. Where present in a gas hydrate system, salt (such as $\mathrm{NaCl}$ ) also lowers the temperature at which gas hydrates form.

Collett and others (1988) and Collett (1993) included extensive analyses of gas hydrate stability conditions in northern Alaska. In support of the present assessment, Lee and others (2008) also used log data from wells drilled since these earlier studies for updating the permafrost (fig. 4) and methane hydrate stability maps (fig. $5 A-C$; table 1 ) in northern Alaska as reviewed below.

On the North Slope, the subsurface temperature data needed to assess the distribution of the gas hydrate stability zone are provided by high-resolution, equilibrated wellbore surveys in 46 wells and from well-log estimates of the base of ice-bearing permafrost in 102 other wells (Collett, 1993). Beginning in 1958, a series of 46 North Slope wells, considered to be in or near thermal equilibrium, have been surveyed with high-resolution temperature devices (Lachenbruch and others, 1987; Lee and others, 2008). Geothermal gradients, which are needed to predict the depth and thickness of the gas hydrate stability zone, can be interpreted directly from these equilibrated temperature profiles. However, specific evaluation of subsurface temperatures at any one particular site on the North Slope is subject to error because of the vastness of the region and the limited number of equilibrated well-bore temperature surveys. To augment the limited North Slope temperature database, Collett and others (1988) developed a new method to evaluate local geothermal gradients.

In this method, well-log picks for the base of the icebearing permafrost from 102 wells (fig. 4) were combined with regional temperature constants derived from the highresolution surveys to extrapolate temperature data. The comparison of geothermal gradients calculated from the highresolution temperature surveys and projected from known ice-bearing permafrost depths are similar over most of the North Slope, with gradient values in the ice-bearing sequence ranging from about $0.82^{\circ} \mathrm{F} / 100 \mathrm{ft}\left(1.5^{\circ} \mathrm{C} / 100 \mathrm{~m}\right)$ in the Prudhoe Bay area to about $2.47^{\circ} \mathrm{F} / 100 \mathrm{ft}\left(4.5^{\circ} \mathrm{C} / 100 \mathrm{~m}\right)$ in the National Petroleum Reserve in Alaska (NPRA). The calculated and projected geothermal gradients from below the ice-bearing sequence range from about $0.88^{\circ} \mathrm{F} / 100 \mathrm{ft}\left(1.6^{\circ} \mathrm{C} / 100 \mathrm{~m}\right)$ to about $2.85^{\circ} \mathrm{F} / 100 \mathrm{ft}\left(5.2^{\circ} \mathrm{C} / 100 \mathrm{~m}\right)$.

Subsurface pore-pressure gradients calculated from shut-in pressures recorded during drill-stem testing in wells from the North Slope range from 0.41 to $0.50 \mathrm{psi} / \mathrm{ft}(9.3$ to $11.2 \mathrm{kPa} / \mathrm{m}$ ), with an average gradient of $0.43 \mathrm{psi} / \mathrm{ft}$ $(9.7 \mathrm{kPa} / \mathrm{m})$, near hydrostatic (Collett and others, 1988). To further evaluate pore-pressure conditions, Collett (1993) used gamma ray and density well logs to study overburden compaction profiles. Within the near-surface $(0-5,000 \mathrm{ft}$; 0-1,524 m) sediments of the North Slope, no significant porepressure discontinuities were observed. Thus, a hydrostatic pore-pressure gradient $(0.433 \mathrm{psi} / \mathrm{ft} ; 9.795 \mathrm{kPa} / \mathrm{m})$ is generally assumed when considering gas hydrate stability conditions in northern Alaska.

Most of the previous studies of gas hydrate stability conditions in northern Alaska have assumed a pure methane chemistry for the gas being included in the gas hydrate structure (Collett, 1995). The analysis of mud-log gaschromatographic data from industry exploratory wells generally indicates that methane is the dominant hydrocarbon gas in the near-surface $(0-5,000 \mathrm{ft})$ sedimentary rocks of the North Slope (Collett and others, 1988). Analysis of gas evolved from recovered cored gas hydrate-bearing sedimentary sections in the Prudhoe Bay and Milne Point fields confirm that the in-situ gas hydrates are composed mostly of methane in this portion of the North Slope (Collett, 1993; Lorenson and others, 2011).

Pore-water salinity data within the near-surface sediments of the North Slope are available from petroleum production tests, water samples from cores within and below permafrost, and spontaneous potential well-log calculations. These data indicate that the pore-water salinities within the sands both above and below the ice-bearing permafrost section are low, ranging from $<1.0$ parts per thousand (ppt) to as high as $19 \mathrm{ppt}$ (Collett and others, 1988). Analysis of core-derived pore waters from the Mount Elbert well (discussed later in this report) also confirm the presence of low-salinity pore water, with an average background concentration around $5.0 \mathrm{ppt}$. The updated gas hydrate stability calculations in Lee and others (2008) for northern Alaska were made assuming a pore-water salinity of $5.0 \mathrm{ppt}$.

The methane-hydrate stability zone in northern Alaska, as mapped in figures $5 A-C$ (modified from Collett, 1993), covers most of the North Slope. The offshore extent of the gas hydrate stability zone is not well established. Geologic studies (for example Molochushkin, 1978) and thermal modeling of subsea conditions (Osterkamp and Fei, 1993) indicate that permafrost and gas hydrate may exist within the continental shelf of the Arctic Ocean. Subaerial emergence of portions of the Arctic continental shelf to current water depths of roughly $400 \mathrm{ft}$ (roughly $122 \mathrm{~m}$ ) (Bard and Fairbanks, 1990) during repeated Pleistocene glaciations subjected the exposed shelf to temperature conditions favorable to the formation of permafrost and gas hydrate. Thus, it is speculated that "relict" permafrost and gas hydrate may exist on the continental shelf of the Arctic Ocean to present water depths of $400 \mathrm{ft}$ (roughly $122 \mathrm{~m}$ ). For this assessment, we assumed the model-derived predictions of permafrost and gas hydrate stability conditions to be accurate and that the offshore limit of the nearshore permafrost-associated gas hydrate stability conditions as depicted in figures $5 A-C$ for the most part corresponds to the $400-\mathrm{ft}$ (roughly $122 \mathrm{~m}$ ) bathymetric contour. 


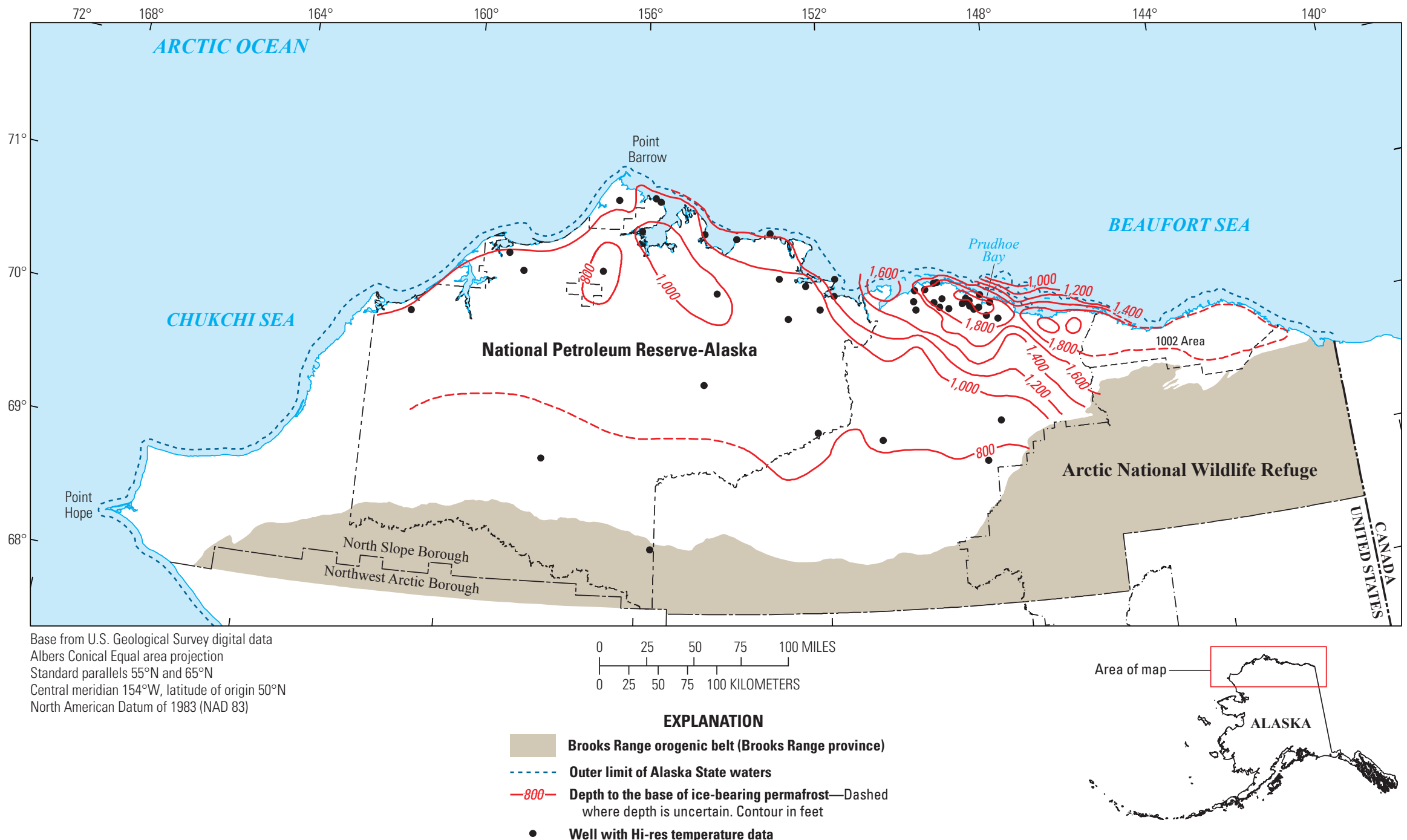

Figure 4. Map showing the depth to base of permafrost on the Alaska North Slope as determined from equilibrated well-bore temperature surveys in 46 wells (table 1; Lee and others, 2008). Well-log estimates for the base of ice-bearing permafrost in 102 other wells (Collett, 1993) were also used to draw the map contours. Contours in feet (ft). (NPRA, Natural Petroleum Reserve in Alaska; ANWR, Alaska National Wildlife Refuge) 


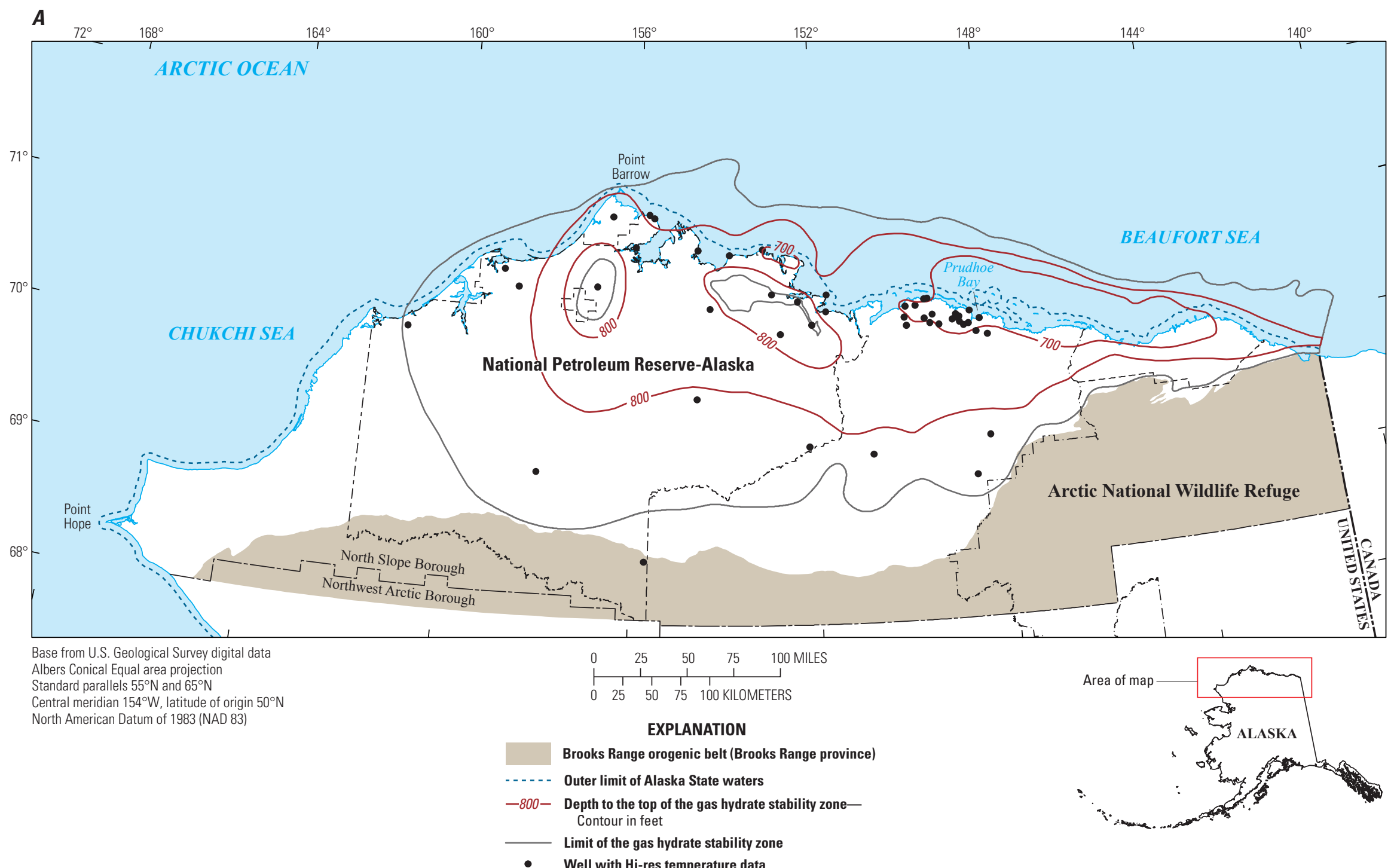

Figure 5. Maps of the Alaska North Slope gas hydrate stability zone (modified from Collett and others, 1988): $A$, depth to the top of the hydrate stability zone; $B$, depth to base of the hydrate stability zone; $C$, thickness of the hydrate stability zone. Contours in feet (ft). (NPRA, Natural Petroleum Reserve in Alaska; ANWR, Alaska National Wildlife Refuge) 
B

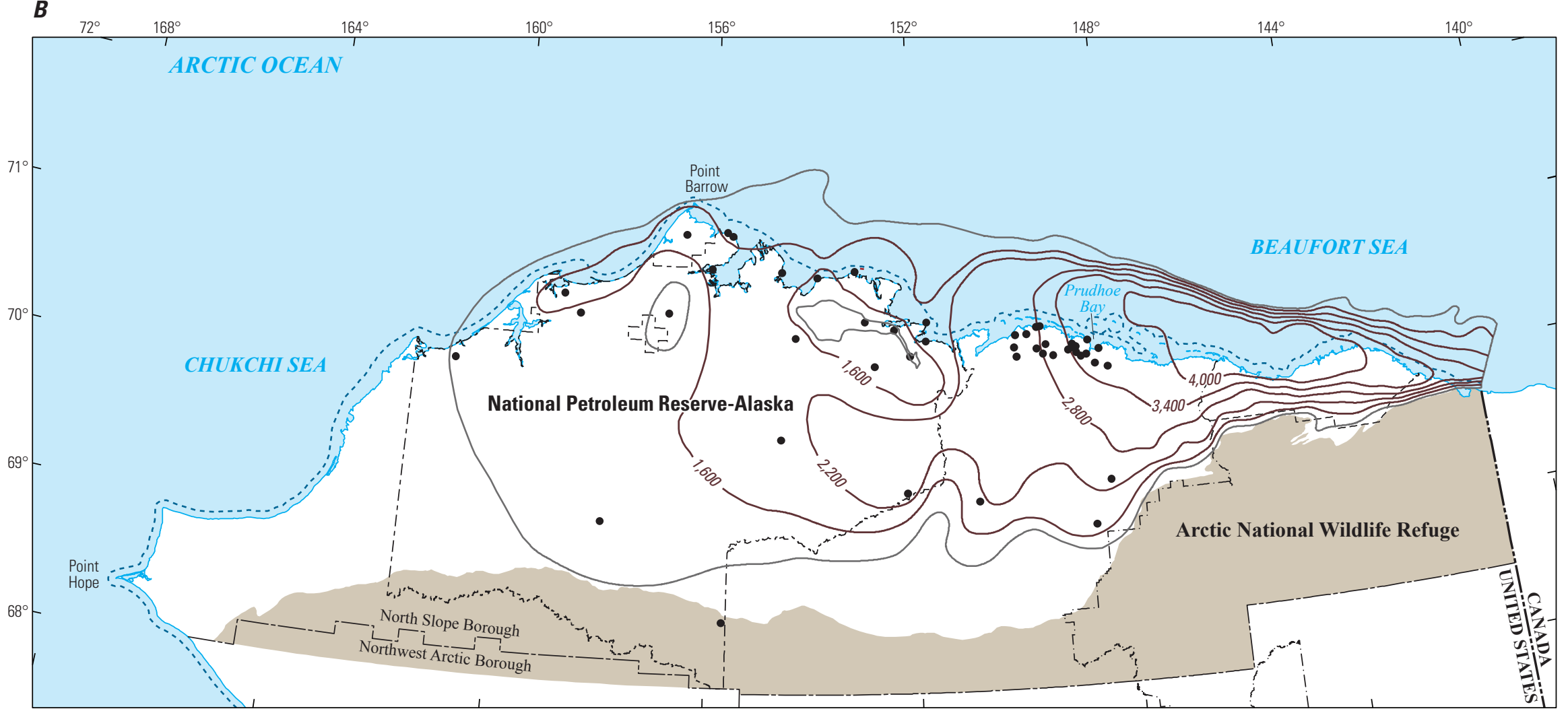

Base from U.S. Geological Survey digital data Albers Conical Equal area projection

Central meridian $154^{\circ} \mathrm{W}$, latitude of origin $50^{\circ} \mathrm{N}$ North American Datum of 1983 (NAD 83)

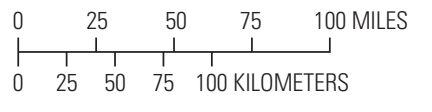

EXPLANATION

Brooks Range orogenic belt (Brooks Range province) Outer limit of Alaska State waters

$-1,600$ - Depth to the base of the gas hydrate stability zoneContour in feet

Limit of the gas hydrate stability zone

- Well with Hi-res temperature data

Figure 5. Maps of the Alaska North Slope gas hydrate stability zone (modified from Collett and others, 1988): $A$, depth to the top of the hydrate stability zone; $B$, depth to base of the hydrate stability zone; $\mathcal{C}$, thickness of the hydrate stability zone. Contours in feet (ft). (NPRA, Natural Petroleum Reserve in Alaska; ANWR, Alaska National Wildlife Refuge)—Continued 


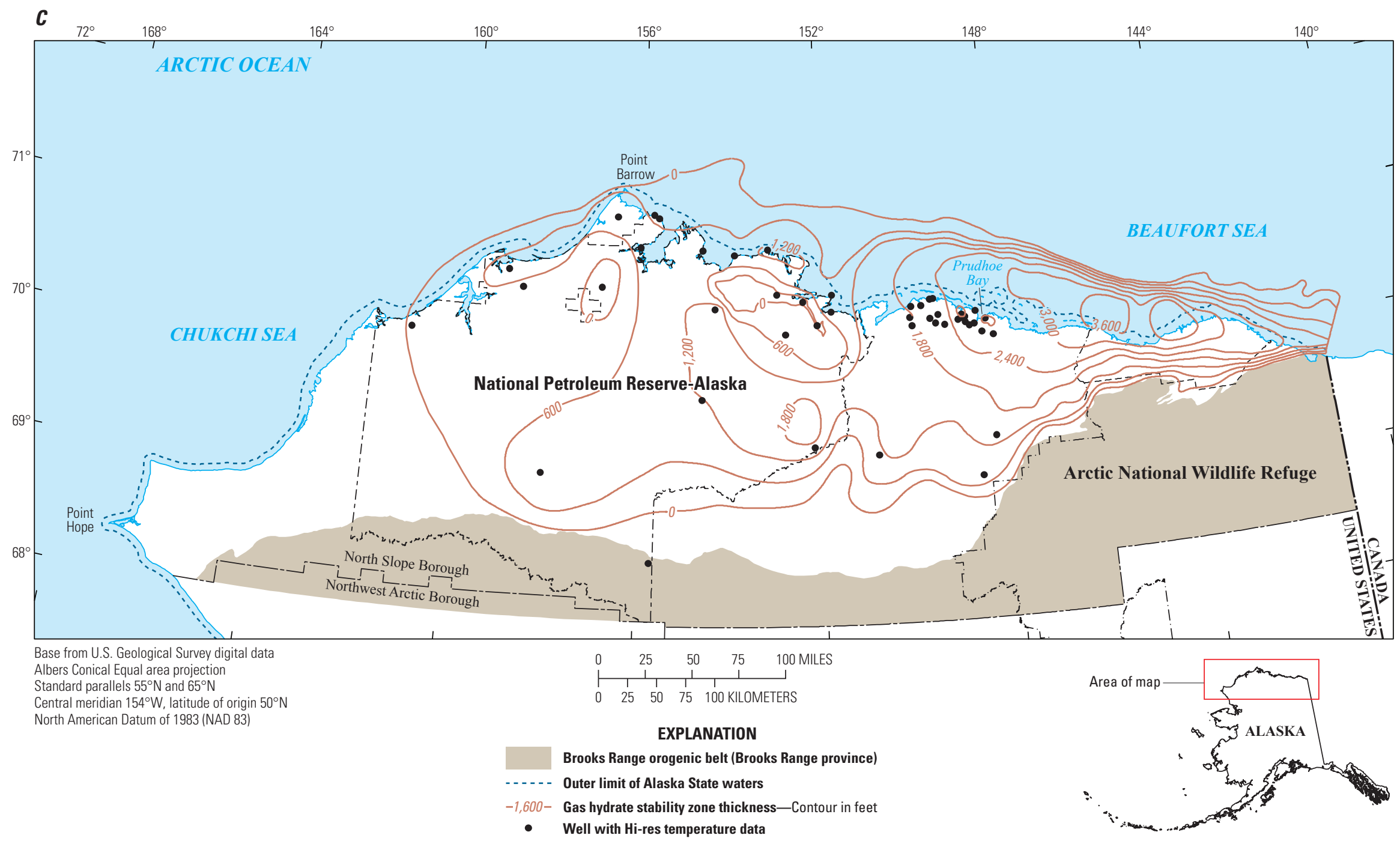

Figure 5. Maps of the Alaska North Slope gas hydrate stability zone (modified from Collett and others, 1988): $A$, depth to the top of the hydrate stability zone; $B$, depth to base of the hydrate stability zone; $\mathcal{C}$, thickness of the hydrate stability zone. Contours in feet (ft). (NPRA, Natural Petroleum Reserve in Alaska; ANWR, Alaska National Wildlife Refuge)—Continued 
Table 1. List of Alaska North Slope wells with equilibrated borehole temperature surveys along with the estimated depth of the base of permafrost ( $0^{\circ} \mathrm{C}$ ) and the depth to the top (THSZ) and base (BHSZ) of the gas hydrate stability zone. Also listed is the estimated thickness (isopach) of the gas hydrate stability zone (HSZ) (modified from Lee and others, 2008).

[API, American Petroleum Institute; m, meters; ft, feet]

\begin{tabular}{|c|c|c|c|c|c|c|c|c|c|c|c|}
\hline API & Common well name & Latitude & Longitude & $\begin{array}{c}\text { Depth }(\mathrm{m}) \\
\text { to } 0^{\circ} \mathrm{C}\end{array}$ & $\begin{array}{c}\text { Depth }(\mathrm{ft}) \\
\text { to } 0^{\circ} \mathrm{C}\end{array}$ & $\begin{array}{c}\text { Depth (m) } \\
\text { to THSZ }\end{array}$ & $\begin{array}{l}\text { Depth (ft) } \\
\text { to THSZ }\end{array}$ & $\begin{array}{c}\text { Depth (m) } \\
\text { to BHSZ }\end{array}$ & $\begin{array}{l}\text { Depth (ft) } \\
\text { to BHSZ }\end{array}$ & $\begin{array}{c}\text { Thickness (m) } \\
\text { HSZ }\end{array}$ & $\begin{array}{c}\text { Thickness (ft) } \\
\text { HSZ }\end{array}$ \\
\hline 50301200010000 & US TUNALIK \#1 & 70.2062 & 161.0687 & 270 & 886 & 258 & 845 & 320 & 1,050 & 62 & 204 \\
\hline 50301200020000 & US PEARD \#1 & 70.7156 & 158.9999 & 300 & 984 & 248 & 814 & 557 & 1,827 & 309 & 1,014 \\
\hline 50163200020000 & HU KUGRUA \#1 & 70.5866 & 158.6617 & 270 & 886 & 259 & 849 & 390 & 1,278 & 131 & 429 \\
\hline 50163200010000 & US SO MEADE \#1 & 70.6147 & 156.8834 & 200 & 656 & - & - & - & - & - & - \\
\hline 50023100110000 & US SO BARROW \#3 & 71.1652 & 156.5811 & 380 & 1,247 & 232 & 761 & 578 & 1,896 & 346 & 1,135 \\
\hline 50163200030000 & US KUYANAK \#1 & 70.9314 & 156.0368 & 320 & 1,050 & 233 & 763 & 500 & 1,640 & 267 & 877 \\
\hline 50023200180000 & US TULAGEAK 1 & 71.1885 & 155.7329 & 290 & 951 & 250 & 819 & 388 & 1,272 & 138 & 453 \\
\hline 50023200140000 & US WEST DEASE \#1 & 71.1594 & 155.6296 & 270 & 886 & 257 & 842 & 352 & 1,155 & 96 & 313 \\
\hline 50279200050000 & US E SIMPSON 1 & 70.9178 & 154.6180 & 360 & 1,181 & 228 & 748 & 556 & 1,824 & 328 & 1,076 \\
\hline 50279200040000 & HU IKPIKPUK 1 & 70.4555 & 154.3322 & 330 & 1,083 & 243 & 796 & 652 & 2,139 & 409 & 1,343 \\
\hline 50279200020000 & HU DREW POINT 1 & 70.8794 & 153.8997 & 320 & 1,050 & 232 & 761 & 460 & 1,509 & 228 & 748 \\
\hline 50279200060000 & US J W DALTON 1 & 70.9209 & 153.1380 & 400 & 1,312 & 213 & 700 & 604 & 1,982 & 391 & 1,282 \\
\hline 50103200060000 & HU E TESHEKPUK 1 & 70.5700 & 152.9447 & 250 & 820 & - & - & - & - & - & - \\
\hline 50103200170000 & US NORTH INIGOK 1 & 70.2576 & 152.7660 & 275 & 902 & 258 & 845 & 380 & 1,247 & 122 & 402 \\
\hline 50103200110000 & US NORTH KALIKPIK 1 & 70.5092 & 152.3668 & 210 & 689 & - & - & - & - & - & - \\
\hline 50103200090000 & HU WEST FISH CREEK 1 & 70.3267 & 152.0597 & 260 & 853 & - & - & - & - & - & - \\
\hline 50103200070000 & HU S HARRISON BAY 1 & 70.4245 & 151.7310 & 380 & 1,247 & 225 & 737 & 530 & 1,739 & 305 & 1,002 \\
\hline 50103200080000 & HU ATIGARU PT 1 & 70.5561 & 151.7160 & 400 & 1,312 & 217 & 711 & 541 & 1,775 & 324 & 1,064 \\
\hline 50029202750000 & WEST SAK 11 & 70.3569 & 149.9908 & 465 & 1,526 & 216 & 709 & 747 & 2,449 & 530 & 1,740 \\
\hline 50029204190000 & SO WEST SAK 14 & 70.2935 & 149.9515 & 465 & 1,526 & 215 & 705 & 741 & 2,431 & 526 & 1,726 \\
\hline 50029205410000 & WEST SAK 16 & 70.4433 & 149.9483 & 535 & 1,755 & 212 & 694 & 845 & 2,772 & 633 & 2,078 \\
\hline 50029205420000 & SO WEST SAK 17 & 70.4463 & 149.7237 & 550 & 1,804 & 210 & 689 & 850 & 2,789 & 640 & 2,100 \\
\hline 50029200900000 & AR WEST SAK RIVER ST 1 & 70.3397 & 149.5372 & 550 & 1,804 & 212 & 694 & 800 & 2,625 & 588 & 1,930 \\
\hline 50029215040000 & MPU C-19 & 70.4915 & 149.5245 & 525 & 1,722 & 215 & 705 & 850 & 2,789 & 635 & 2,083 \\
\hline 50029209000000 & MPU D-2 & 70.4905 & 149.4526 & 560 & 1,837 & 216 & 709 & 874 & 2,867 & 658 & 2,159 \\
\hline 50029205730000 & MO KUPARUK 1 & 70.3020 & 149.4169 & 570 & 1,870 & 215 & 705 & 857 & 2,812 & 642 & 2,106 \\
\hline 50029200130000 & AT NW EILEEN ST 1 & 70.3659 & 149.3559 & 530 & 1,739 & 207 & 679 & 860 & 2,822 & 653 & 2,142 \\
\hline 50029201990000 & AT HIGHLAND ST 1 & 70.2869 & 149.2181 & 575 & 1,886 & 210 & 689 & 908 & 2,979 & 698 & 2,290 \\
\hline 50029200790000 & PUT RIVER N-1: 08-11-13 & 70.3186 & 148.9097 & 615 & 2,018 & 209 & 687 & 1,019 & 3,343 & 810 & 2,656 \\
\hline 50029200250000 & PUT RIVER J-3:04-11-13 & 70.3300 & 148.8467 & 635 & 2,083 & 209 & 684 & 1,063 & 3,488 & 855 & 2,803 \\
\hline 50029200470000 & PUT RIVER 33-12-13 & 70.3561 & 148.8350 & 650 & 2,133 & 206 & 674 & 1,180 & 3,871 & 975 & 3,197 \\
\hline 50029200840000 & PUT RIVER F-2-11-11-13 & 70.3347 & 148.7669 & 630 & 2,067 & 216 & 709 & 1,048 & 3,438 & 832 & 2,729 \\
\hline 50029200850000 & PUT RIVER F-3-12-11-13 & 70.3353 & 148.7644 & 630 & 2,067 & 229 & 752 & 1,105 & 3,625 & 876 & 2,873 \\
\hline 50029200540000 & PUT RIVER 23-11-13 & 70.2944 & 148.7525 & 540 & 1,772 & 210 & 688 & 1,065 & 3,494 & 855 & 2,806 \\
\hline 50029200590000 & PUT RIVER 31-11-14 & 70.2683 & 148.6733 & 640 & 2,100 & 210 & 687 & 1,085 & 3,560 & 876 & 2,872 \\
\hline 50029200060000 & PUT RIVER 27-11-14 & 70.2783 & 148.5656 & 615 & 2,018 & 211 & 693 & 1,050 & 3,445 & 839 & 2,752 \\
\hline 50029200490000 & NORTH PRUDHOE BAY STATE 1 & 70.3764 & 148.5250 & 596 & 1,955 & 206 & 676 & 1,057 & 3,468 & 851 & 2,792 \\
\hline 50029200350000 & PUT RIVER 19-10-15 & 70.2117 & 148.4125 & 585 & 1,919 & 218 & 715 & 1,048 & 3,438 & 830 & 2,723 \\
\hline 50029201330000 & EAST BAY STATE \# 1 & 70.3106 & 148.3161 & 620 & 2,034 & 211 & 691 & 1,130 & 3,707 & 919 & 3,016 \\
\hline 50029200300000 & SAG DELTA 31-10-16 & 70.1822 & 148.1581 & 590 & 1,936 & 224 & 734 & 1,010 & 3,314 & 786 & 2,580 \\
\hline 50155200010000 & US AWUNA\#1 & 69.1532 & 158.0214 & 236 & 774 & 264 & 865 & 468 & 1,535 & 204 & 670 \\
\hline 50137200030000 & US LISBURNE \#1 & 68.4863 & 155.6935 & 264 & 866 & 264 & 866 & 783 & 2,569 & 519 & 1,703 \\
\hline 50119200010000 & US KOLUKTAK 1 & 69.7524 & 154.6111 & 280 & 919 & 257 & 843 & 540 & 1,772 & 283 & 928 \\
\hline 50287200070000 & US SEABEE 1 & 69.3801 & 152.1753 & 300 & 984 & 258 & 845 & 1,070 & 3,510 & 812 & 2,665 \\
\hline 50287100180000 & BP KUPARUK 1 & 69.3044 & 150.8093 & 265 & 869 & 262 & 860 & 595 & 1,952 & 333 & 1,093 \\
\hline 50223200110000 & FO LUPINE 1 & 69.1009 & 148.6193 & 220 & 722 & 337 & 1,106 & 660 & 2,165 & 323 & 1,060 \\
\hline 50223200080000 & MO ECHOOKA 1 & 69.4002 & 148.2680 & 265 & 869 & 263 & 864 & 787 & 2,582 & 524 & 1,719 \\
\hline
\end{tabular}




\section{4.b. Reservoir Rocks}

The study of gas hydrate samples indicates that the physical nature of in-situ gas hydrates is highly variable (reviewed by Sloan and Koh, 2008). Gas hydrates are observed as (1) occupying pores of coarse-grained sediment; (2) nodules disseminated within fine-grained sediment; (3) a solid substance, filling fractures; or (4) a massive unit composed mainly of solid gas hydrate with minor amounts of sediment. However, most gas hydrate field expeditions have shown that the occurrence of concentrated gas hydrate is mostly controlled by the presence of fractures and (or) coarse-grained sediments in which gas hydrate fills fractures or is disseminated in the pores of sand-rich reservoirs (Collett, 1993; Dallimore and Collett, 2005; Riedel and others, 2006; Collett and others, 2008a, 2008b; Park and others, 2008; Yang and others, 2008). Torres and others, (2008) concluded that hydrate accumulates preferentially in coarse-grained sediments because lower capillary pressures in these sediments permit the migration of gas and nucleation of hydrate. The growth of gas hydrate in clay-rich sediments, however, is less understood. Because high concentrations of gas hydrates in arctic permafrost regions are in sanddominated reservoirs, such lithologic units have been the focus of gas hydrate exploration and production studies in northern Alaska. Production testing and modeling have also shown that concentrated gas hydrate in sand reservoirs is conducive to existing well-based production technologies (Anderson and others, 2008; Dallimore and others, 2008a, 2008b; Moridis and others, 2009; Yamamoto and Dallimore, 2008).

The northern Alaska oil and gas province extends 600 miles (mi) from the Chukchi Sea on the west to the Canadian border on the east (figs. $1 A-B$ ); maximum width is about $200 \mathrm{mi}$ and total area is about 54,000 square miles $\left(\mathrm{mi}^{2}\right)$. The geology and petroleum geochemistry of rocks on the North Slope of Alaska are described in considerable detail in a number of publications (Lerand, 1973; Grantz and others, 1975; Carman and Hardwick, 1983; Bird and Magoon, 1987; Gryc, 1988; Bird, 1998; Mull and others, 2003). The sedimentary rocks of the North Slope can be conveniently grouped into four sequences representing major episodes in the tectonic development of the region and, to a degree, reflecting its lithologic character. Defined on the basis of source area, these sequences (proposed by Lerand (1973) and applied to northern Alaska by Grantz and others (1975) and modified by Hubbard and others (1987)) are, in ascending order, the Franklinian (Cambrian through Devonian), the Ellesmerian (Mississippian to Jurassic), Beaufortian (Jurassic through Lower Cretaceous), and the Brookian (Cretaceous to Holocene). All of the known and inferred gas hydrate occurrences on the North Slope are in Cretaceous and Tertiary reservoirs of the Brookian sequence (fig. 6), which are the focus of the following discussions on the geologic history of northern Alaska.
Before the recent completion of coring and downholelogging operations in the BPXA-DOE-USGS Mount Elbert Gas Hydrate Stratigraphic Test Well in the Milne Point field (Hunter and others, 2011), the only direct confirmation of gas hydrate on the North Slope was obtained in 1972 with data from the ARCO-Exxon Northwest Eileen State-2 well, located in the northwest part of the Prudhoe Bay field. Studies of pressurized core samples, downhole logs, and the results of formation-production testing confirmed the presence of three gas hydrate-bearing stratigraphic units in the Northwest Eileen State-2 well (fig. 7) (Collett, 1993). The gas hydrate-bearing core in the Northwest Eileen State-2 well was recovered from a depth of 2,156 ft $(657 \mathrm{~m})$. The well was drilled with chilled drilling muds in an attempt to reduce thawing of permafrost and decomposition of the in-situ gas hydrate that might exist. A pressure-core system was also used to recover core samples at near in-situ conditions in order to reduce core disturbance attributed to gas hydrate dissociation. The presence of gas hydrate in the recovered core was confirmed by a pressure test as described by Hunt (1979, p. 167).

The confirmed gas hydrate occurrence in the Northwest Eileen State-2 well provided an ideal starting point for the development of gas hydrate well-log evaluation techniques (fig. 7). Numerous studies since this early work, including Collett (1993), have shown that in most cases only two welllogging devices are used to identify potential gas hydrates: they are the electrical resistivity and acoustic transit-time logs. For the most part, a gas hydrate-bearing sand reservoir is characterized by relatively high electrical resistivities and rapid acoustic transit times in comparison to water-saturated sands. However, resistivity and acoustic logs behave similarly within a sedimentary section that is saturated with either gas hydrate or ice. Hence, gas shows on the mud log produced from decomposing hydrate generally provide the only means of conclusively differentiating a gas hydrate from ice in Arctic permafrost regions.

Collett (1993) examined well-log data from 445 wells for evidence of gas hydrate based on the well-log responses observed in the Northwest Eileen State-2 well. Most of the wells were located in the greater Prudhoe Bay area; however, all wells in NPRA and most of the exploratory wells to the south and east of Prudhoe Bay were reviewed. Since this earlier work, Lee and others (2008) and Inks and others (2009) examined the well-log data from about 200 additional exploratory and development wells for the presence of gas hydrate. These well-log-based studies revealed the occurrence of two large gas hydrate accumulations, which have been named the Eileen and Tarn gas hydrate accumulations.

The Eileen gas hydrate accumulation was first described by Collett (1993) as six laterally continuous gas hydratebearing sandstone units, each of which has been assigned a reference letter $(A-F$, in ascending order; fig. 8). Many of the wells that penetrated the Eileen accumulation have multiple gas hydrate-bearing units, with individual units ranging from 10 to $100 \mathrm{ft}$ ( 3 to $30 \mathrm{~m}$ ) thick. All of the wells are geographically restricted to the area overlying the eastern 
West

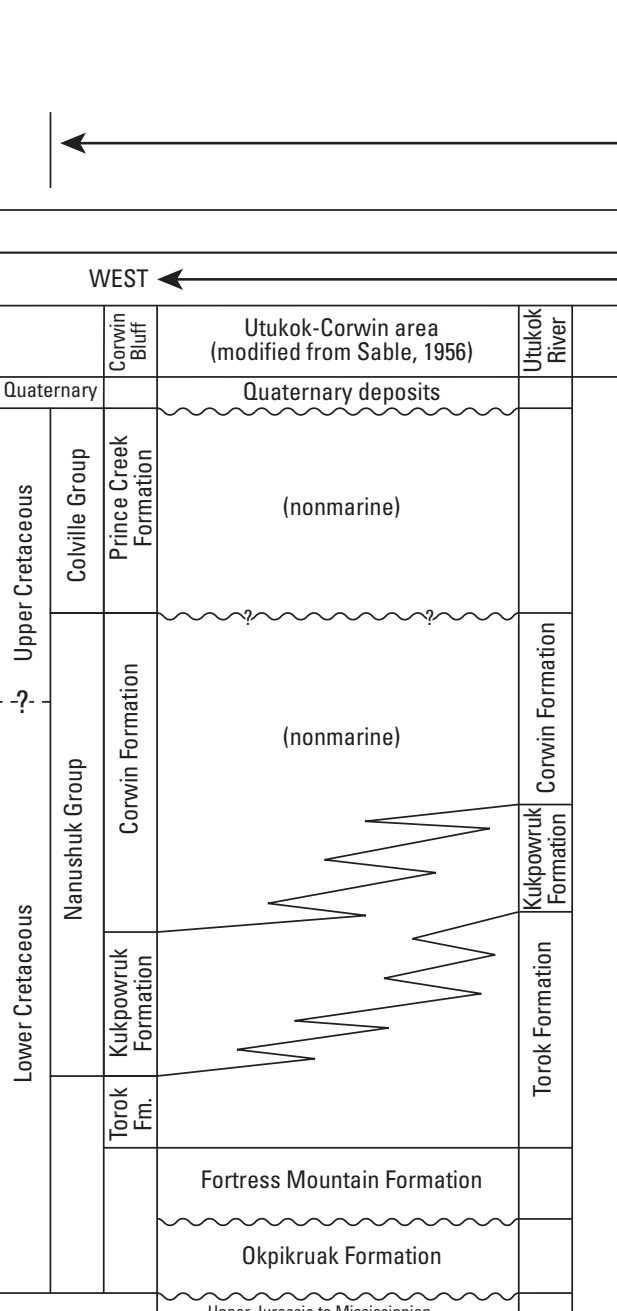

Previous nomenclature

Chapman, Detterman, and Mangus, 1964

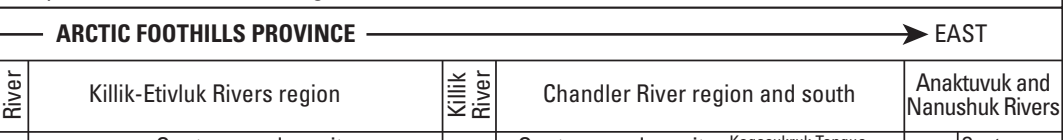

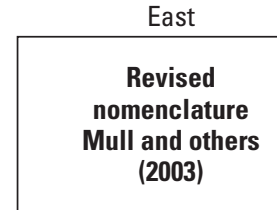

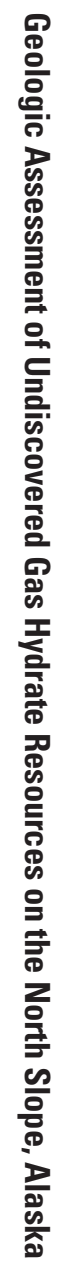

Upper Jurassic to Mississippian

Formatio

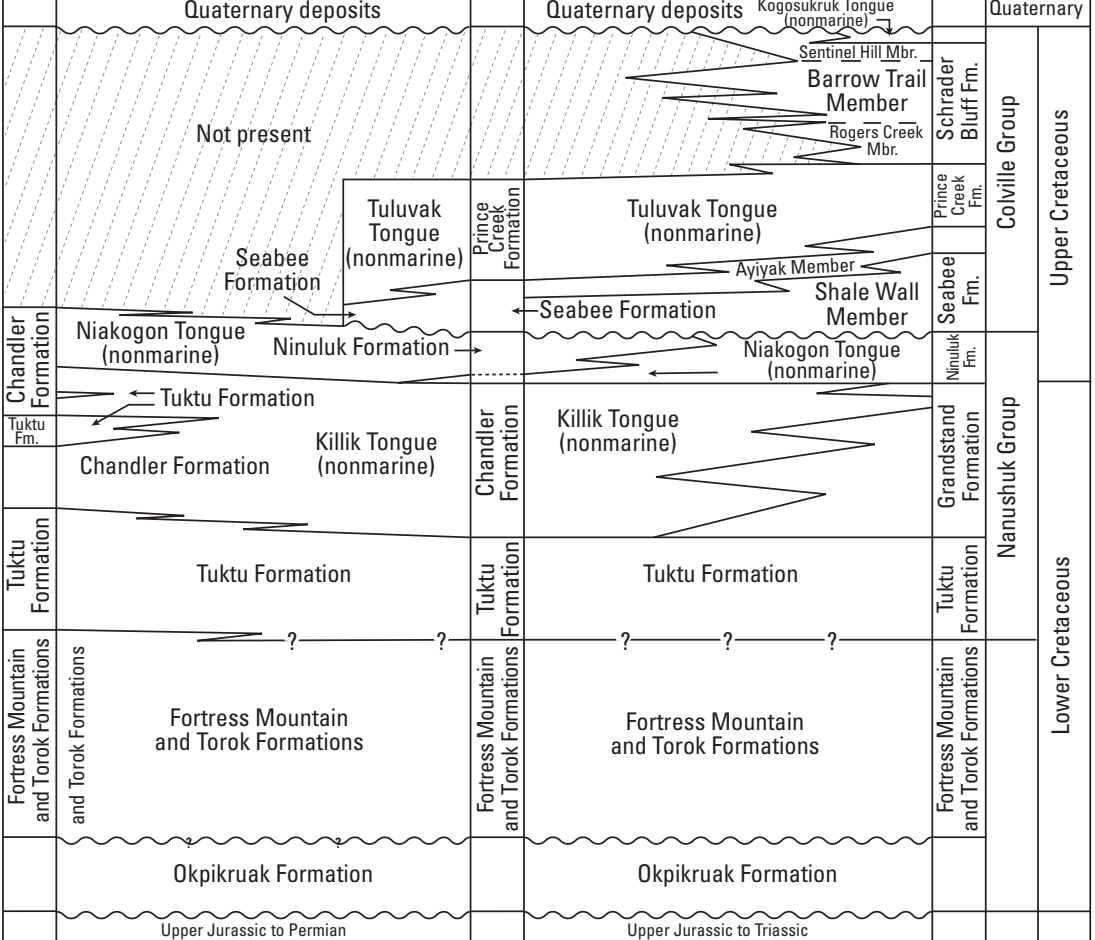

EXPLANATION

Formation assessed for gas hydrates

Figure 6. Lithostratigraphic chart illustrating the relations between former and revised nomenclature of Mull and others (2003) for the Alaska North Slope. Stratigraphic columns summarize the lateral variations in previous stratigraphic nomenclature for Tertiary and Cretaceous strata from west to east across the western and central foothills of the Brooks Range, as presented by Chapman and others (1964) and modified from Mull and others (2003). 


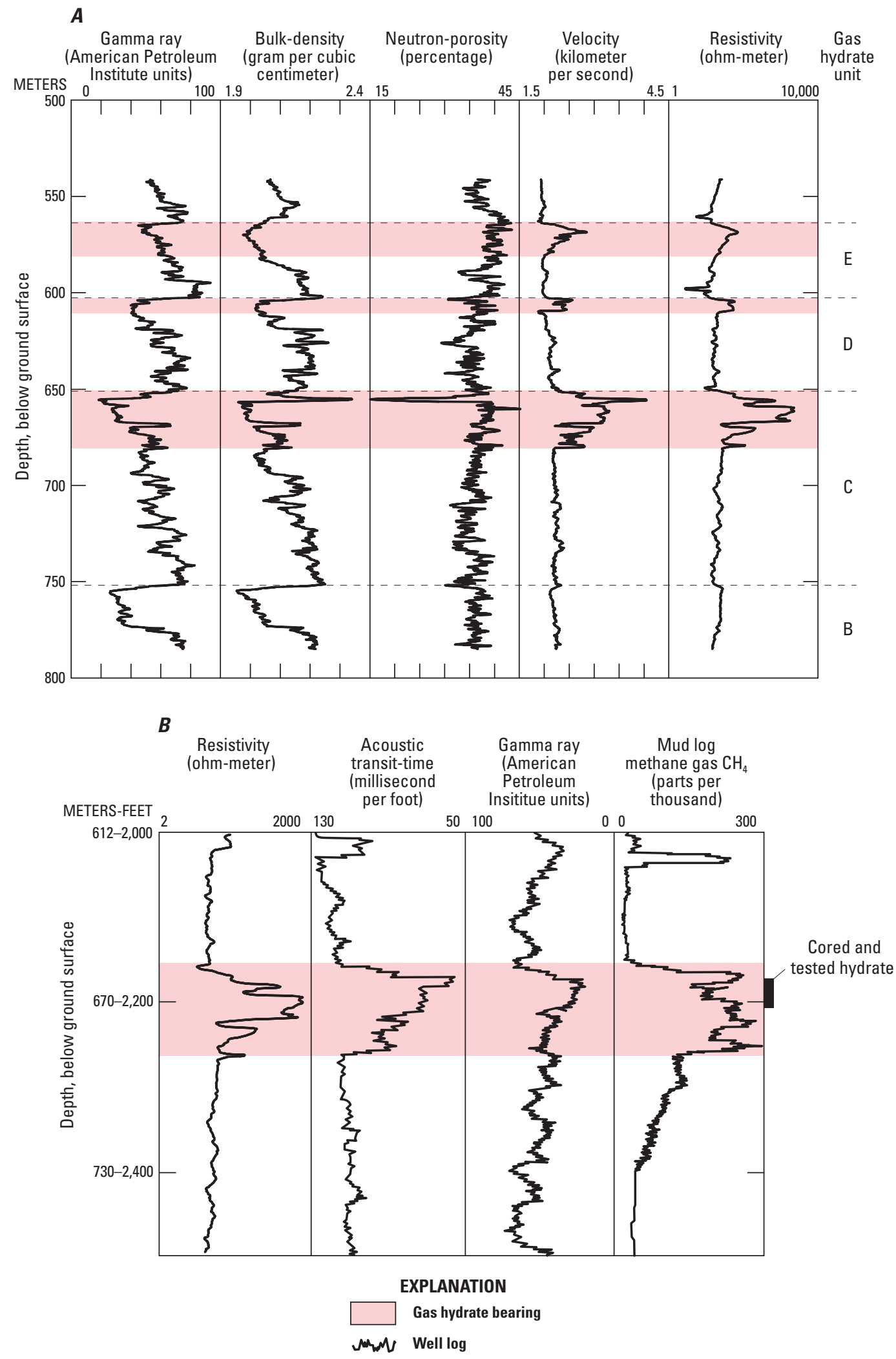

Figure 7. $A$, downhole logs from the Northwest Eileen State-2 well depicting the depth of units $\mathrm{B}, \mathrm{C}, \mathrm{D}$, and $\mathrm{E}$; data shown include the natural gamma ray log, bulk-density, neutron porosity, acoustic velocity, and electrical resistivity data. $B$, insert of well logs from the cored gas hydrate interval (unit C) in the Northwest Eileen State-2 well. Data shown include well logs and methane $\left(\mathrm{CH}_{4}\right)$ mud-log curve. See figure 9 for well location. 


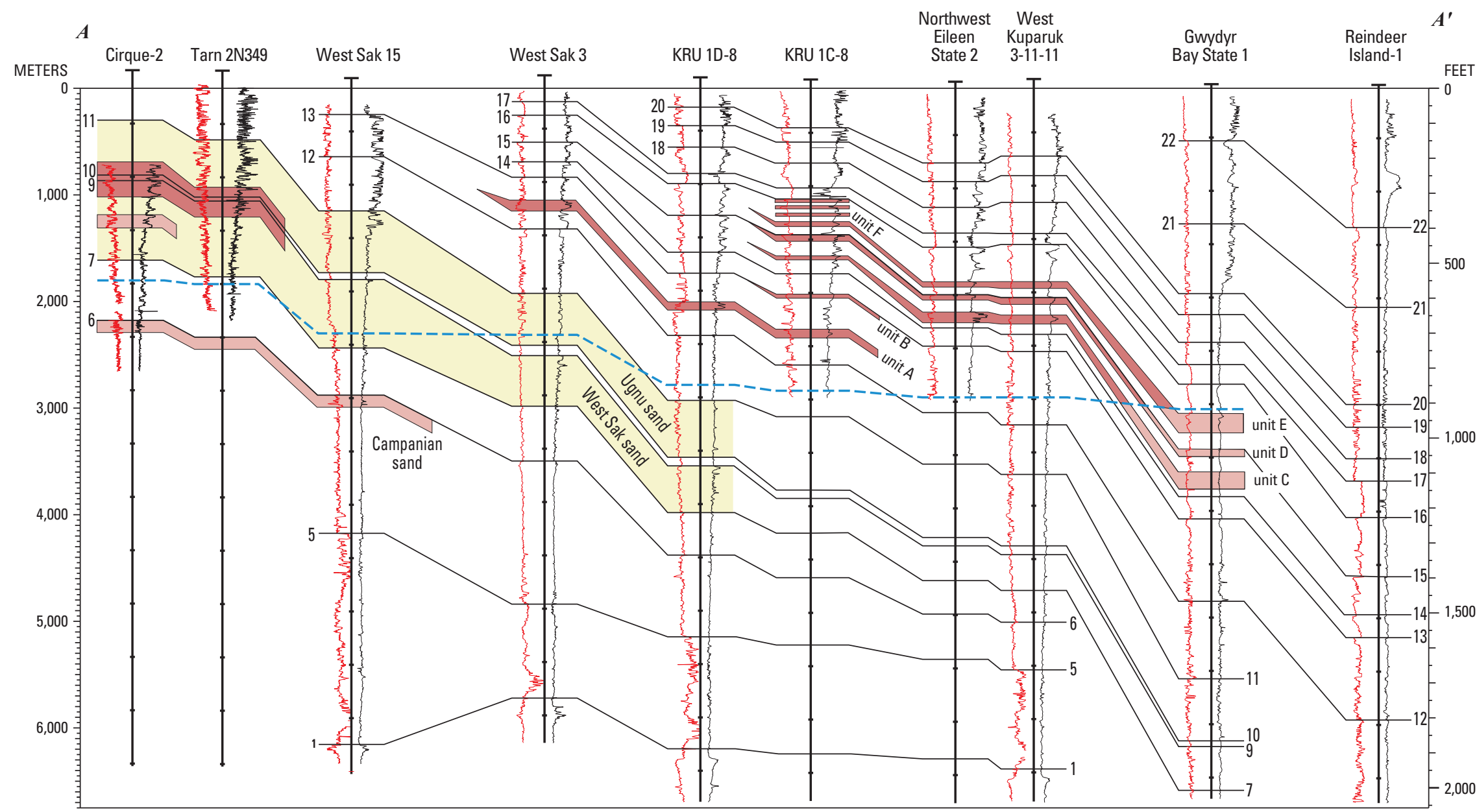

\section{EXPLANATION}

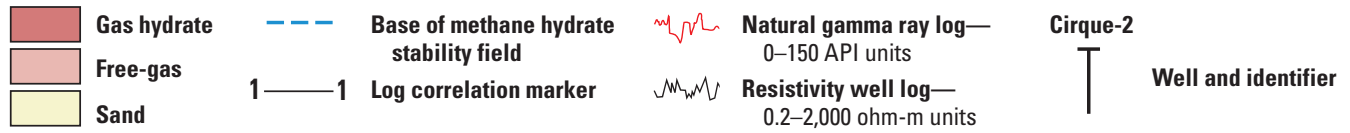

Figure 8. Well log cross section showing the lateral and vertical extent of the Eileen and Tarn gas hydrate accumulations and the associated underlying free-gas zones in the Prudhoe Bay and Kuparuk River oil fields. See figure 9 for the location of the cross section. The gas hydrate-bearing units in the Eileen accumulation are identified with the reference letters A through F. The numbered solid lines are log correlation markers used to construct a regional stratigraphic framework (modified from Collett, 1993). The gas hydrate-bearing portions of units $A$ and $B$ in the Eileen accumulation are shown as ending above the base of the gas hydrate stability zone, which is correct along the path of this southwest- to northeast-trending cross section. However, to the east and south from the Kuparuk River field into the Prudhoe Bay field, units $A$ and $B$ gas hydrates extend to the base of the gas hydrate stability zone and trap free-gas in a downdip position. 
part of the Kuparuk River field, the southern part of the Milne Point field, and the western part of the Prudhoe Bay field (figs. 8, 9). The lateral boundaries of the gas hydratebearing units as mapped by Collett (1993) are based in many places on widely-spaced well control and therefore are open to interpretation and further refinement. Also, the lateral continuity of gas hydrate occurrences between well sites is still poorly defined, but recent 3D seismic prospecting in the Milne Point area by Inks and others (2009) has provided additional insight to the lateral nature and extent of the well-loginferred gas hydrate-bearing units in the Eileen accumulation (discussed in a later section). It is also important to emphasize that seismic surveys (reviewed by Lee and others, 2009; Inks and others, 2009) and downhole logs (Collett, 1993) from wells in the western part of the Prudhoe Bay field indicate the presence of several large free-gas accumulations trapped stratigraphically downdip below five (units A-E) of the loginferred gas hydrates. The total mapped area of all six gas hydrate-units in the Eileen accumulation is about $635 \mathrm{mi}^{2}$; the areal extent of individual units ranges from 1 to $155 \mathrm{mi}^{2}$ (fig. 9). Collett (1993) estimated the total volume of gas within these accumulations at about 35.3 to $42.4 \mathrm{TCF}$.

Collett (1993) concluded that the Eileen gas hydrate accumulation is in rocks of the Mikkelsen Tongue of the Canning Formation, which were deposited during a basinwide marine transgression in the Eocene. This sequence (which is mostly marine) thins southwesterly and coarsens laterally into a sand-rich sequence in the western part of the Prudhoe Bay field. Analysis of drilling cuttings (Collett, 1993) and core from the Mount Elbert well (Rose and others, 2011) indicates that the gas hydrate-bearing reservoirs in the Eileen accumulation consist mostly of fine-grained to very fine-grained sands and coarse silts with minor amounts of interbedded coarse sands, conglomerates, and shales deposited in a range of nearshore marine and nonmarine environments. Considering the sand-rich nature of the section at the site of the Mount Elbert well, the interval containing the Eileen gas hydrate-bearing sands are now assigned to the Sagavanirktok Formation (fig. 6; Molenaar and others, 1987b; Bird, 1998: Rose and others, 2011) and are considered the age equivalent of the more distal early Eocene marine shales and minor sands of the Mikkelsen Tongue of the Canning Formation further to the east.

In February of 1992, while drilling the Cirque-1 well near the western edge of the Kuparuk River field, a shallow gas zone (depth of about 2,330 ft; $710 \mathrm{~m}$ ) was encountered that subsequently blew out the well (Alaska Oil and Gas Conservation Commission, 1992). It was later determined that the well also encountered a thick gas hydrate-bearing interval that contributed to the gas flow problem (Collett and Dallimore, 2002). Subsequent drilling of the Cirque-2 well confirmed the occurrence of gas hydrates near the base of permafrost within the depth interval of about $820 \mathrm{ft}$ to $1,150 \mathrm{ft}$ (250-350 m) (Collett and Dallimore, 2002).
Downhole log data from industry exploratory and development wells located along the western margin of the Kuparuk River field, tied to the well-log responses in the Cirque-2 well, reveal a large gas hydrate accumulation that has been named the Tarn gas hydrate accumulation (Collett, 1993; figs. 8, 9). As shown in figure 9, the Tarn gas hydrate accumulation lies in a fairway extending from the Till-1 well in the north, through the Cirque-Tarn area, to near the North Meltwater field to the south. The gas hydrate-bearing stratigraphic interval in the Tarn area appears to be the updip equivalent of the informally named West Sak sands, which are estimated to contain more than 20 billion barrels of in-place viscous oil and are the focus of development activity in a downdip position to the east of the Tarn gas hydrate accumulation (Werner, 1987). Preliminary analyses of other recently completed wells along the western margin of the Kuparuk River field indicate that the Tarn gas hydrate accumulation may be larger than the Eileen accumulation; however, the Tarn accumulation lies mostly within permafrost unlike the Eileen accumulation, which straddles the base of permafrost.

In 2003, the USGS initiated a study to develop seismic interpretive methods to identify and characterize gas hydrate accumulations and to further characterize the nature of hydratebearing reservoirs on the Alaska North Slope. This study dealt primarily with the analysis of a 3D seismic data set from the area of the Milne Point field as provided to the USGS by BP Exploration Alaska, Inc. (figs. 9, 10). Detailed analysis and interpretation of available 3D and 2D seismic data sets, along with seismic modeling and correlation with specially processed downhole well-log data, have led to the development of a viable method for identifying sub-permafrost gas hydrate prospects within the gas hydrate stability zone in the Milne Point area (Lee and others, 2009, 2011; Inks and others, 2009).

Initial seismic interpretation indicated a range of potential gas hydrate prospects, including accumulations at the base of the gas hydrate stability zone (in contact with underlying free gas) and additional hydrate prospects higher in the stratigraphic section. However, well-log data showed that the gas hydrate and free gas saturations in these deeper reservoirs were low due to leaky seals or inadequate charge (Inks and others, 2009). In 2005, the USGS project team completed their delineation, description, and ranking (including probabilistic volumetrics) of 14 gas hydrate prospects (fig. 10) within the Milne Point area. The seismic characterization of the gas hydrate prospects was based on rock physics relations calibrated with downhole log data from nearby offset wells; this enabled the prediction of gas hydrate "pay" thickness and gas hydrate saturation from analyses of seismic amplitudes and peak-trough travel-times (Lee and others, 2009).

The highest ranked Milne Point gas hydrate prospect, named Mount Elbert, is depicted in figures 10 and 11. The pre-drill site evaluation predicted that Mount Elbert would contain roughly $145 \mathrm{BCF}$ (billion cubic feet) of in-place gas 


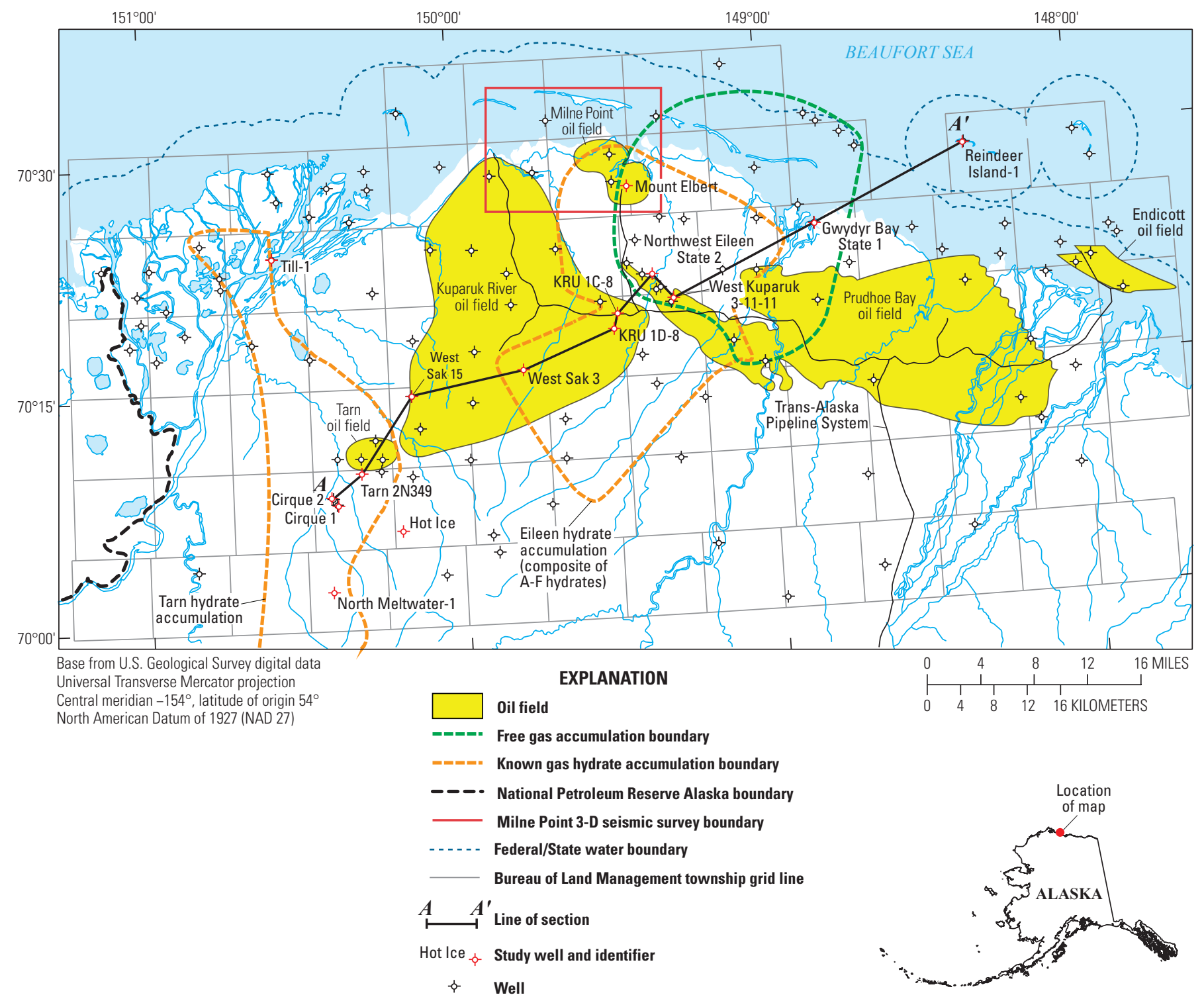

Figure 9. Map of the Eileen and Tarn gas hydrate accumulations overlying portions of the Prudhoe Bay, Kuparuk River, and Milne Point oil fields (modified from Collett, 1993). Also shown are the locations of the Northwest Eileen State-2 (NWEIL), Mount Elbert and Hot Ice gas hydrate research wells and the well log cross-section $A-B$ in figure 8, along with the outline of the Milne Point 3D seismic volume used to identify and map gas hydrate prospects.

in two reservoir sands (units C and D after Collett, 1993) (Inks and others, 2009). The Mount Elbert prospect, like all of the most promising Milne Point prospects, had not been penetrated by existing wells. Therefore, it was decided to drill a stratigraphic test well to confirm the existence of reservoirs, test the prospecting and assessment methodologies, and enable the collection of additional reservoir data to support reservoirsimulation modeling and production test design (Hunter and others, 2011). The Mount Elbert Gas Hydrate Stratigraphic Test Well was completed in February 2007 and yielded one of the most comprehensive datasets yet compiled on naturally occurring gas hydrates. The test well was designed as a 22-day program with the planned acquisition of cores, well-logs, and downhole production test data. It was first drilled and cased to a depth of 1,952 $\mathrm{ft}$ (595 m), then was continuously cored to a depth of $2,494 \mathrm{ft}(760 \mathrm{~m})$. After coring, the well was surveyed with a research-level wireline-logging program including nuclear magnetic resonance and dipole acoustic logging, resistivity scanning, borehole electrical imaging, and advanced geochemistry logging (figs. 12, 13). Following logging, Schlumberger Modular Dynamic Testing (MDT) was conducted at four open-hole stations in two hydratebearing sandstone reservoirs (fig. 13). Each test consisted of flow and shut-in periods of varying lengths, with one lasting more than 13 hours (hr). Gas was produced from the gas hydrates in each of the tests. Gas hydrates were expected and encountered in two stratigraphic zones (figs. 12, 13): (1) an upper zone (unit D) that contained roughly $46 \mathrm{ft}$ (roughly 


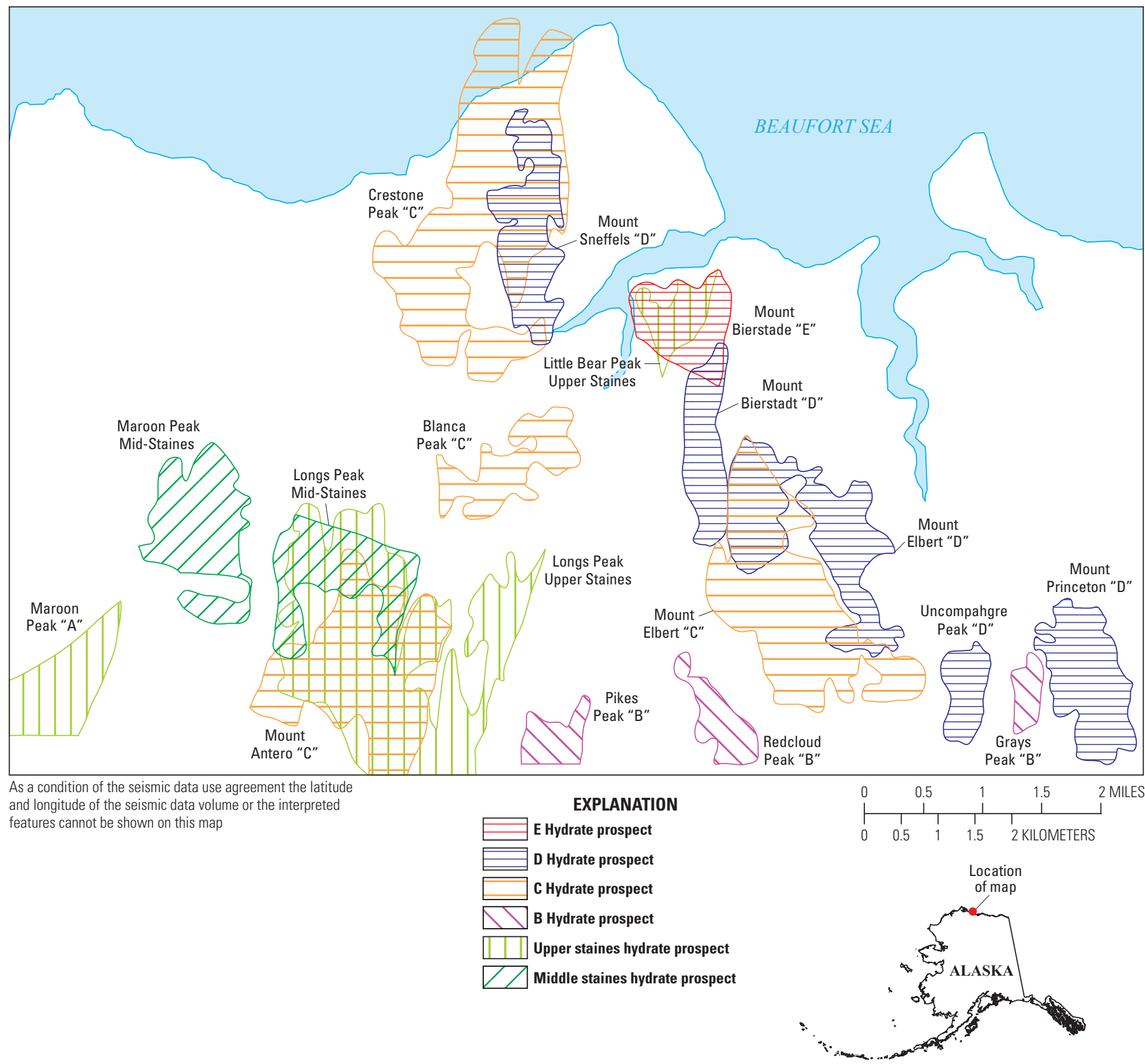

Figure 10. Milne Point area gas hydrate prospects identified with 3-D seismic interpretation. Modified from Inks and others (2009). As a condition of the seismic data use agreement, the latitude and longitude of the seismic data and the interpreted features cannot be shown on this map.

$14 \mathrm{~m}$ ) of gas hydrate-bearing reservoir-quality sandstone, and (2) a lower zone (unit C), that contained roughly $52 \mathrm{ft}$ (roughly $16 \mathrm{~m}$ ) of gas hydrate-bearing reservoir. Both zones displayed gas hydrate saturations that varied with reservoir quality as expected, with typical values between 60 percent and 75 percent. This result conclusively demonstrated the soundness of the gas hydrate prospecting methods developed primarily by the USGS (Lee and others, 2011).

The Milne Point 3D seismic gas hydrate prospecting effort also provided a greater appreciation of the lateral nature of the well-log-inferred gas hydrate-bearing sedimentary units in the Eileen accumulation. As reported by Collett (1993), the thickness of the well-log-inferred gas hydrate intervals in the Milne Point area range from roughly 10 to roughly $100 \mathrm{ft}$ (roughly 3 to roughly $30 \mathrm{~m}$ ). However, the nature of the gas hydrate occurrences between wells is poorly constrained. Collett (1993) assumed that the deposits were laterally continuous and were representative of hydrate occurrences throughout the Eileen accumulation. The Milne Point 3-D seismic analysis, however, revealed a much more "patchy" nature, as depicted in the gas hydrate prospect map in figure 10, with individual gas hydrate prospects ranging in 


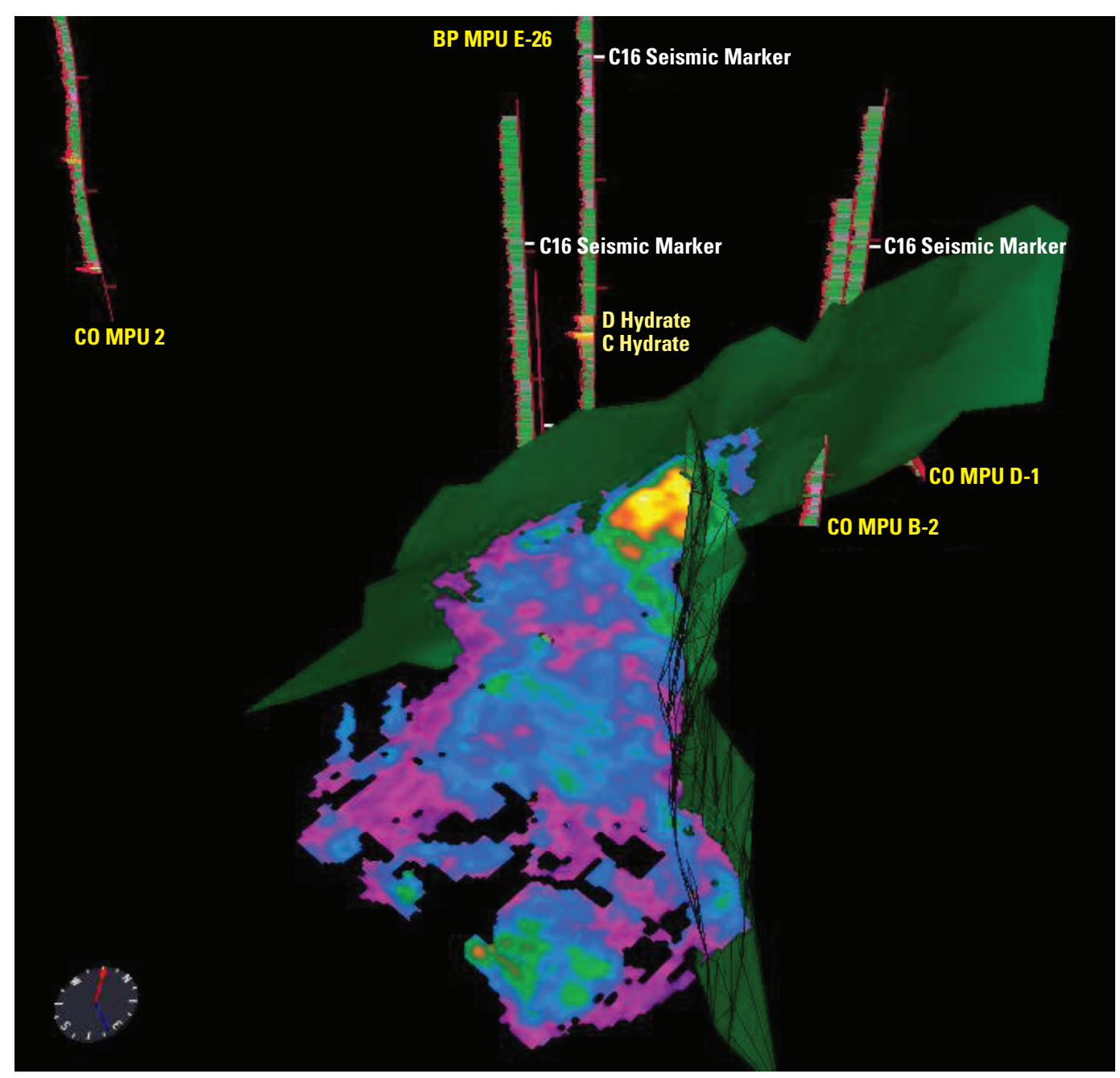

Figure 11. Milne Point Mount Elbert gas hydrate prospect. Shown are a three-dimensional image of a fault-bounded, high-amplitude feature (in a pallet of colors ranging from yellow to magenta, the yellowimaged portion contains the thickest and most concentrated gas hydrate); bounding faults (in green); and gas hydrate zones (in yellow) in nearby well penetrations as identified from geophysical log data. Modified from Inks and others (2009).

size from about 0.1 to $2.7 \mathrm{mi}^{2}$. The thickness of the seismically imaged gas hydrate occurrences in the Milne Point effort were also determined to range from roughly $30 \mathrm{ft}$ (roughly $9 \mathrm{~m}$ ) to a maximum thickness of roughly $65 \mathrm{ft}$ (roughly $20 \mathrm{~m}$ ). However, Lee and others $(2009,2011)$ demonstrated that within the Milne Point 3D seismic data volume there is no significant seismic response to gas hydrate reservoirs less than a cut-off thickness of about 25-30 ft (about 8-9 m). This indicates the probability that the relatively thinner log-inferred gas hydrate occurrences in the Milne Point area are not being seismically imaged. It is therefore likely that gas hydrates between well sites within a given stratigraphic unit are more regionally extensive than those imaged by Inks and others (2009), but thicknesses can only be inferred from available data. The local variability in the nature of the Eileen gas hydrate accumulation is likely controlled by the components of the petroleum system (that is, reservoir, gas source, and gas migration).
The Eileen and Tarn gas hydrate accumulations clearly demonstrate the role of the reservoir in a gas hydrate petroleum system. In both cases, gas hydrate is in pores of coarse-grained sedimentary rocks. It is also clear that the accumulation of gas hydrates is limited to the zone of methane hydrate stability in northern Alaska. Of most importance for this assessment, however, is that the seismicinferred hydrate accumulations on the Alaska North Slope occupy limited, discrete volumes of rock bounded by faults and downdip water contacts much like conventional hydrocarbon accumulations.

\section{4.c. Gas Source and Migration}

It has been shown that the availability of large quantities of hydrocarbon gas from both microbial and thermogenic sources is an important factor controlling the 


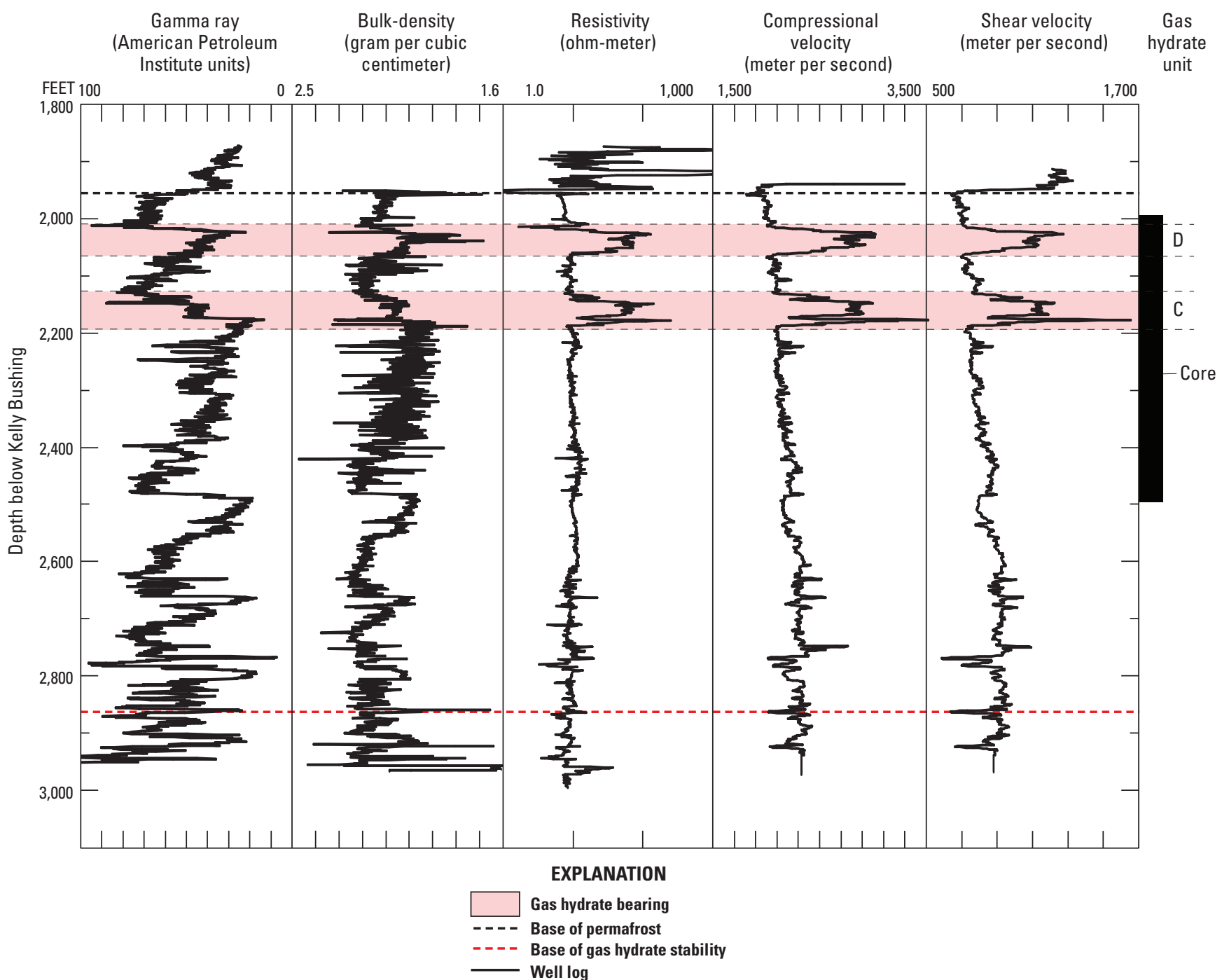

Figure 12. Open-hole well logs from the cored section of the Mount Elbert gas hydrate stratigraphic test well. Modified from Hunter and others (2011).

formation and distribution of natural gas hydrates (Collett, 1993; Kvenvolden, 1993; Collett, 2002; Lorenson and others, 2011). Carbon isotope analyses indicate that the methane in many oceanic hydrates is derived from microbial sources; however, thermal sources have been observed within several hydrate deposits in the Gulf of Mexico, the Caspian Sea, the Black Sea, and onshore in the Mackenzie Delta of Canada and in northern Alaska (reviewed by Collett, 2002). Recent studies in northern Alaska (Lorenson and others, 2011) and Canada (Dallimore and Collett, 2005) have also documented the importance of thermogenic gas sources to the formation of highly concentrated gas hydrate accumulations.

Typically, not enough microbial methane is generated internally within the gas hydrate stability zone alone to account for the gas content of most gas hydrate accumulations (Kvenvolden, 1993). In addition, most gas hydrate accumulations are in sediments that have not been deeply buried or subjected to temperatures high enough to form thermogenic gas. Thus, in most cases, the gas is likely concentrated in the hydrate stability zone by a potential combination of processes, one of which, gas migration, would appear to be the critical component within most gas hydrate petroleum systems.

In the greater Prudhoe Bay area, the Sagavanirktok Formation (fig. 6) is cut by a series of northwest-trending high-angle normal faults, generally downthrown to the east (Werner, 1987). Similar faults cut the underlying rocks in this area, suggesting a genetic linkage between the two fault systems that could provide conduits for oil and gas migration from the underlying Prudhoe Bay and Kuparuk River fields. Geochemical similarities suggest that oil and presumably the associated gas within the Sagavanirktok Formation were "spilled" from the underlying Prudhoe Bay Sadlerochit Group reservoir as a consequence of regional tilting during the middle to late Tertiary (Carman and Hardwick, 1983; Masterson and others, 2001). 


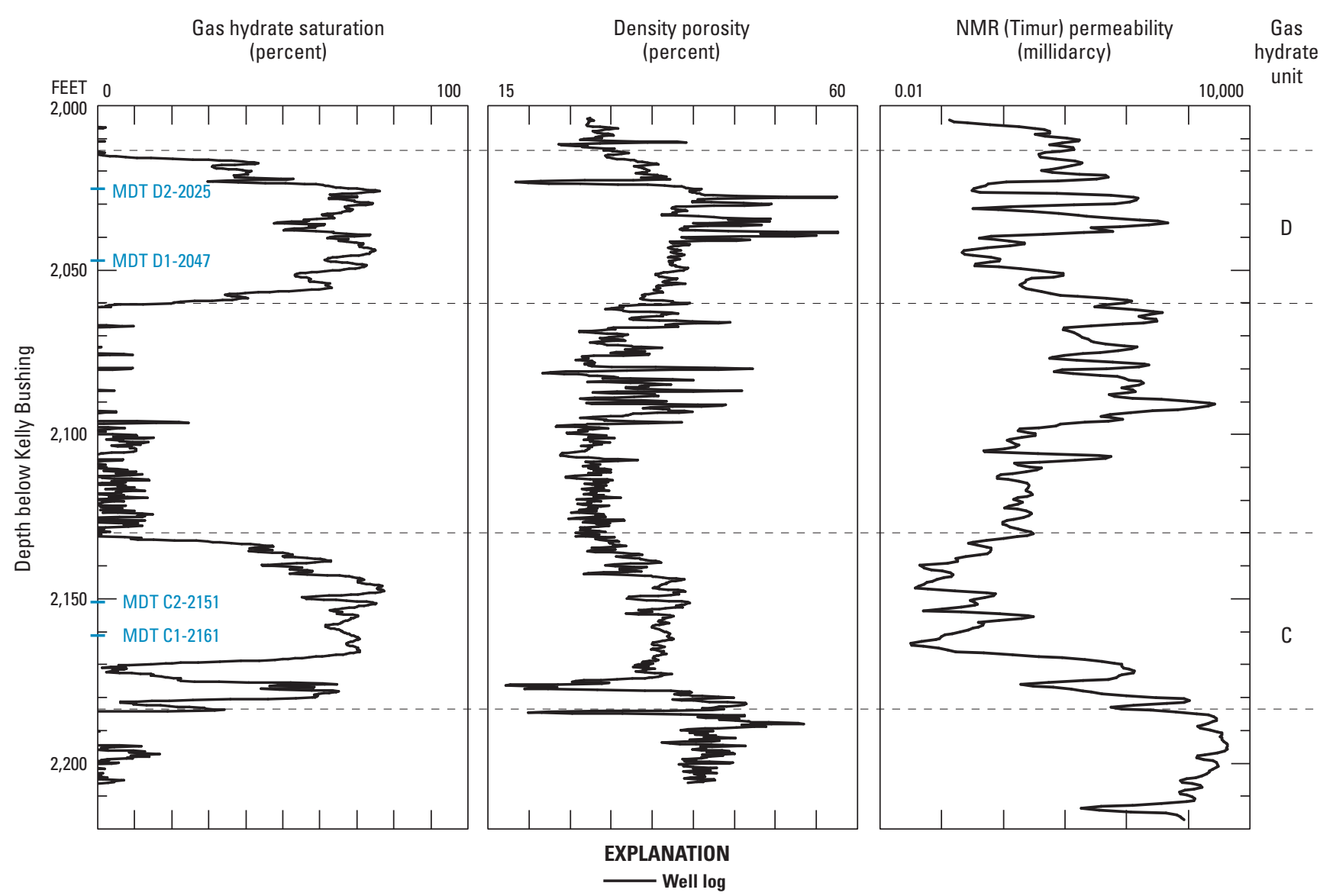

Figure 13. Well-log-derived gas hydrate saturations, density porosities, and sediment permeabilities for the two gas hydratebearing intervals (units $C$ and $D$ ) cored in the Mount Elbert gas hydrate stratigraphic test well (modified from Hunter and others, 2011). The intervals tested (Schlumberger Modular Dynamic Testing (MDT) Tests C1, C2, D1, and D2) are also shown. (NMR, nuclear magnetic resonance)

Geochemical analyses of drill cuttings and core samples from wells in both the Eileen and Tarn gas hydrate accumulations indicate that methane is the principal gas in these accumulations (Collett, 1993; Lorenson and others, 2011). Stable methane-carbon isotopic analyses show that the methane within the gas hydrate is likely from mixed microbial and thermogenic sources, with the apparent thermogenic methane migrating from deeper sources, including the Prudhoe Bay field. Masterson and others (2001) and Lorenson and others (2011) have shown that evaporative fractionation and biodegradation of the Sadlerochit-sourced oil in the Sagavanirktok Formation is also an important source of gas within the gas hydrates of both the Eileen and Tarn gas hydrate accumulations.

Collett (1993) adapted a generalized cross section (fig. 14) from Carman and Hardwick (1983) to describe the history of the Eileen and Tarn gas hydrate accumulations. Collett postulated that as thermogenic gas and associated oil moved up the Eileen and other fault zones and encountered the relatively porous and permeable northeast-dipping Sagavanirktok sandstone reservoir units, some of the gas may have been rechanneled updip along these beds. The updip-migrating gas

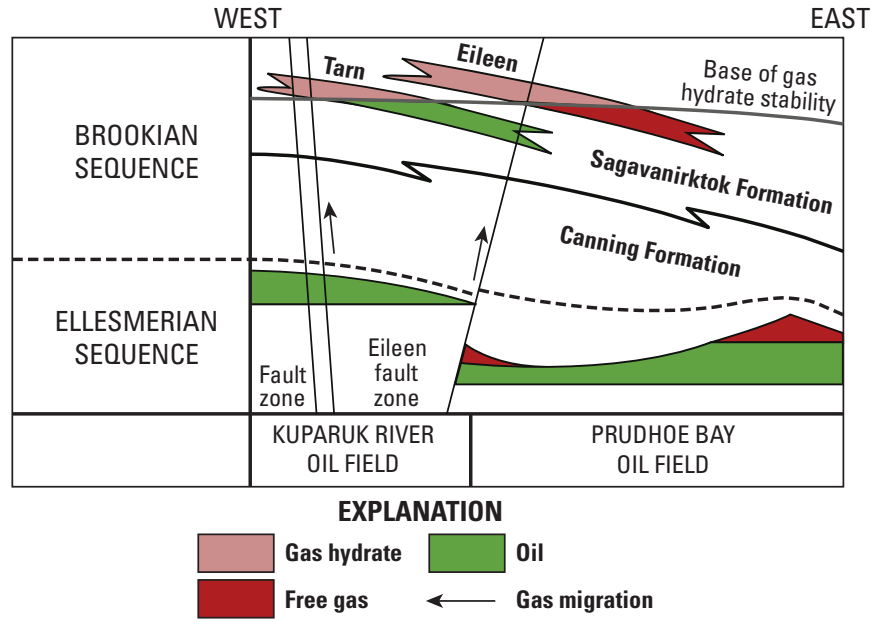

Figure 14. Schematic west to east cross section through the Prudhoe Bay and Kuparuk River fields illustrating possible gasmigration paths and spatial relations between the Eileen and Tarn gas hydrate accumulations, free-gas and oil accumulations, Eileen and other fault zones, and base of gas hydrate stability (modified from Carman and Hardwick, 1983). 
may have mixed with in-situ microbial methane and collected in structural and stratigraphic traps where falling temperatures at the end of the Pliocene deepened the permafrost section and converted the trapped gas into gas hydrate.

As discussed above, gas hydrate in onshore Arctic environments is typically closely associated with permafrost. It is generally believed that thermal conditions conducive to the formation of permafrost and gas hydrate persisted in the Arctic since the end of the Pliocene (about 2.59 million years ago) (Collett, 1993, 2002; Lee and others, 2008). From Milne Point seismic and other studies, it also appears that most permafrost-associated gas hydrate accumulations probably developed from preexisting free-gas fields that originally formed in conventional hydrocarbon traps and were later converted to gas hydrate upon the onset of glaciation and cold Arctic conditions (Collett, 1993, 2002; Lee and others, 2009, 2011; Inks and others, 2009; Boswell and others, 2011).

\section{Gas Hydrate Production Analysis}

Although gas hydrates are known to occur in numerous marine and Arctic settings, until recently little was known about the technology necessary to produce gas from them. Proposed methods of gas recovery from hydrates (reviewed by Collett, 2002) generally deal with dissociating or "melting" in-situ gas hydrates by: (1) heating the reservoir beyond hydrate-forming temperatures, (2) injecting an inhibitor such as methanol or glycol into the reservoir to decrease hydrate stability, and (or) (3) decreasing the reservoir pressure below hydrate equilibrium. Recently, several studies have shown that it may be possible to produce methane from hydrates by displacing the methane molecule in the hydrate structure with carbon dioxide; thus releasing methane and sequestering the carbon dioxide (Graue and others, 2006). Among the possible techniques for production of natural gas from in-situ gas hydrates, depressurization is considered to be the most economically promising (reviewed by Collett, 2002) and is the only method of gas hydrate production considered in this assessment.

The USGS conventional assessment approach also assumes that the hydrocarbon resource being assessed can be produced by existing conventional technology. The production potential of the known and seismically-inferred gas hydrate accumulations in northern Alaska has not been adequately field tested, but has been the focus of a U.S. Department of Energy (DOE) gas hydrate production research modeling effort as reviewed by Anderson and others (2008). Although verified by only limited field testing (Dallimore and others, 2008a, 2008b; Yamamoto and Dallimore, 2008), numerical production models (for example Anderson and others, 2008) of gas hydrate-bearing reservoirs suggest that gas can be produced from gas hydrate with existing conventional technology. This conclusion is supported by a growing body of evidence indicating that concentrated gas hydrate accumulations in conventional hydrocarbon reservoirs, such as those in northern Alaska, can be produced with existing technology.

Field studies and associated production modeling studies, such as the Mallik 2002 (Dallimore and Collett, 2005), the Mallik 2006-2008 (Dallimore and others, 2008a, 2008b; Yamamoto and Dallimore, 2008), and the Mount Elbert projects (Hunter and others, 2011) have contributed greatly to our understanding of the technologies required to produce gas hydrates. The results of the gas hydrate-testing programs in northern Canada and Alaska are discussed below, together with a review of the rapidly evolving field of gas hydrateproduction simulation.

\section{5.a. Gas Hydrate Production Testing Results}

The Messoyakha field, a gas field located in the northern part of the West Siberian Basin, is commonly used as an example of a hydrocarbon accumulation from which gas has been produced from hydrates by reservoir depressurization (Makogon, 1981). Production data and other geologic information have been used to document the presence of gas hydrates within the upper part of the Messoyakha field (reviewed by Collett and Ginsburg, 1998). Long-term production from the gas hydrate part of the Messoyakha field is presumed to have been achieved by simple depressurization. As production began from the lower free-gas portion of the Messoyakha field in 1969, the measured reservoir pressures followed predicted decline relations; however, by 1971, the reservoir pressures began to deviate from expected values. This deviation has been attributed to the liberation of gas from dissociating gas hydrates. Throughout the production history of the Messoyakha field, it is estimated that about 36 percent (about $177 \mathrm{BCF}$ ) of the gas withdrawn from the field was from gas hydrate (Makogon and others, 1972). Glenn and Allen (1991) presented evidence that a similar phenomenon may be occurring within gas fields in the vicinity of the city of Barrow in northern Alaska. It should be noted that several later studies do not support the interpretation that gas hydrate contributes significantly to gas production in the Messoyakha field (reviewed by Collett and Ginsburg, 1998).

One of the major goals of the Mallik 2002 Gas Hydrate Production Research Well Program (Dallimore and Collett, 2005) was to advance research pertaining to gas hydrate production by undertaking a suite of well-constrained, short-term production experiments. The scientific goals of this production testing effort were to confirm the feasibility of natural gas production by depressurization and by thermal-stimulation techniques. With these goals in mind, the tests produced gas from gas hydrate with a series of well-constrained and controlled production experiments, each designed to investigate the response of in-situ gas hydrate deposits to changes in pressure or temperature. 
The Mallik 2002 production test results, combined with other project data, were also used to calibrate gas hydrateproduction simulators, which were then used to predict the expected long-term response of the gas hydrate beyond the duration and conditions of the actual tests.

During the Mallik 2002 testing program, the response of gas hydrates to heating and depressurization was evaluated with careful attention to accurately measuring both input conditions and reservoir responses. Pressure draw-down experiments, designed to study the response of gas hydrate to a reduction in formation-pressure conditions, used Schlumberger's Modular Formation Dynamics Tester (MDT) wireline tool to conduct small-scale pressure-drawdown tests within five perforated intervals in the Mallik 5L-38 well. The rationale for most of the MDT tests was to reduce reservoir pressure below gas hydrate stability conditions and then "shut-in" the tool to observe the pressure build-up attributed to flowing formation fluids and gas hydrate dissociation.

The results of three short duration tests demonstrate that gas can be produced from gas hydrates with different concentrations and characteristics, exclusively through pressure stimulation. It was shown (Hancock and others, 2005) that the response of the hydrate-bearing sand reservoirs was similar to a conventional porous-media response. Thus, conventional pressure-transient analytical techniques were used to evaluate the Mallik 2002 MDT test data. Horizontal permeabilities were observed to range from less than 0.001 millidarcy $(\mathrm{mD})$ to as much as $0.1 \mathrm{mD}$ within hydratebearing porous media. In contrast, the expected intrinsic permeability (that is, without gas hydrate) of the same sands with only water filling the pores would be on the order of 100 to $1,000 \mathrm{mD}$. The existence of measurable permeability in a reservoir with high gas hydrate saturations (up to 85 percent) was unexpected. Downhole-measured NMR-log data from the Mallik 5L-38 well also indicated the presence of a movable free-water phase within the hydrate-bearing sandstone reservoirs, which likely represents the compressive porous-media fluid phase along which flow was established and measured during the MDT gas hydrate tests. Downhole acoustic log data from Mallik also shows that gas hydrate is a matrix-supporting, pore-filling material rather than a graincoating substance. The presence of an interconnected fluid phase at measurable permeabilities indicates that gas hydrate reservoir-depressurization production techniques may be more effective than previously thought.

Thermal stimulation experiments were designed to destabilize gas hydrates by using circulated hot water to increase the in-situ temperature. A five-day experiment was undertaken within a 13-m-thick section of highly concentrated gas hydratebearing strata. The test was conducted by circulating hot fluids $\left(122^{\circ} \mathrm{F} ; 50^{\circ} \mathrm{C}\right)$ down the hole at a constant pressure slightly above hydrostatic conditions. Gas from dissociated hydrate flowed to the surface, and was separated from the circulating fluid, measured, sampled, and flared. Gas was continuously produced throughout the test at varying rates with maximum flow rate reaching 12,700 standard cubic feet of gas per day (scf/day) (Dallimore and Collett, 2005). The total volume of gas was small, reflecting that the test was a controlled production experiment rather than a long-duration conventional well test. It also demonstrated the difficulty of heating a relatively large rock mass by conductive heat flow alone.

The Mallik 2002 production research well program proved for the first time that gas production from gas hydrates is technically feasible. The resulting data allowed (1) the calibration of several reservoir models used to simulate the thermal and depressurization tests, and (2) the rational assessment of the production response of a gas hydrate accumulation if the various tests were extended far into the future. These studies also show that among the possible techniques for production of natural gas from in-situ gas hydrates, depressurization would produce more gas than just heating the formation. However, the combination of heating and depressurizing the gas hydrate at the same time would produce the greatest amount of gas.

It is recognized that the Mallik 2002 project contributed a great deal to an understanding of gas hydrates; however, it fell short of delivering all of the data needed to fully calibrate existing reservoir simulators. It was also determined that longer-duration production tests would be required to assess the technical viability of long-term production from gas hydrates; the 2006-2008 Japan Oil, Gas and Metals National Corporation/Natural Resources Canada (JOGMEC/NRCan) Mallik Gas Hydrate Production Research Program was conducted to address these needs.

As described by Dallimore and others, (2008a, 2008b) and Yamamoto and Dallimore (2008), the 2006-2008 JOGMEC/NRCan Mallik Gas Hydrate Production Research Program was conducted by JOGMEC, NRCan, and the Aurora College/Aurora Research Institute to build on the results of the Mallik 2002 project, with the main goal of monitoring long-term production behavior of gas hydrates. The primary objective of the winter 2006-2007 field activities was to install equipment and instruments to allow for long-term gas hydrate production testing during the winter of 2007-2008. The Mallik 2L-38 and Mallik 3L-38 wells were reentered and each well was logged to establish formation properties prior to testing. After completing drilling operations during the 2006-2007 phase of the project, a short pressure drawdown test was conducted to evaluate equipment performance and assess the short term "producibility" of the gas hydratebearing reservoir. A 40-ft-thick gas hydrate interval $(3,586-3,626 \mathrm{ft} ; 1,093-1,105 \mathrm{~m})$ near the base of the gas hydrate stability zone was tested for $60 \mathrm{hr}$ by reducing the bottom-hole pressure down to roughly 1,060 psi (equal to a drawdown pressure of roughly $535 \mathrm{psi}$ ). Irregular pumping operations, related to excessive sand production, resulted in unstable fluid flow, which greatly complicated the analysis of the test. However, during the most successful $12.5 \mathrm{hr}$ of the 
test, at least roughly $29,300 \mathrm{scf}$ of gas were produced. The test results verified the effectiveness of the depressurization method even for such a short duration.

The following winter (2007/2008), the team returned to the site to undertake a longer term production test with the implementation of countermeasures to overcome the problems encountered in the previous year's program. The 2007/2008 field operations consisted of a six-day pressure drawdown test, during which "stable" gas flow was measured at the surface. The 2007/2008 testing program at Mallik established a continuous gas flow ranging from roughly 70,000 to roughly $140,000 \mathrm{scf} /$ day, which was maintained throughout the course of the six-day (139-hr) test (Yamamoto and Dallimore, 2008; Dallimore and others, 2008b). Cumulative gas production volume was approximately roughly $460,000 \mathrm{scf}$. Total water production during the test was less than roughly 850 barrels (Dallimore and others, 2008b). The 2006-2008 Mallik production tests have shown that "sustained" gas production from hydrates can be achieved by depressurization alone.

As concluded by Yamamoto and Dallimore (2008), all of the Mallik gas hydrate research programs have contributed greatly to an understanding of the energy resource potential of gas hydrates. However, more work is needed to understand the longer-term production response of gas hydrates, and additional production data sets are required to develop a practical understanding of the energy-resource potential of gas hydrates.

As previously discussed in this report, the Alaska Mount Elbert gas hydrate stratigraphic test well project included the acquisition of pressure transient data from four short-duration open-hole dual-packer pressure-drawdown tests using Schlumberger's wireline MDT (Anderson and others, 2008). These tests were conducted in open-hole and were designed to build upon the knowledge gained from cased-hole MDT tests conducted during the Mallik 2002 testing program.

Four 1-m thick zones were tested in the Mount Elbert well (fig. 13): two in unit $\mathrm{C}$ (tests $\mathrm{C} 1$ and $\mathrm{C} 2$ ) and two in unit D (tests D1 and D2). Each test consisted of multiple stages of varying duration, with each stage consisting of a period of fluid withdrawal (thereby reducing formation pressure) followed by a period where the pump was shutoff and the subsequent pressure build-up was monitored. Gas and water samples were collected during selected flow periods, and a fluid analyzer on the MDT tool enabled the identification (but not volumetric measurement) of gas and water as it entered the tool.

The Mount Elbert MDT program included two types of tests. To investigate the petrophysical properties of the hydrate-bearing reservoirs, each MDT tests began with a "pre-flow test," in which pressure was reduced enough to mobilize unbound formation water but not enough to induce gas hydrate dissociation. To provide insight into gas hydrate response to small scale pressure transients, the pre-flow tests were followed by numerous test stages in which the pressure reduction was great enough to induce gas hydrate dissociation. Much like the MDT results and the downhole-measured NMR logs from the Mallik 5L-38 well (as discussed above), the MDT and NMR log data from the Mount Elbert well also confirmed the presence of a mobile pore-water phase even in the most highly gas hydrate-saturated intervals. In the Mount Elbert unit D sand, the mobile water phase was determined to be about 8 to 10 percent of total pore volume. In the unit $\mathrm{C}$ sand, it appears to range upward to roughly 15 percent (Anderson and others, 2008).

The presence of a mobile water phase appears to be a required prerequisite for the initiation of depressurization for a gas hydrate reservoir that is not in contact with underlying free-gas or water reservoirs. The MDT test data from the early pre-flow stage that targeted fluid withdrawal without gas hydrate dissociation produced pressure responses that are typical of low-permeability porous media, much like the Mallik 2002 MDT tests. Analysis of these pre-flow tests in a variety of advanced reservoir simulators (Anderson and others, 2008) has yielded reservoir permeabilities, in the presence of a gas hydrate phase, of 0.12 to $0.17 \mathrm{mD}$. Gas hydrate dissociation and production was confirmed in the later stages of each test in which the pressure was drawn down below gas hydrate equilibrium conditions.

In the next section of the report, we review how the Mallik and Mount Elbert production test results are being used to calibrate existing gas hydrate-production simulators and how these models were used in this assessment to predict expected gas production rates from various gas hydrate accumulations in northern Alaska.

\section{5.b. Gas Hydrate Production Modeling}

Over the past 10 years, there have been significant advancements in gas hydrate production computer simulators, with studies by Moridis and others (2009, 2011a, 2011b) showing promise for simulating gas production from hydrates in northern Alaska. To better understand the potential reservoir response for the locations considered in this assessment, the USGS collaborated with the participants of the International Code Comparison Group (Anderson and others, 2011a, 2011b) to conduct numerical gas hydrate-production simulations for the idealized Milne Point Unit (MPU), Kuparuk River Unit (KRU), Prudhoe Bay Unit (PBU), and Down-DipPBU settings (fig. 15). For ease in making comparisons, the geologic representations input to the models were simplified and homogenized. These analyses relied heavily on the reservoir data acquired from Mount Elbert test well in order to compare production between different geologic settings and between the various participating modeling approaches. Given the similarity of the KRU and MPU settings, only three sets of modeling runs were undertaken (figs. 16A-C). 

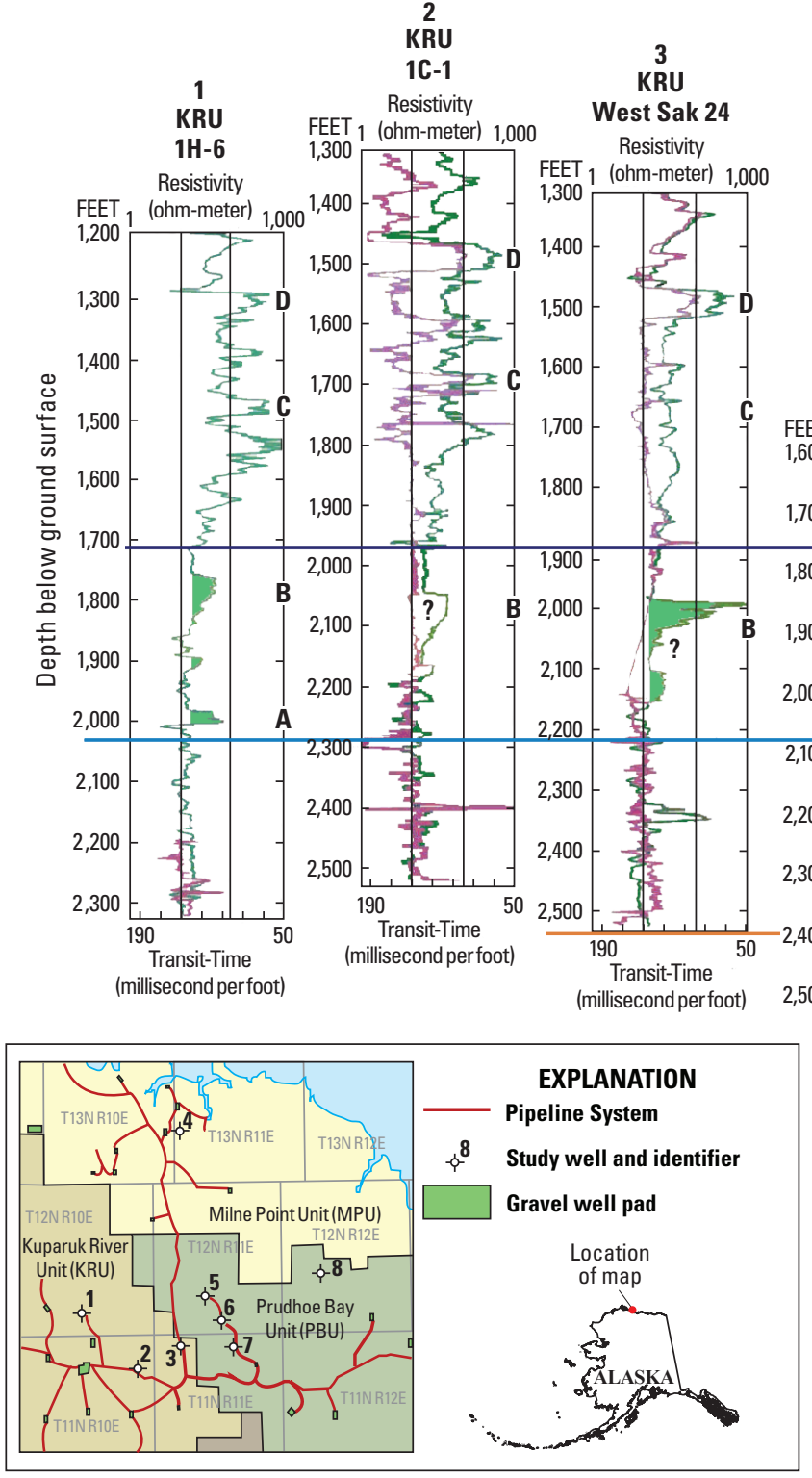

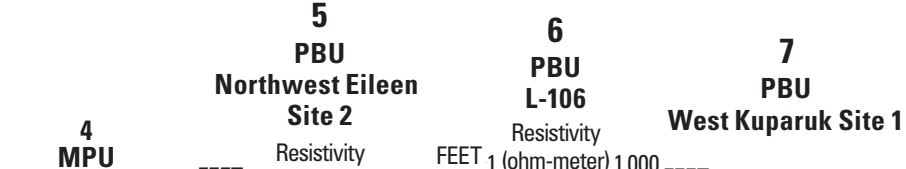

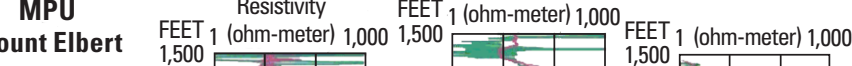

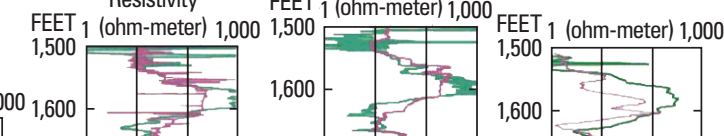

FEET 1 (ohm-meter) 1,000 1,600
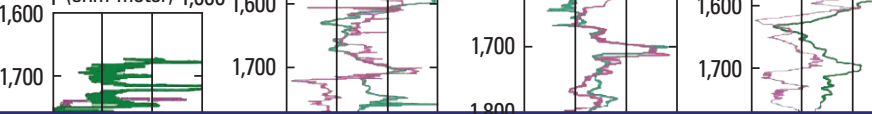

हो

Base of permafrost

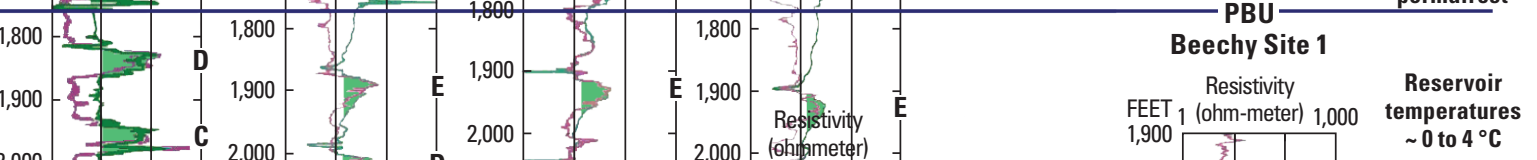

2,000

$\Rightarrow \quad C_{D}^{2}, 000-\frac{1}{-1}$

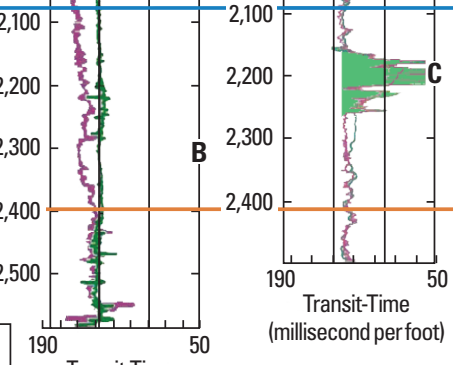
Transit-Time (millisecond perfoot) (millisecond perfoot)

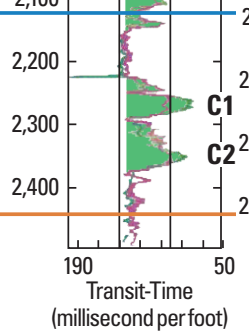

2,000 - (ohismeter) 1,900 (ohm-meter) 1,000 temperatures
(t) $2,100 \frac{1}{D} \quad$ D 2,000

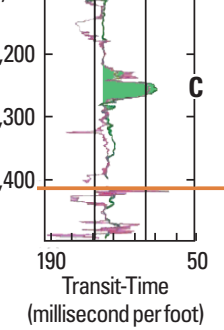

Approximate base of gas hydrate stability

$2,200-100-\begin{gathered}\text { Reservoir } \\ \text { temperatures }\end{gathered}$
ot)

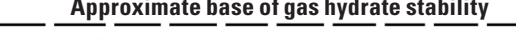

EXPLANATION

\begin{tabular}{|c|c|c|c|}
\hline \multicolumn{4}{|c|}{ EXPLAINAIIUIN } \\
\hline & Gas hydrate & $\mathrm{E}$ & $\begin{array}{l}\text { Informal unit designation- } \\
\text { After Collett } 1993\end{array}$ \\
\hline & Potential free gas & $?$ & Unreliable log data \\
\hline mans & Resistivity log & & \\
\hline mans & Acoustic travel tim & & \\
\hline
\end{tabular}

Figure 15. Montage of log data from wells drilled in Prudhoe Bay Unit (PBU), Kuparuk River Unit (KRU), and Milne Point Unit (MPU) areas. The data are shown relative to interpreted base of ice-bearing permafrost. The indicated zones of reservoir temperature are approximate. Note that the PBU logs $(5,6,7)$ show inferred gas hydrate in multiple zones and are the deepest (warmest) identified locations of gas hydrate in areas with established surface facilities. The next data point downdip from these wells (Well \#8) has relatively poor log data and the anomalous responses that may reflect drilling effects. 

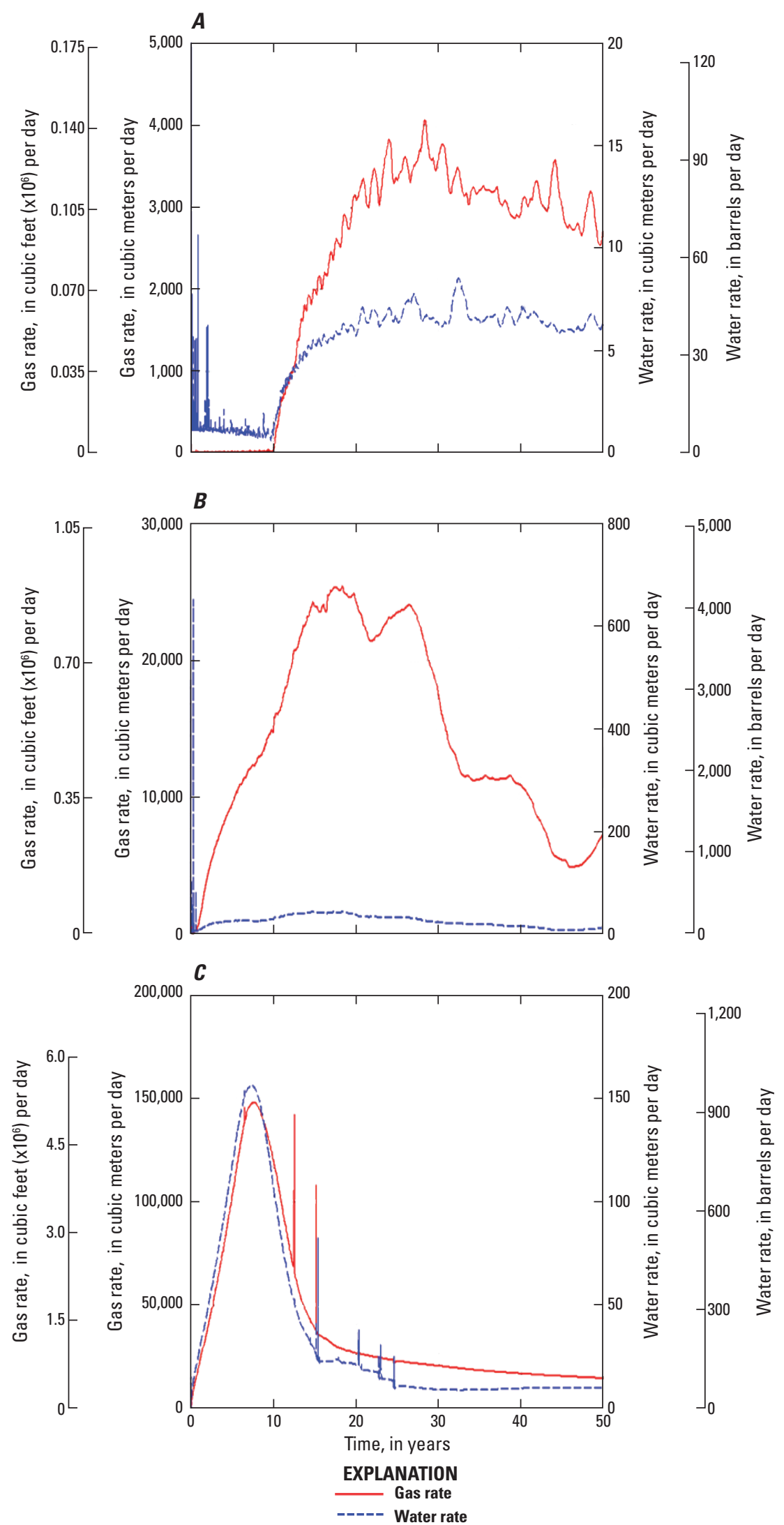

Figure 16. Comparison of typical production simulation results for Alaska North Slope gas hydrate reservoirs. $A$, setting typical for known Kuparuk River Unit (KRU) and Milne Point Unit (MPU) reservoirs $\left(3-4^{\circ} \mathrm{C}\right)$; $B$, Westend Prudhoe Bay Unit (PBU) setting $\left(5-6^{\circ} \mathrm{C}\right) ; C_{1}$ downdip PBU setting $\left(10-12^{\circ} \mathrm{C}\right)$. From Anderson and others (2011b). 
Although these cases differed somewhat in reservoir thickness and pressure, sensitivity runs clearly demonstrated that initial reservoir temperature is the primary control on the modeled production rates, with reservoir petrophysics, including intrinsic reservoir permeability, in-situ "relative" permeability, and mobile water saturation also being important (Anderson and others, 2011b). The initial MPU modeling results (fig. 16A) showed consistent predictions between the various participating codes, with modest production rates (maximum predicted production rate of 350,000 scf/day) and long "lead" times (time before first gas production occurs and all production is water). Analysis of the PBU case (production from the composite unit $\mathrm{C}$ sands) resulted in production rates (maximum predicted production rate of $825,000 \mathrm{scf} /$ day) roughly three times those of MPU and with no lead time (fig. 16B). The Down-Dip-PBU case revealed the clear benefits of higher temperatures, with rates (maximum predicted production rate of 4,300,000 scf/day) increasing another five-fold (fig. 16C; Anderson and others, 2011b). Subsequent incorporation of more detailed geologic input data sets for these locations (that is, detailed vertical reservoir heterogeneity) resulted in increased production rates and the elimination of the production lead time as seen in the MPU model (Anderson and others, 2011b).

As discussed above, the earlier reservoir models (KRU, PBU, and the Down-Dip-PBU models, figs. $16 A-C$ ) were based on homogeneous reservoir descriptions, neglecting actual complex reservoir conditions. As shown by Anderson and others (2011b), significant differences between homogeneous and heterogeneous reservoir descriptions can yield much different model results. Therefore, to better constrain the possible extent of disturbance caused by long-term depressurization of a gas hydrate reservoir and to more accurately model the possible gas- and water- production rates, a heterogeneous reservoir model was constructed. Figure 17 shows the hydrate saturations for the upper and lower $\mathrm{C}$ sand units as determined by the Archie (1942) relation in the PBU L-106 well. Similar to the homogeneous PBU L-Pad area simulations (as discussed above), the radial extent of the reservoir modeled is roughly $1,475 \mathrm{ft}(450 \mathrm{~m})$ and the two hydrate layers are each roughly $59 \mathrm{ft}(18 \mathrm{~m})$ thick, with roughly $30 \mathrm{ft}(9 \mathrm{~m})$ of shale between. The top and bottom confining layers are each $328 \mathrm{ft}(100 \mathrm{~m})$ thick and the porosity of the hydrate-bearing zones is taken from the porosity $\log$ in the PBU L-106 well. The upper and lower boundary temperatures were kept constant at $34.9^{\circ} \mathrm{F}$ $\left(1.6^{\circ} \mathrm{C}\right)$ and $39.4^{\circ} \mathrm{F}\left(4.1^{\circ} \mathrm{C}\right)$, respectively.

Depressurization simulations were performed assuming a constant bottom-hole pressure of $392 \mathrm{psi}(2.7 \mathrm{MPa})$, just above the quadruple point for the methane hydrate system in order to prevent the formation of ice in the reservoir. Figure 18 shows the predicted gas and water rates from the heterogeneous simulations on the PBU L-Pad area hydrate deposit. As shown in figure 18 , the water rate is predicted to start at its maximum and decrease throughout production, whereas the modeled gas rate increases rapidly throughout the early stages of production. As shown in Anderson and others (2011b), homogeneous L-Pad area hydrate reservoir models predict maximum gas-production rates as high as $1,000,000 \mathrm{scf} /$ day after a couple of decades of production. However, as shown in figure 18, a heterogeneous reservoir simulation results in predicted gas rates on the order of 3,500,000 scf/day with produced water rates ranging from 1,000-3,000 barrels/day throughout the first six months of depressurization.

With predicted gas production rates from known gas hydrate accumulations in northern Alaska as high as 3,500,000 scf/day, based on existing production technology, there do not appear to be any technical barriers to resource extraction from hydrates; the remaining resource issues deal mostly with the economics of hydrate extraction.

\section{Gas Hydrate Assessment Methodology}

As introduced in the "USGS Oil and Gas Assessment Methodology" section of this report, an assessment begins (fig. 2) with the volume of rock to be assessed in the total petroleum system (TPS) being apportioned into homogeneous subunits termed assessment units (AUs). The assessment procedure generally estimates the number and size of undiscovered hydrocarbon accumulations and assesses the geologic risk associated with each AU. The next section of the report focuses on defining the limits and nature of the Northern Alaska Gas Hydrate TPS and three associated AUs, the geologic risk associated with each $\mathrm{AU}$, and the methods used to estimate the size and number of undiscovered gas hydrate accumulations in each AU.

\section{6.a. Northern Alaska Gas Hydrate Total Petroleum System and Assessment Units}

The Northern Alaska Gas Hydrate TPS (figs. 19A-B) includes Cretaceous and Tertiary reservoir rocks divided into three AUs: from oldest to youngest, the Nanushuk Formation Gas Hydrate AU (fig. 20), the Tuluvak-Schrader BluffPrince Creek Formations Gas Hydrate AU (fig. 21), and the Sagavanirktok Formation Gas Hydrate AU (fig. 22).

The geologic model used to define the AUs and to set the limits of the TPS involved defining and characterizing the components of the gas hydrate petroleum system (this is, gas hydrate stability conditions, gas hydrate reservoirs, and gas source and migration) that controlled the presence of gas hydrate accumulations in each AU. As a first step, the factors controlling gas hydrate phase equilibria (which are mostly a function of formation temperature and pressure as described in the "Gas Hydrate Stability Conditions" section of this report) were assessed to map the spatial distribution of the gas hydrate stability zone in northern Alaska (fig. $5 A-C$ ). The gas hydrate stability maps in figures $5 A$ and $5 B$ depict the top and base of the gas hydrate stability zone; gas hydrates cannot be present either above or below the zone of gas hydrate stability. Figure $5 C$ shows the thickness and spatial limits of the 


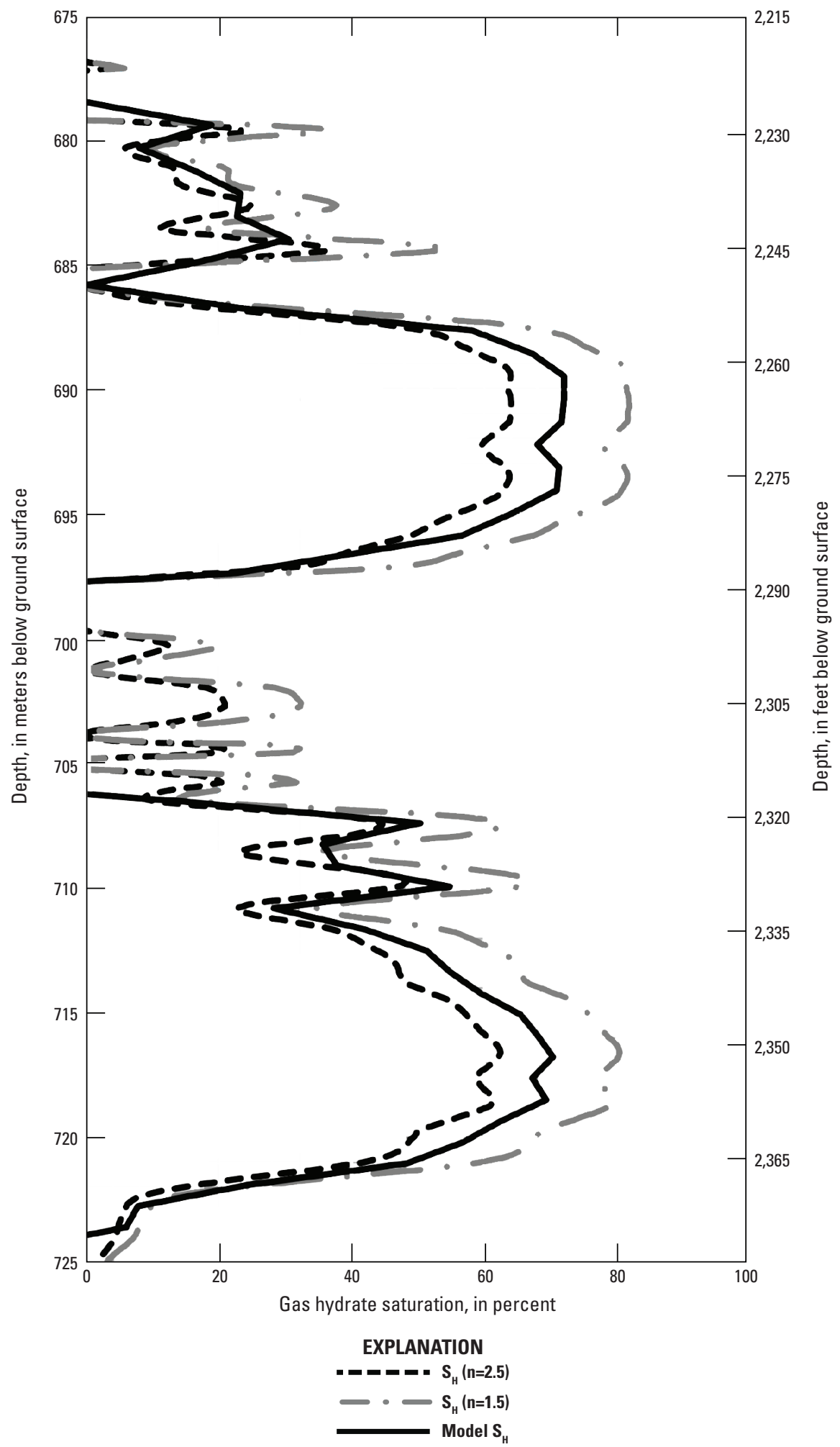

Figure 17. Hydrate saturation in the Prudhoe Bay Unit (PBU) L-106 well as calculated

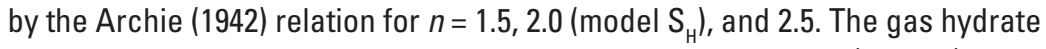
saturation in the reservoir model for the layers between $697.7 \mathrm{~m}(2,289 \mathrm{ft})$ and $706.2 \mathrm{~m}$ $(2,317 \mathrm{ft})$ was assumed to be zero. 


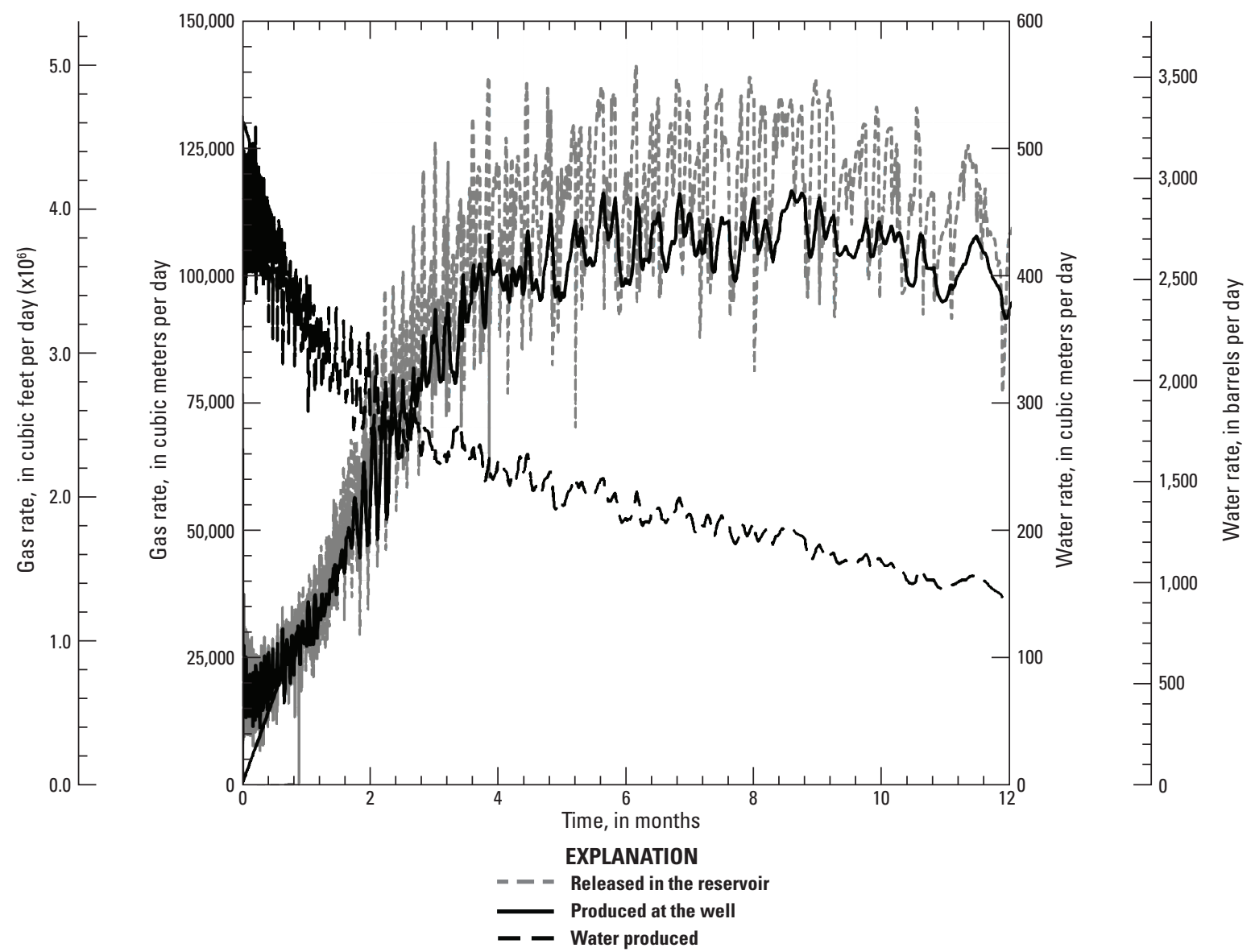

Figure 18. Predicted gas and water production from the Prudhoe Bay Unit (PBU) L-106 C-unit methane hydrate deposit for a constant bottom-hole pressure of 2.7 megapascals (MPa). The solid black and dotted grey curves represent the rate of gas produced at the wellhead and gas released in the reservoir respectively, and correspond to the left $y$-axis. The rate of water production is on the right (y-axis) and is indicated by the dashed black line.

inferred gas hydrate stability zone. As depicted in figure $5 C$ gas hydrates cannot exists outside of the zero contour line on the gas hydrate stability zone thickness map.

The next component of the gas hydrate petroleum system to be considered is the presence of suitable reservoir rocks within the limits of the gas hydrate stability zone, the characterization of which yielded the three AUs defined in this study. It is important to highlight that only gas hydrates lying below the permafrost section were assessed, thereby limiting the AUs to the stratigraphic interval below the base of the permafrost (fig. 4) and above the base of the gas hydrate stability zone (fig. $5 B$ ). This decision was based on the results of production modeling, as reviewed in the "Gas Hydrate Production Modeling" section of this report. The results show that gas hydrate depressurization production rates are severely retarded by low reservoir temperatures and the presence of ice within the permafrost section that restricts the propagation of a pressure front into the formation and the flow of gas to the borehole. It is also emphasized that free-gas potentially trapped below the gas hydrate stability zone was not assessed in this study.
As described in the "Reservoir Rocks" section of this report, the known gas hydrate accumulations within the Eileen trend along the western border of the PBU (figs. 7, 8 ) are limited to sandstone reservoirs in the Sagavanirktok Formation (fig. 6). In this study, however, a total of five Cretaceous and Tertiary sand-rich formations were assessed for gas hydrates. Stratigraphic nomenclature used here is the revised nomenclature of Mull and others (2003) for Cretaceous and Tertiary rocks on the North Slope, as follows: (1) reservoir quality rocks previously included within the Nanushuk Group (Corwin and Chandler Formations) are now assigned to the Nanushuk Formation; (2) Upper Cretaceous reservoir strata previously assigned to the Tuluvak Tongue of the Prince Creek Formation in the Colville Group are now included in the Tuluvak Formation; and (3) reservoir strata previously included in the Kogosukruk Tongue of the Prince Creek Formation (Colville Group), as well as strata previously assigned to the lower part of the Sagwon Member of the Sagavanirktok Formation, are now included in the Prince Creek Formation (fig. 6). The newly revised Tuluvak Formation and the Prince Creek Formation are separated by 


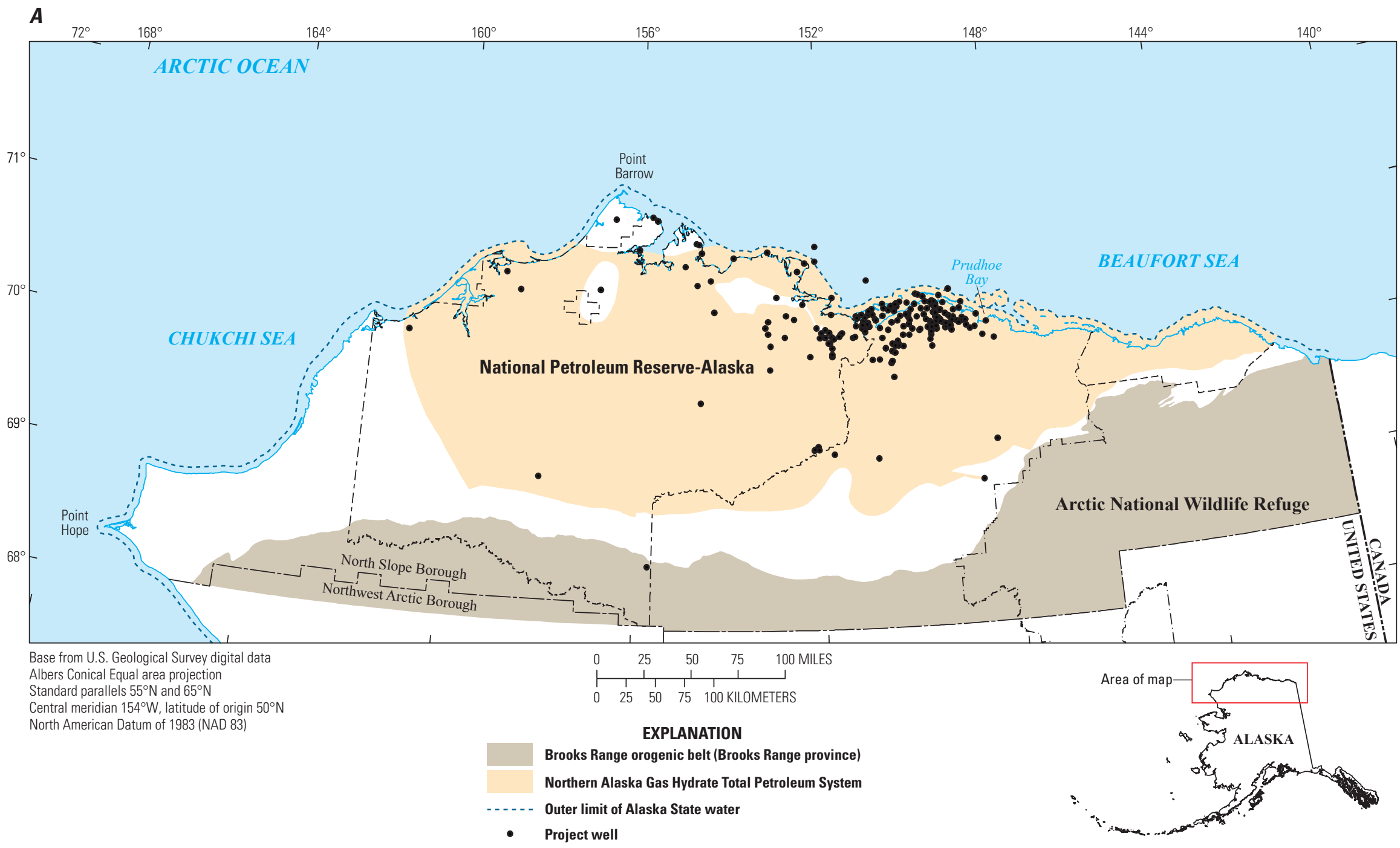

Figure 19. A, map of the Northern Alaska Gas Hydrate Total Petroleum System (TPS) (500102) (shaded in tan). $B$, map of the Northern Alaska Gas Hydrate TPS (shaded in $\tan$ ) and the gas hydrate stability zone thickness contours (in red) from figure $5 \mathrm{C}$. Contours in feet (ft). (NPRA, Natural Petroleum Reserve in Alaska; ANWR, Alaska National Wildlife Refuge) 
B

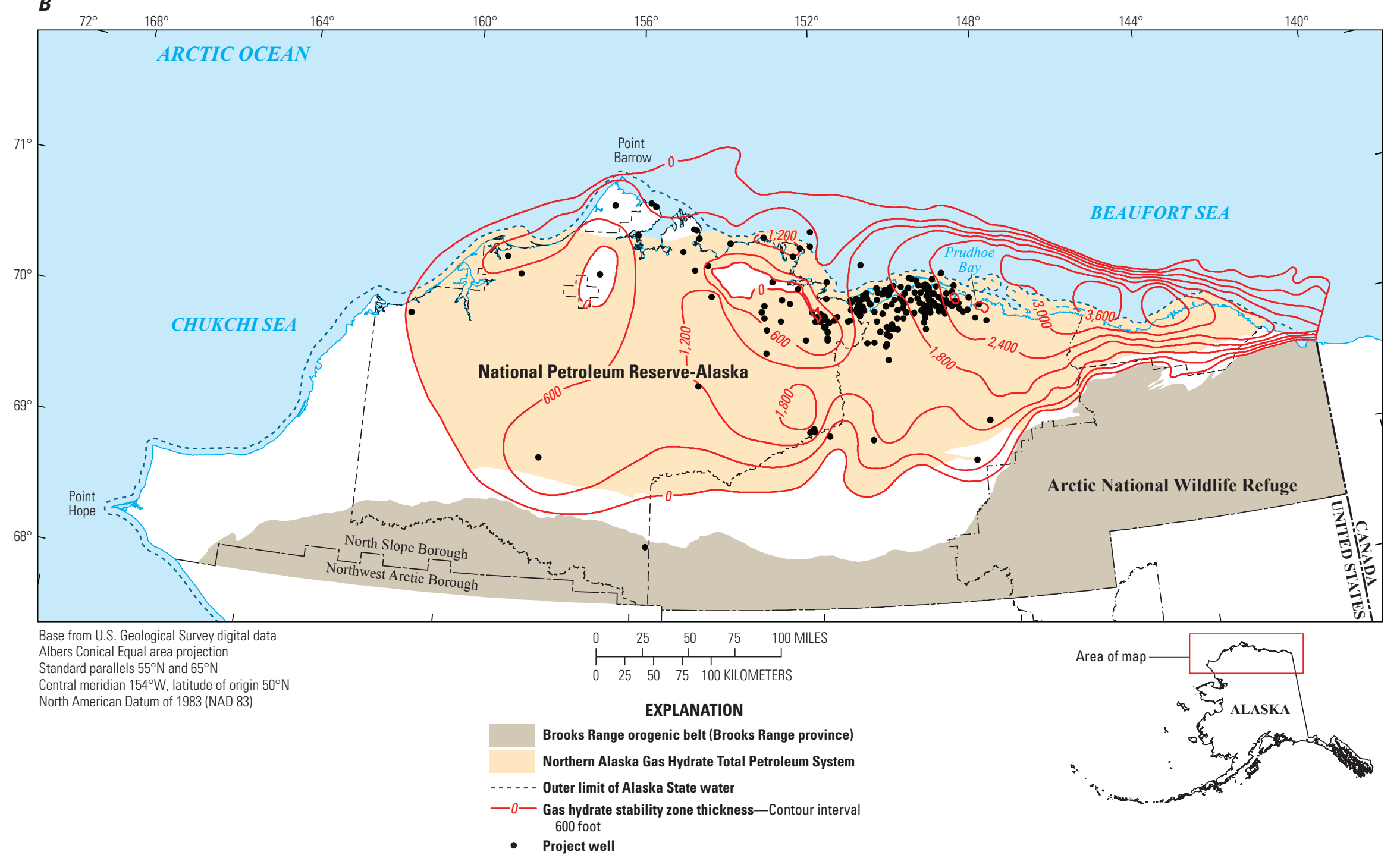

Figure 19. A, map of the Northern Alaska Gas Hydrate Total Petroleum System (TPS) (500102) (shaded in tan). B, map of the Northern Alaska Gas Hydrate TPS (shaded in $\operatorname{tan)}$ and the gas hydrate stability zone thickness contours (in red) from figure 5 C. Contours in feet (ft). (NPRA, Natural Petroleum Reserve in Alaska; ANWR, Alaska National Wildlife Refuge)-Continued 


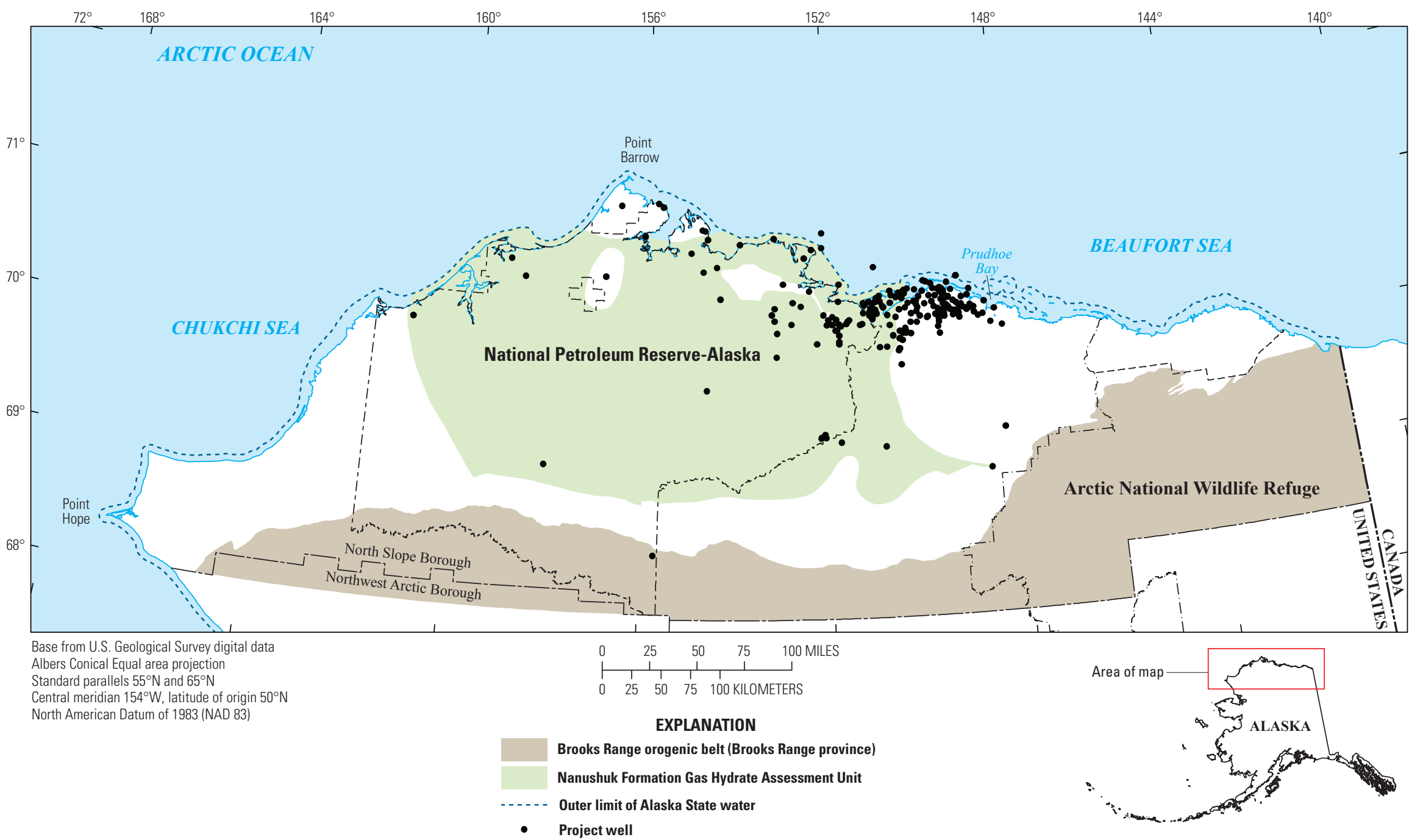

Figure 20. Map of the Nanushuk Formation Gas Hydrate Assessment Unit (AU) (50010203) (shaded in green). (NPRA, Natural Petroleum Reserve in Alaska; ANWR, Alaska National Wildlife Refuge) 


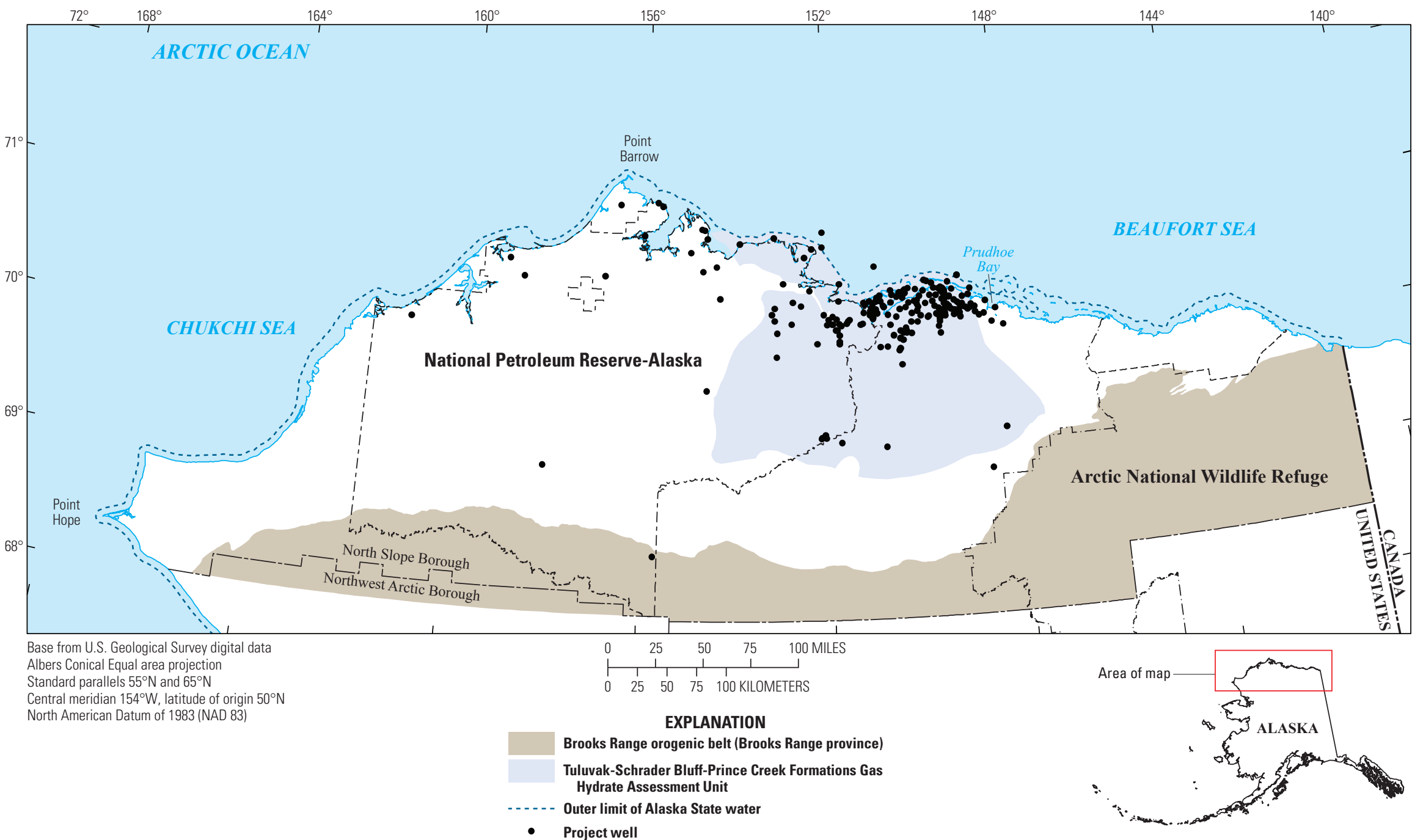

Figure 21. Map of the Tuluvak-Schrader Bluff-Prince Creek Formations Gas Hydrate Assessment Unit (AU) (50010202) (shaded in blue). (NPRA, Natural Petroleum Reserve in Alaska; ANWR, Alaska National Wildlife Refuge) 


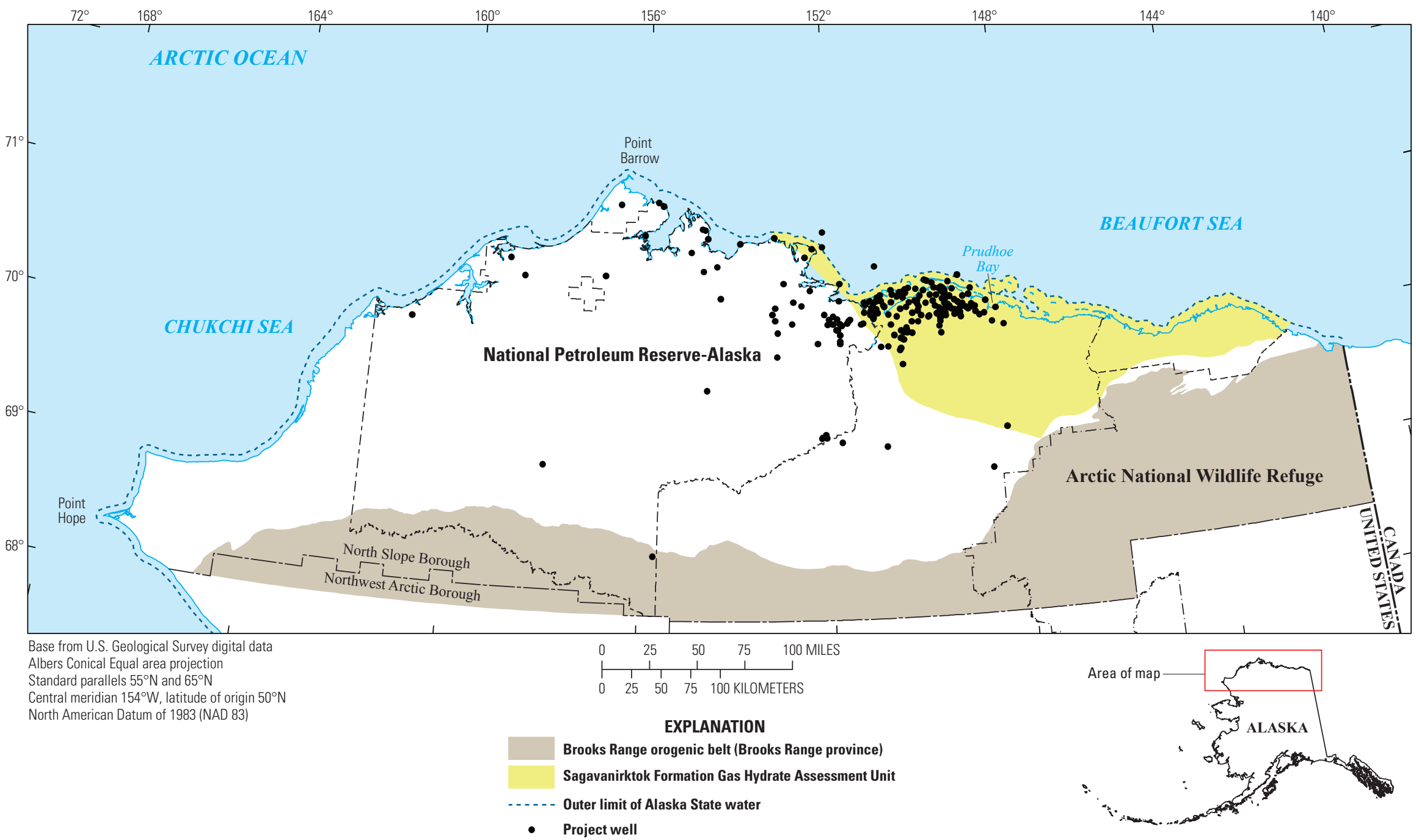

Figure 22. Map of the Sagavanirktok Formation Gas Hydrate Assessment Unit (AU) (50010201) (shaded in pale green). (NPRA, Natural Petroleum Reserve in Alaska; ANWR, Alaska National Wildlife Refuge) 
the Schrader Bluff Formation, a mostly marine unit composed of reservoir quality sandstone units and shale that can be as thick as $2,500 \mathrm{ft}(762 \mathrm{~m})$. Regional relations suggest a general northeasterly progradation of the Tuluvak Formation and overlying Schrader Bluff and Prince Creek Formations, which collectively appear to be genetically related, constitute a largescale sediment package of shallow-marine to marginal-marine facies and coastal-plain facies.

Stratigraphic nomenclature of Mull and others (2003) for Tertiary strata in the Sagavanirktok Formation also includes revisions to previous definitions and terminology of Gryc and others (1951) and Detterman and others (1975) for this formation. In Mull and others (2003), the Sagavanirktok Formation includes three members (ascending order): the Sagwon Member (revised definition), White Hills Member (newly defined), and the Franklin Bluffs Member (revised definition).

Gas source and gas migration are two of the more critical components of both the TPS and AUs. As part of the gas hydrate petroleum system assessment, geochemical analysis of samples recovered from wells that have penetrated known gas hydrate occurrences revealed a link between gas hydrate accumulations on the North Slope and more deeply buried conventional oil and gas accumulations, in which methane migration from depth has charged the reservoir rocks in the gas hydrate stability zone (Collett, 1993; Lorenson and others, 2011). Considering the apparent prolific nature of the hydrocarbon source rocks on the Alaska North Slope (Bird, 1998; Bird and Magoon, 1987; Houseknecht, 2003), it was assumed in this assessment that the gas within the undiscovered gas hydrate accumulations in each of the AUs is solely from more deeply buried thermogenic sources. The geochemical analysis of gas samples from wells and the distribution of known more deeply buried conventional oil and gas accumulations have also been used in this study to further characterize and constrain the occurrence and distribution of the potential gas hydrate accumulations on the North Slope as described in the "Undiscovered Gas Hydrate AccumulationsNumber of Accumulations" section of this report.

Because there is no production of gas from gas hydrates on the North Slope and only limited testing of hydrates in the Mount Elbert well (Hunter and others, 2011), the three AUs in the Northern Alaska Gas Hydrate TPS (fig. 19) (the Nanushuk Formation Gas Hydrate AU (fig. 20), the Tuluvak-Schrader Bluff-Prince Creek Formations Gas Hydrate AU (fig. 21), and the Sagavanirktok Formation Gas Hydrate AU (fig. 22)) are all considered to be hypothetical. The potential reservoir facies in the Tuluvak, Schrader Bluff, and Prince Creek Formations share a similar geographic distribution, so these formations are grouped together into a single AU.

The remainder of this section provides a summary of the geologic criteria and data used to define the physical distribution of the three AUs. The key geologic consideration that is discussed for each AU relates to the occurrence of potential gas hydrate reservoir sedimentary facies within the interval below the base of the overlying permafrost section and above the base of the gas hydrate stability zone.

Because of the long history of industry-led exploration activities and USGS resource assessments in northern Alaska, this study had access to a large number of pertinent published reports and databases. One of the more important sources of information was the various data sets published with the previously completed USGS assessments of unconventional and conventional resources in northern Alaska, including the following: (1) 1995 USGS Gas Hydrate Assessment (Collett, 1995); (2) 1999 Oil and Gas Resource Potential of the Arctic National Wildlife Refuge 1002 Area, Alaska (ANWR Assessment Team, U.S. Geological Survey, 1999); (3) 2002 Petroleum Resource Assessment of the National Petroleum Reserve in Alaska (Bird and Houseknecht, 2002); (4) 2005 Oil and Gas Assessment of Central North Slope, Alaska (Garrity and others, 2005); and (5) 2007 Geologic Assessment of Undiscovered Coalbed Gas Resources in Cretaceous and Tertiary Rocks, North Slope and Adjacent State Waters, Alaska (Roberts, 2008).

The USGS also maintains several specialized data sets that were used in this assessment. One of the most important data sets is a copy of the State of Alaska well-log database (Alaska Oil and Gas Conservation Commission, 2008) - this database contains the publicly available downhole log data from more than 3,000 North Slope exploratory and development wells. For the most part, log data from wells in Alaska are released by the State two years after the completion of a well. This well-log database was also used to develop an unpublished USGS Alaska formation "tops file" as maintained by Ken Bird (USGS, Menlo Park, California), Dave Houseknecht (USGS, Reston, Virginia), and Phil Nelson (USGS, Denver, Colorado). The USGS Alaska formation "tops file" contains listings of penetration depths of all the major geologic "markers" and formations tops encountered in about 400 wells as of December 1, 1998. This file was developed mostly as a product of the various USGS Alaska North Slope assessment studies.

A number of well-log correlation sections were developed as part of this study and other USGS assessments in northern Alaska (as listed above). Lewis and Collett (2013), for example, compiled a series of nine correlation sections, containing well-log data from more than 122 wells, extending from just west of the Colville River in NPRA and extending to the east near the Sagavanirktok River (fig. 23). These sections include (1) "well-log picks" for the tops of all the major formations and well-log markers, (2) depths of the well-log-inferred gas hydrate accumulations (including those within the Eileen and Tarn gas hydrate accumulation), (3) depths of the top and base of the gas hydrate stability zone, and (4) depths to the base of permafrost and (or) ice-bearing permafrost. Other important published well-log correlation sections were available from Molenaar and others (1987a) and Decker (2007). 


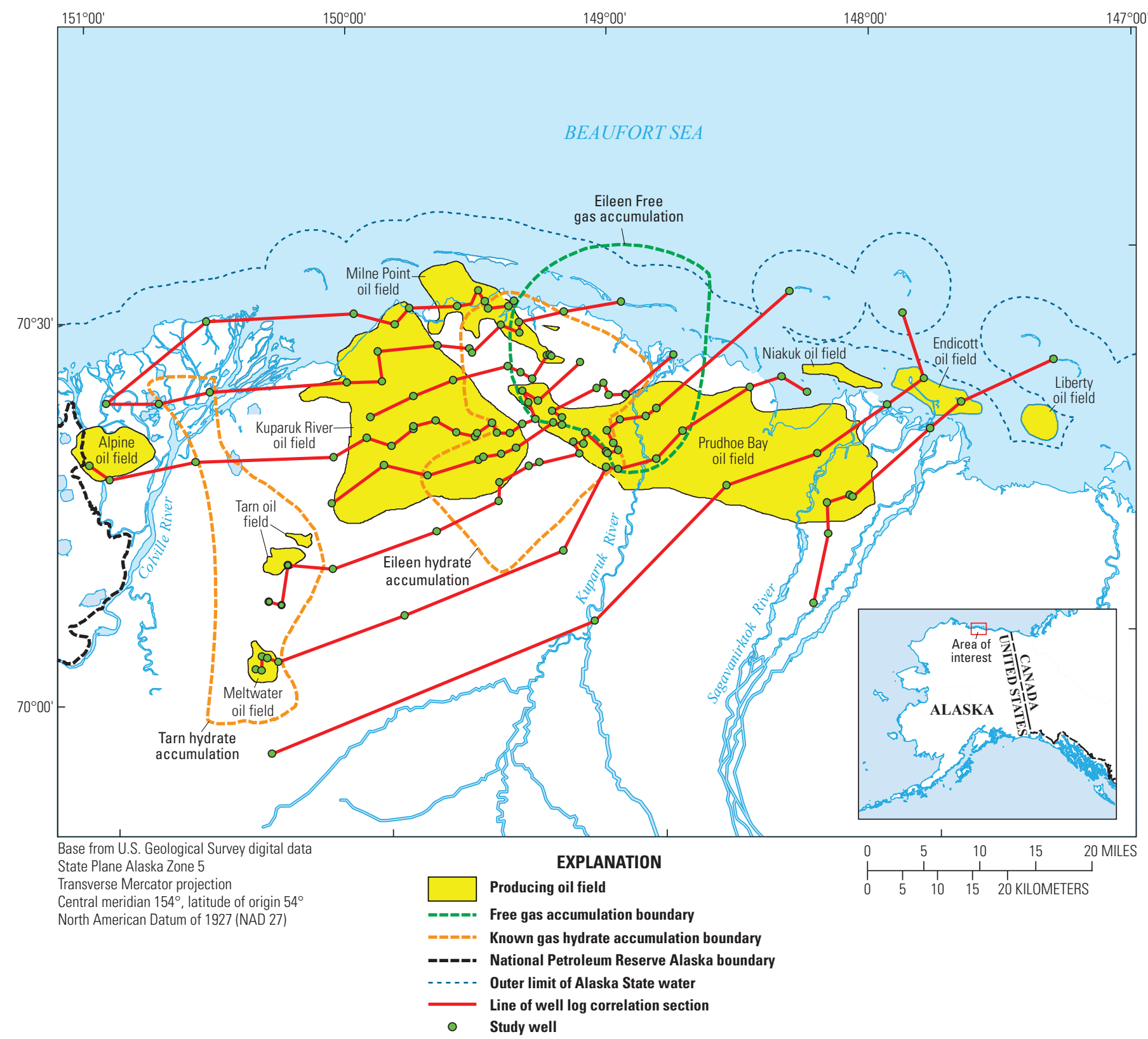

Figure 23. Map showing locations of well-log correlation sections within the greater Prudhoe Bay area as compiled by Lewis and Collett (2013).

This project also made use of several extensive grids of 2D seismic lines and 3D seismic volumes (fig. 24). As part of the U.S. Government-managed NPRA exploration program in the 1970s and 1980s, the USGS supervised the acquisition of more than 15,000 mi of 2D seismic data. Miller and others $(2000,2001)$ included reprocessed digital seismic data for a series of regional reference seismic lines (roughly 4,200 line-miles), which formed a $20 \times 20$-mi grid covering the entire NPRA (fig. 24). The USGS NPRA seismic data grid was used in this assessment to help set the western and southern limits of the three AUs. This assessment also had access to an additional set of multichannel, seismic-reflection lines from ANWR (fig. 24), which were recorded as part of a resource assessment study conducted by the USGS and others in the 1980s (Bird and Magoon, 1987). This seismic data set helped to define the southeastern limits of the Sagavanirktok Formation Gas Hydrate AU (discussed later in this report).

As described in the "Undiscovered Gas Hydrate Accumulations - Sizes of Accumulations" and "Undiscovered Gas Hydrate Accumulations-Number of Accumulations" sections of this report, this study also relied on numerous 3D seismic volumes to help define the limits of the AUs 


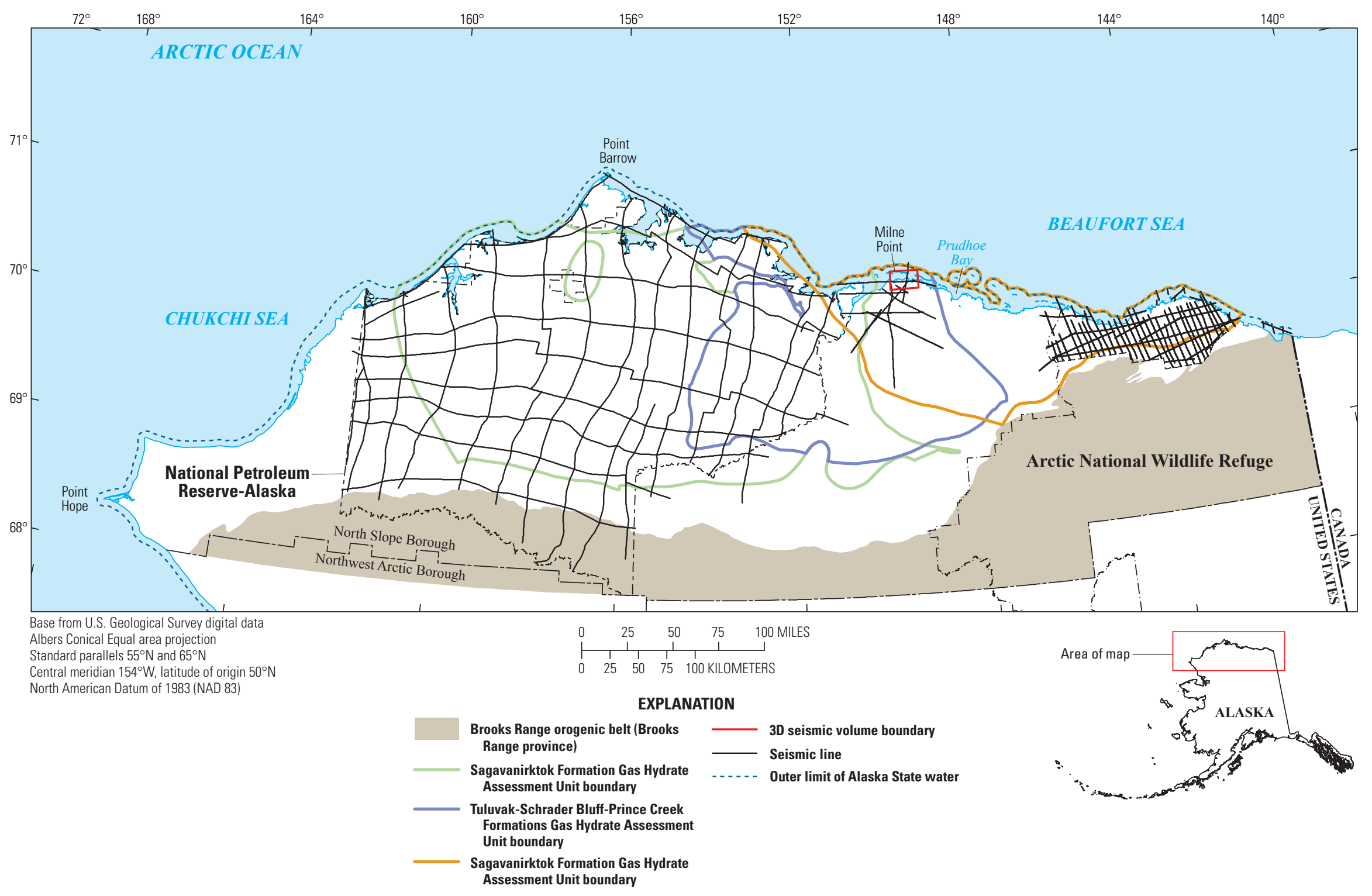

Figure 24. Map of 2D and 3D seismic profiles, the interpretation of which were used as the base data for this assessment of undiscovered gas hydrate resources on the Alaska North Slope. Most of the 2D seismic lines depicted in or near NPRA are from Miller and others $(2000,2001)$ and the 2D seismic lines shown in ANWR are from Bird and Magoon (1987). Also shown is the outline of the Milne Point unit 3D seismic volume used to identify and map gas hydrate prospects. The NPRA 3D seismic volumes used in this assessment have not been shown in this figure for confidentiality reasons. (NPRA, National Petroleum Reserve in Alaska; ANWR, Arctic National Wildlife refuge) 
and to determine the size and number of undiscovered gas hydrate accumulations. As discussed earlier, the 3D seismic data volume from the MPU covering an area of $155 \mathrm{mi}^{2}$ (figs. 10, 24) (as released to the USGS by BP Exploration Alaska, Inc.) was used to develop and document seismic methods for identifying a series of nine gas hydrate prospects (accumulations) in the MPU (Lee and others, 2009, 2011; Inks and others, 2009). The USGS was also given access by BLM to four additional 3D seismic volumes from NPRA. These additional seismic data volumes from NPRA covered an area of $729 \mathrm{mi}^{2}$, were used under strict data-confidentiality rules, and cannot be released for public disclosure (subject to 43 CFR 3152.6 (a) (b), 43 CFR 3152.7 (a) (2), and 43 CFR 3100.4). To maintain data confidentiality, no portion of the data sets, location information, or names of the NPRA seismic data volumes were used in this report. For descriptive purposes, the four 3D seismic-data volumes were named NPRA 3D Seismic No. 1 through NPRA 3D Seismic No. 4. These four seismic-data volumes provided critical insight to the size and number of undiscovered gas hydrate accumulations in the Nanushuk Formation Gas Hydrate AU and the Tuluvak-Schrader Bluff-Prince Creek Formations Gas Hydrate AU.

The Northern Alaska Gas Hydrate TPS is defined here (figs. $19 A-B$ ) to include the area of the Alaska North Slope and adjacent State waters underlain by Cretaceous and Tertiary strata that (1) are in the interval between the base of the permafrost (fig. 4) and above the base of the gas hydrate stability zone (fig. $5 B$ ), and (2) are interpreted to contain reservoir quality sandstone deposits with the potential for containing gas hydrate. The TPS thus includes a significant part of the National Petroleum Reserve in Alaska (NPRA), and limited lands in the Arctic National Wildlife Refuge (ANWR). The southern onshore boundary of the TPS is defined by the mapped intersection of Cretaceous continental deposits and the base of permafrost within the mapped zone of gas hydrate stability. The eastern and western limits of the TPS extend to the limits of the Topset Play in the 1001 Area of ANWR (ANWR Assessment Team, U.S. Geological Survey, 1999) and the Brookian Topset Play in NPRA (Bird and Houseknecht, 2002). The offshore limits of the TPS extended to the boundary of the Alaskan State waters.

Recent work summarized by Walsh and others (2007) led to the conclusion that the East Barrow and Walakpa gas fields, located near the village of Barrow, may extend up into the overlying methane hydrate stability zone, thus opening the possibility that gas hydrate may exist in the crest of these two conventional gas fields, neither of which fall within the AUs as defined in this assessment. However, due to the lack of well penetrations in the updip portion of the Walakpa field, it has not been possible to more thoroughly evaluate the occurrence of gas hydrate in this field. There is also no direct geologic evidence for the presence of gas hydrate in the East Barrow gas field. It was therefore decided not to include the Barrow or Walakpa reservoirs in this assessment.

\section{6.a.1. Nanushuk Formation Gas Hydrate Assessment Unit}

The Nanushuk Formation Gas Hydrate AU encompasses just over 19,816,320 acres (roughly 30,963 $\mathrm{mi}^{2}$ ) in the western and central parts of the North Slope (fig. 20). The western and southern limits of the Nanushuk Formation Gas Hydrate AU are defined by the intersection with the base of the permafrost section, within the limits of gas hydrate stability zone, and the mapped limit of the Nanushuk Formation reservoirs. The eastern limit of the $\mathrm{AU}$ is defined by the intersection with the base of the gas hydrate stability zone and mapped limit of Nanushuk Formation reservoirs and other older reservoir sections. The northern boundary of the AU is defined mostly by the limit of the Alaska State Waters (from the mean high water line out to 3 nautical miles).

In general, the Nanushuk Formation Gas Hydrate AU is limited to mostly the topset seismic facies as identified from the USGS regional 2D seismic lines and available 3D seismic volumes in NPRA and to the south along the Brooks Range Foothills. Well-log picks for the Nanushuk Formation from 124 wells in the USGS Alaska formation "tops file," along with several project generated well-log correlation sections, have been used to further refine the limits of this AU. Most of the AU is coincident with (1) the Nanushuk Formation Coalbed Gas AU (Roberts, 2008); (2) the conventional Brookian Topset, Brookian Topset Structural, Brookian Clinoform Central, Brookian Clinoform South Shallow, and Brookian Clinoform South Deep AUs from the 2002 Petroleum Resource Assessment of the National Petroleum Reserve in Alaska (Bird and Houseknecht, 2002); and (3) portions of the conventional Brookian Topset, Brookian Clinoform, Brookian Topset Structural North, Brookian Topset Structural South, Brookian Clinoform Structural North, and Brookian Clinoform Structural South AUs from the 2005 Oil and Gas Assessment of Central North Slope, Alaska (Garrity and others, 2005) (see table 2).

The Nanushuk Formation (fig. 6), which is Albian to Cenomanian in age, is exposed along an outcrop belt about $20 \mathrm{mi}$ wide that extends for nearly $400 \mathrm{mi}$ from west to east in the Foothills Province north of the Brooks Range (figs. 1A-B). The Nanushuk Formation overlies the predominantly marine Torok Formation. In the subsurface, the Nanushuk extends across the coastal plain, covering much of the western and central parts of the North Slope; the thickest observed section is $6,150 \mathrm{ft}(1,874 \mathrm{~m}$ ) in the Tunalik 1 well (as documented in the USGS Alaska formation "tops file"). The structural setting of the Nanushuk Formation within the AU coincides roughly with the Alaska North Slope physiographic provinces that are characterized by east-west-trending detachment folds in the foothills and broad, low-amplitude anticlines in the coastal plain (fig. $1 B$ ) to the north (Potter and Moore, 2003). Structure contour maps on the top of the Nanushuk in the coastal plain areas indicate that the rocks dip gently southward in the westcentral and western parts of the AU, and shift to east and southeasterly dips in the eastern part of the AU (Potter and Moore, 2003). 
Table 2. Cross-reference of the gas hydrate assessment units with USGS conventional assessment units in northern Alaska (ANWR Assessment Team, U.S. Geological Survey, 1999; Bird and Houseknecht, 2002; Garrity and others, 2005).

\begin{tabular}{|c|c|}
\hline ANWR Assessment ${ }^{1}$ & $\begin{array}{c}\text { Gas Hydrate } \\
\text { Assessment Unit }\end{array}$ \\
\hline Topset play & SAG \\
\hline Thin skinned trus & SAG \\
\hline Turbidite play & SAG \\
\hline Wedge play & SAG \\
\hline Central North Slope Assessment ${ }^{2}$ & $\begin{array}{c}\text { Gas Hydrate } \\
\text { Assessment Unit }\end{array}$ \\
\hline Brookian Topset & NAN/TSBPC/SAG \\
\hline Brookian Clinoform & NAN/TSBPC/SAG \\
\hline Brookian Topset Structural North & NAN/TSBPC/SAG \\
\hline Brookian Topset Structural South & NAN/TSBPC/SAG \\
\hline Brookian Cinoform Structural North & NAN/TSBPC/SAG \\
\hline Brookian Cinoform Structural South & NAN/TSBPC/SAG \\
\hline NPRA Assessment ${ }^{3}$ & $\begin{array}{c}\text { Gas Hydrate } \\
\text { Assessment Unit }\end{array}$ \\
\hline $\begin{array}{l}\text { Brookian Topset } \\
\text { Brookian Topset Structural } \\
\text { Brookian Cinoform North } \\
\text { Brookian Cinoform Central } \\
\text { Brookian Cinoform South Shallow } \\
\text { Brookian Cinoform South Deep }\end{array}$ & $\begin{array}{l}\text { NAN/TSBPC/SAG } \\
\text { NAN/TSBPC } \\
\text { NAN/TSBPC/SAG } \\
\text { NAN/TSBPC } \\
\text { NAN/TSBPC } \\
\text { NAN/TSBPC }\end{array}$ \\
\hline \multicolumn{2}{|l|}{ Key: } \\
\hline \multicolumn{2}{|c|}{$\begin{array}{l}\text { TSBPC }=\text { Tuluvak-Schrader Bluff-Prince Creek Formations Gas Hydrate } \\
\text { Assessment Unit }\end{array}$} \\
\hline \multicolumn{2}{|c|}{ SAG $=$ Sagavanirktok Formation Gas Hydrate Assessment Unit } \\
\hline \multicolumn{2}{|c|}{$\begin{array}{l}1002 \text { area, Alaska, } 1999 \text { (ANWR Assessment Team, U.S. Geological } \\
\text { Survey, 1999). }\end{array}$} \\
\hline \multicolumn{2}{|c|}{$\begin{array}{l}{ }^{2} \text { Oil and gas assessment of central North Slope, Alaska, } 2005 \text { (Garrity } \\
\text { and others, 2005). }\end{array}$} \\
\hline${ }^{3}$ Petroleum resource assessment of the & 1 Petroleum Reserve in \\
\hline
\end{tabular}

\section{6.a.2. Tuluvak-Schrader Bluff-Prince Creek Formations Gas Hydrate Assessment Unit}

The Tuluvak-Schrader Bluff-Prince Creek Formations Gas Hydrate AU encompasses more than 9,179,520 acres (roughly $14,343 \mathrm{mi}^{2}$ ) in the central and east-central parts of the North Slope (fig. 21). Because of their genetic similarities (as previously discussed) the Tuluvak, Schrader Bluff, and Prince Creek Formations (fig. 6) were assessed jointly as one AU. The western and southern limits of the AU are marked by the intersections (subcrop) of the Tuluvak, Schrader Bluff, and Prince Creek reservoir facies with the base of the permafrost section within the limits of the gas hydrate stability zone. The eastern limit of the $\mathrm{AU}$ is defined by the intersection with the base of the gas hydrate stability zone and the mapped limit of Prince Creek Formation reservoirs. The western permafrostsubcrop and eastern limit of the Tuluvak, Schrader Bluff, and Prince Creek reservoir facies were also mapped with the available NPRA 2D and 3D seismic data sets as described above. Although strata also interpreted to be equivalent to the Prince Creek and Tuluvak Formations have been reported in outcrops as far west as the Utukok River near Corwin Bluff (fig. 1A) (Mull and others, 2006), the AU boundary was not extended to that area because neither formation has been identified in wells that far west. The northern boundary of the AU is almost entirely defined by the limit of the Alaska State Waters (from the mean high water line out to three nautical miles; fig. 24).

Much like the Nanushuk Formation Gas Hydrate AU, the Tuluvak-Schrader Bluff-Prince Creek Formations Gas Hydrate AU is mostly limited to the topset seismic facies, as identified from the USGS regional 2D seismic lines and available 3D seismic volumes in NPRA and to the area east of the Colville River (fig. 24). Well-log picks for the Tuluvak, Schrader Bluff, and Prince Creek Formations from 94 wells in the USGS Alaska formation "tops file" were used to further define the limits of this AU. Project-developed, well-log correlation sections (Lewis and Collett, 2013) and the Umiat field to Milne Point field Brookian sequence stratigraphic correlation section from Decker (2007) provided valuable insight into the distribution of the reservoir facies within the AU. It is important to emphasize that the well-log-inferred gas hydrates of the "Tarn accumulation" along the western border of the KRU (fig. 23; Collett, 2002) are within reservoir rocks of the Tuluvak-Schrader Bluff-Prince Creek Formations Gas Hydrate AU (see the "Reservoir Rocks" section of this report).

The Prince Creek and Tuluvak Formations Coalbed Gas AU of Roberts (2008) falls almost entirely within the limits of the Tuluvak-Schrader Bluff-Prince Creek Formations Gas Hydrate AU. The Tuluvak-Schrader Bluff-Prince Creek Formations Gas Hydrate AU also includes portions of the conventional Brookian Topset, Brookian Topset Structural, Brookian Clinoform North, Brookian Clinoform Central, Brookian Clinoform South Shallow, and Brookian Clinoform South Shallow AUs from the 2002 Petroleum Resource Assessment of the National Petroleum Reserve in Alaska (Bird and Houseknecht, 2002), along with portions of the conventional Brookian Topset, Brookian Clinoform, Brookian Topset Structural North, Brookian Topset Structural South, Brookian Clinoform Structural North and, Brookian Clinoform Structural South AUs from the 2005 Oil and Gas Assessment of Central North Slope, Alaska (Garrity and others, 2005) as summarized in table 2.

As previously discussed, the Tuluvak, Schrader Bluff, and Prince Creek Formations have been jointly assessed in this report. The Tuluvak Formation (fig. 6) is Turonian-Coniacian in age and outcrops generally consist of conglomerate, sandstone, shale, carbonaceous shale, and coal. The Tuluvak Formation for the most part is poorly exposed in outcrop, but subsurface well-log data indicate thicknesses range from $140 \mathrm{ft}(43 \mathrm{~m})$ thick in the Colville Delta 1 well to as much as $1,450 \mathrm{ft}(442 \mathrm{~m})$ thick in the Aufeis Unit 1 well (as documented in the USGS Alaska formation "tops file"). The age of the Schrader Bluff Formation is Santonian to 
Maastrichtian. The unit consists dominantly of marine sandstones and shale, with the upper part mostly of shallowmarine sandstones that grade upward into sandstones of the overlying Prince Creek Formation (fig. 6). The thickness of the Schrader Bluff Formation is as much as roughly 2,500 ft (roughly $762 \mathrm{~m}$ ) in the Chandler River region and decreases northward to about $1,800 \mathrm{ft}(549 \mathrm{~m})$ in the Umiat area (fig. 1A). The Prince Creek Formation (fig. 6) is Campanian through Paleocene in age, and is characterized in outcrop by interbedded conglomerate, sandstone, mudstone, carbonaceous shale, and coal; no complete section, however, is exposed. Because of its lithologic similarity with the underlying Schrader Bluff Formation, the two formations are difficult to separate in the subsurface. The aggregate thickness of the undifferentiated Prince Creek and Schrader Bluff Formations ranges from about $100 \mathrm{ft}(30 \mathrm{~m})$ to almost 5,000 ft $(1,524 \mathrm{~m})$. The structural characteristics of this AU are similar to those described above in the Nanushuk Formation Gas Hydrate AU, with east-west-trending detachment folds in the foothills regions and only slightly deformed and gently east-dipping strata in the coastal plain.

\section{6.a.3. Sagavanirktok Formation Gas Hydrate Assessment Unit}

The Sagavanirktok Formation Gas Hydrate AU (fig. 22) encompasses just over 6,776,320 acres (roughly 10,588 $\mathrm{mi}^{2}$ ) in the east-central part of the North Slope (fig. $1 A-B$ ). The western and southern boundaries of the AU represent the subcrop of the Sagavanirktok Formation reservoir facies with the base of the permafrost section within the limits of the gas hydrate stability zone based on drill-hole data and a limited number of 2D seismic lines (fig. 24). Well-log picks for the Sagavanirktok Formation from 253 wells in the USGS Alaska formation "tops file" extended the eastern boundary of the AU to the Canning River (fig. 1A). Because of the lack of drilling in ANWR, 2D seismic data were used to estimate the downdip intersection of the Sagavanirktok reservoir facies with the gas hydrate stability zone. The northern boundary of the AU is defined mostly by the limit of the Alaska State Waters (from the mean high water line out to 3 nautical miles).

Much like the case for the other two assessed gas hydrate AUs, the Sagavanirktok Formation Gas Hydrate AU is mostly limited to the topset seismic facies as identified from the USGS regional 2D seismic lines. Project-developed well-log correlation sections (Lewis and Collett, 2013), along with the published well-log correlation sections from Decker (2007), provided basic data for outlining the distribution of the reservoir facies in this AU. It is important to note the well-log inferred and cored gas hydrates in the "Eileen accumulation" along the western border of the PBU (fig. 23) (Collett, 1993, 2002) are within reservoir rocks of the Sagavanirktok Formation Gas Hydrate AU (see "Reservoir Rocks" section of this report).
Most of the Sagavanirktok Formation Gas Hydrate AU is coincident with (1) the Sagavanirktok Formation Coalbed Gas AU (Roberts, 2008); (2) the conventional Brookian Topset and Brookian Clinoform North AUs that were defined for the 2002 Petroleum Resource Assessment of the National Petroleum Reserve in Alaska (Bird and Houseknecht, 2002); (3) portions of the conventional Brookian Topset, Brookian Clinoform, Brookian Topset Structural North, Brookian Topset Structural South, Brookian Clinoform Structural North and, Brookian Clinoform Structural South AUs that were defined for 2005 Oil and Gas Assessment of Central North Slope, Alaska (Garrity and others, 2005); and (4) portions of the Topset Play, Thin Skinned Thrust-Belt Play, Turbidite Play, and Wedge Play that were defined for the 1999 Arctic National Wildlife Refuge 1002 area assessment (ANWR Assessment Team, U.S. Geological Survey, 1999) (see table 2).

The Sagavanirktok Formation (fig. 6) is PaleoceneMiocene in age and generally consists of conglomerate, sandstone, mudstone, carbonaceous shale, and coal. It was deposited in a northeast-prograding deltaic system (Molenaar, 1983), and becomes younger from southwest to northeast across the AU. The formation also thickens from the southwest to the northeast, with a maximum thickness of about $9,000 \mathrm{ft}$ $(2,743 \mathrm{~m})$ along the northeastern boundary of the AU.

Structurally, most of the AU lies north of the detachment folds that characterize the Foothills province (fig. $1 B$ ), although the Sagavanirktok Formation is exposed on the limbs of gently folded anticlines along the southeastern boundary of the AU. In the greater PBU area, the Sagavanirktok Formation is also cut by faults that are generally downthrown to the east (displacements from 50 to $200 \mathrm{ft}$; 15 to $61 \mathrm{~m}$ ) that are also believed to provide pathways for gas migration from deeply buried hydrocarbon sources into the overlying hydrate-bearing reservoirs as reviewed in "Section 4.c. Gas Source and Migration" of this report.

\section{6.b. Assessment Unit Probabilities}

After defining the limits of the three gas hydrate AUs, the assessment unit probabilities for each AU was determined. The assessment-unit probabilities as determined for each of the AUs in this study (as further reviewed in the Assessment-Data Form section of this report) relate a series of geologic risks associated with the existence of gas hydrate in each the AUs. In this assessment, three risking elements (attributes) of charge, rocks, and timing address the question of the probability of occurrence of at least one gas hydrate accumulation of minimum size, somewhere in the AU, that has the potential to be added to reserves (Schmoker and Klett, 2005). Each element in this risking structure applies to the AU as a whole, and each geologic element in an AU is reasonably homogeneous in terms of charge, rocks, and timing. In this assessment, the combination of geologic probabilities and the number and size of undiscovered accumulations (as reviewed 
in the next two sections and detailed in the accompanying appendices) yield the probability distribution for the amount of technically producible gas stored within the gas hydrate accumulations in each AU.

\section{6.c. Undiscovered Gas Hydrate Accumulations-Sizes of Accumulations}

Two of the critical components of the USGS assessment methodology are the accurate prediction of (1) the expected size and (2) the number of undiscovered hydrocarbon accumulations. This assessment of the gas hydrate resources on the North Slope relied heavily on the analysis of industryacquired three-dimensional seismic data, which used to characterize the size, number, and distribution of gas hydrate accumulations in each of the three AUs.

The results of the MPU gas hydrate 3D seismic prospecting study of Inks and others (2009), as reviewed in the "Reservoir Rocks" section of this report, provided the starting point for predicting the size of undiscovered gas hydrate accumulations on the North Slope. Inks and others (2009) presented a seismic-evaluation workflow designed to identify gas hydrate prospects (accumulations) and to estimate the volume of gas within the seismic-inferred gas hydrate accumulations. They identified a total of 14 seismic-inferred gas hydrate accumulations within the MPU (fig. 10) and estimated the in-place volume of gas within each accumulation (table 3). The identification of gas hydrate in the sandstone parts of the Sagavanirktok Formation by Inks and others (2009) was based primarily on seismic character analysis and correlation with well-log responses.

Rock-physics modeling and seismic trace modeling by Lee and others (2009) were used to establish seismic attributes for various types of gas hydrate accumulations. Modeled seismic amplitudes are small at relatively low gas hydrate saturations near 40 percent, and become larger with increasing gas hydrate saturations. In this study, a large positive seismic amplitude response signified highly saturated gas hydratebearing sediments. The modeling of Lee and others (2009) documented that the quality (that is, mostly frequency content) of the MPU 3D seismic volume limited the identification of gas hydrate occurrences to a minimum thickness of roughly $25 \mathrm{ft}$ (roughly $8 \mathrm{~m}$ ) and a minimum saturation of roughly 40 percent gas hydrate; gas hydrate occurrences below these values could not be identified with the $3 \mathrm{D}$ volume used in this study.

To calculate gas hydrate saturations and thicknesses of the gas hydrate accumulations in the MPU, the "thin-bed" modeling approach as described by Lee and others (2009) and Inks and others (2009) was used. For each inferred gas hydrate occurrence in this modeling approach, a time isochron of the wavelet from peak to trough was calculated, and the amplitudes of both the peak and trough were extracted. In each case, the seismic amplitude of the peak event and the travel-time between the peak and trough were used to calculate the thickness of the hydrate-bearing unit and the gas hydrate saturation within each accumulation (fig. 25A-B). This information was then used to compute the in-place volume of gas within each of the seismic inferred gas hydrate accumulations in the MPU (fig. 10, table 3). For this study, statistical distributions for bulk rock volume, sediment porosity, gas hydrate saturation, and net-to-gross reservoir thickness were used and applied based on specific ranges of values for each of the individual gas hydrate intervals examined in this study. Volumetric calculations using a standard Monte Carlo simulation method were performed for each seismic-inferred gas hydrate accumulation. The Monte-Carlo-derived median in-place gas volumes calculated for each of the gas hydrate accumulations in the MPU (table 3) were taken forward in the assessment process as the primary information on the expected size of the gas hydrate accumulations. These calculated volumes thus represent one set of potential analogs for undiscovered gas hydrate accumulations within areas with no 3D seismic data coverage.

To expand the database of analog gas hydrate accumulations, four additional 3D seismic volumes from NPRA were subjected to the same gas hydrate prospecting protocol and volumetric analysis as applied to the MPU 3D seismic volume. As described in the "Northern Alaska Gas Hydrate Total Petroleum System and Assessment Units" section, the 3D seismic volumes from NPRA were used under strict confidentiality rules, and only the number of gas hydrate accumulations, size of each accumulation, and volume of gas within each accumulation are included in this report (table 3).

In most cases, the conventional USGS assessment methodology only considers the size of the oil and (or) gas accumulation being assessed in terms of technical recoverable resources; the size of the accumulation is normally obtained from historical production data in the AU or an appropriate analog. As discussed in the "Gas Hydrate Production Analysis" section of this report, there has been no confirmed, sustained production of gas from gas hydrate anywhere in the world. Thus, the next step in the Alaska gas hydrate assessment was to ascertain how much of the in-place gas within the 3D seismic-inferred gas hydrate accumulations could be technically produced (table 3 ). The first approach used in this assessment to calculate percent of gas that can be recovered from a gas hydrate accumulation was relatively straightforward and based mostly on simple reservoir engineering concepts. As a starting point, it was assumed that gas hydrate dissociation in the annular space around the producing well is complete and that the dissociation front moves away from the borehole as production continues through time (that is, no gas hydrate remaining as isolated pockets or lenses in the annular space).

The borehole annular volume, which was previously filled with gas hydrate, is now filled with a likely mixture of water and gas that has evolved from the dissociated gas hydrate. But if it is assumed that the annular volume is completely filled with gas from dissociated hydrate (no water) at abandonment, all of the water and other gas released 
Table 3. List of 3D seismic imaged gas hydrate accumulations in the Milne Point Unit and the National Petroleum Reserve in Alaska, listed by the name of the accumulation and associated gas hydrate assessment unit. Also listed is the areal size of each accumulation along with the estimated median in-place and technical recoverable volume of gas within each accumulation (see figs. 27, 28).

[mi², square miles; $\mathrm{km}^{2}$, square kilometers; bcf, billion cubic feet]

\begin{tabular}{|c|c|c|c|c|c|c|c|}
\hline $\begin{array}{l}\text { Milne Point Unit- } \\
\text { Gas hydrate accumulation }\end{array}$ & Formation & $\begin{array}{l}\text { Area } \\
\left(\mathrm{mi}^{2}\right)\end{array}$ & $\begin{array}{l}\text { Area } \\
\left(\mathrm{km}^{2}\right)\end{array}$ & $\begin{array}{c}\text { Area } \\
\text { (acres) }\end{array}$ & $\begin{array}{c}\text { Gas hydrate } \\
\text { assessmnet unit }\end{array}$ & $\begin{array}{c}\text { Median in-place } \\
\text { volume of gas } \\
\text { (bcf) }\end{array}$ & $\begin{array}{l}\text { Median technical } \\
\text { recoverable volume } \\
\text { of gas } \\
\text { (bcf) }\end{array}$ \\
\hline Uncompahgre Peak & Sagavanirktok & 0.3 & 0.8 & 167 & SAG & 11 & 9 \\
\hline Pikes Peak & Sagavanirktok & 0.5 & 1.3 & 298 & $\mathrm{SAG}$ & 13 & 11 \\
\hline Redcloud Peak & Sagavanirktok & 0.3 & 0.8 & 194 & SAG & 18 & 15 \\
\hline Maroon Peak & Sagavanirktok & 0.6 & 1.6 & 375 & SAG & 33 & 28 \\
\hline Mt. Princeton & Sagavanirktok & 0.7 & 1.8 & 449 & SAG & 38 & 32 \\
\hline Mt. Bierstadt & Sagavanirktok & 0.5 & 1.3 & 332 & SAG & 42 & 36 \\
\hline Mt. Sneffels & Sagavanirktok & 0.8 & 2.1 & 516 & SAG & 46 & 39 \\
\hline Mt. Elbert "D" & Sagavanirktok & 0.4 & 1.0 & 267 & SAG & 52 & 44 \\
\hline Mt. Antero & Sagavanirktok & 1.5 & 3.9 & 955 & SAG & 75 & 64 \\
\hline Long's Peak & Schrader Bluff & 1.7 & 4.42 & 1,085 & TSBPC & 33 & 28 \\
\hline Windom Peak & Prince Creek & 1.6 & 4.1 & 1,007 & TSBPC & 39 & 33 \\
\hline Mt. Columbia & Tuluvak & 4.3 & 11.2 & 2,757 & TSBPC & 132 & 112 \\
\hline Humboldt Peak & Prince Creek & 5.9 & 15.2 & 3,760 & TSBPC & 141 & 120 \\
\hline Mt. Massive & Tuluvak & 6.9 & 17.7 & 4,384 & TSBPC & 190 & 162 \\
\hline Sunlight Peak & Prince Creek & 8.9 & 23.2 & 5,725 & TSBPC & 201 & 171 \\
\hline Mt. Harvard & Tuluvak & 7.9 & 20.6 & 5,080 & TSBPC & 210 & 179 \\
\hline Mt. Bross & Tuluvak & 11.6 & 29.9 & 7,397 & TSBPC & 293 & 249 \\
\hline Kit Carson Peak & Tuluvak & 12.8 & 33.2 & 8,206 & TSBPC & 382 & 325 \\
\hline Mt. Evans & Tuluvak & 22.9 & 59.3 & 14,651 & TSBPC & 611 & 519 \\
\hline
\end{tabular}

NAN = Nanushuk Formation Gas Hydrate Assessment Unit

TSBPC $=$ Tuluvak-Schrader Bluff-Prince Creek Formations Gas Hydrate Assessment Unit

$\mathrm{SAG}=$ Sagavanirktok Formation Gas Hydrate Assessment Unit

from the hydrate must have been produced up the wellbore. As shown in figure 26, at a well-abandonment pressure of 25 percent of the initial assumed formation pressure, roughly 85 percent of the original in-place gas hydrate must have been produced, and the borehole annular space could hold no more than roughly 15 percent of the gas evolved from the dissociated gas hydrate. It is acknowledged that the borehole annular space would likely contain a significant volume of water, but for calculation purposes, the presence of water in the borehole annular space would result in even higher gas recovery ratios. In this assessment, a gas hydrate recovery ratio of 85 percent (assuming a well-abandonment pressure 25 percent of hydrostatic) was used to convert the in-place gas volume estimates within each of the 3D seismic-inferred hydrate accumulations to a technically recoverable gas volume (table 3). It is important to emphasize that numerical gas hydrate production simulations (as reviewed by Anderson and others, 2011a, 2011b) also indicate relatively high gasrecovery ratios for producing gas hydrate accumulations.
Upon closer examination of the relative size (volume of technically recoverable gas) of the 3D seismic-inferred gas hydrate accumulations (table 3 ), it was determined that the accumulations as imaged in NPRA were generally larger than those in the MPU. Also, the seismic-imaged gas hydrate accumulations in NPRA were in reservoirs associated with the Tuluvak-Schrader Bluff-Prince Creek Formations Gas Hydrate $\mathrm{AU}$, whereas the MPU gas hydrate accumulations are limited to reservoirs within the Sagavanirktok Formation Gas Hydrate AU. Because of the apparent size difference between the gas hydrate accumulations in the Tuluvak-Schrader Bluff-Prince Creek and Sagavanirktok AUs, it was decided not to merge the accumulation sizes from the NPRA and MPU 3D seismic mapping effort and to use each set of accumulation sizes as independent analogs for inferred gas hydrate accumulations in various geologic settings throughout the Northern Alaska Gas Hydrate TPS. In figures $27 A-B$, the size (volume of technically recoverable gas) of the $3 \mathrm{D}$-imaged gas hydrate accumulations in the MPU and NPRA have been depicted 

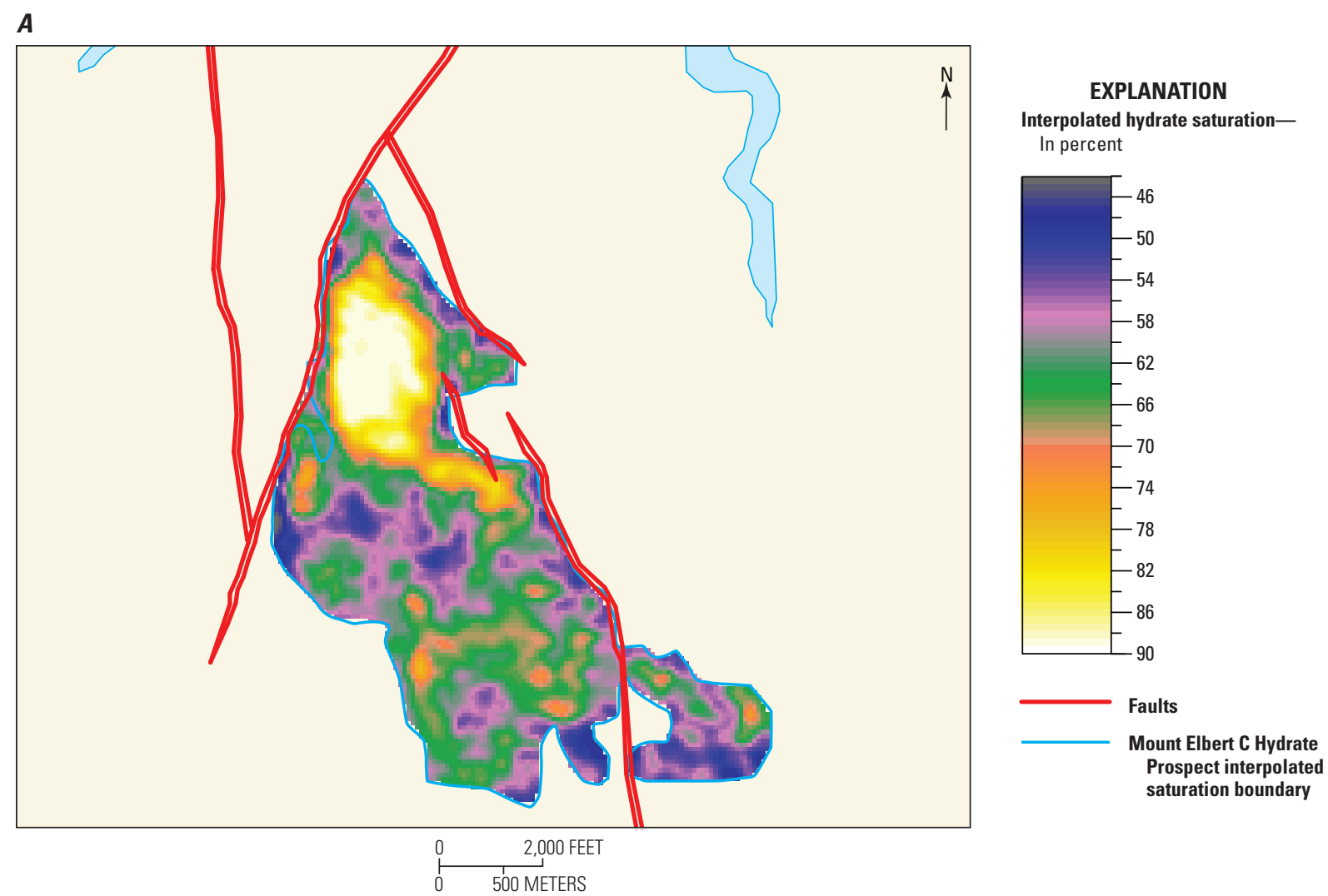

B
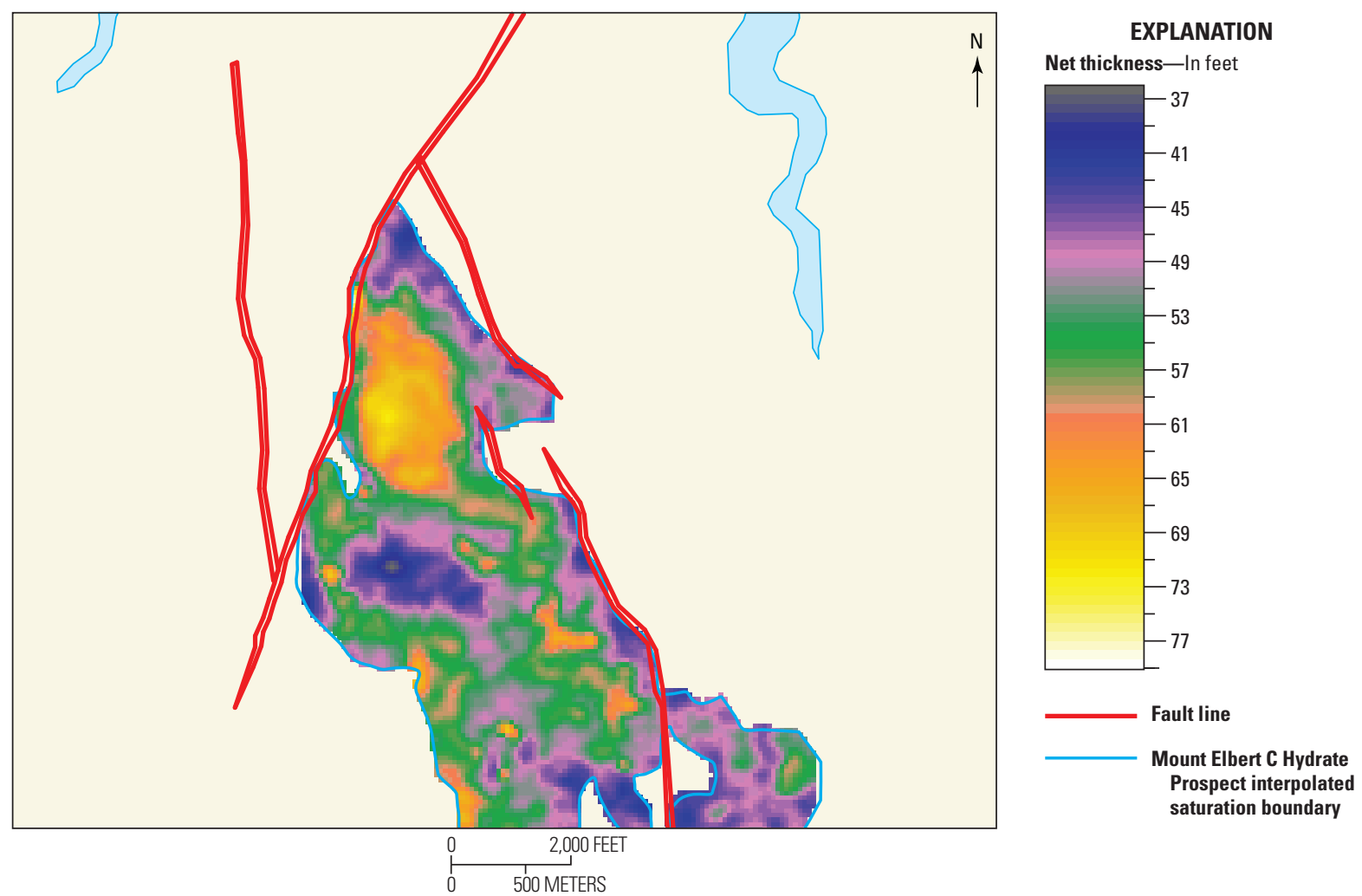

Figure 25. Maps showing pre-drill estimates of $A$, gas hydrate saturation, and $B$, reservoir thickness for hydrate unit $C$ in the Mount Elbert prospect. Modified from Inks and others (2009). As a condition of the seismic data use agreement, the latitude and longitude of the seismic data volume or the interpreted features cannot be shown on these maps. 


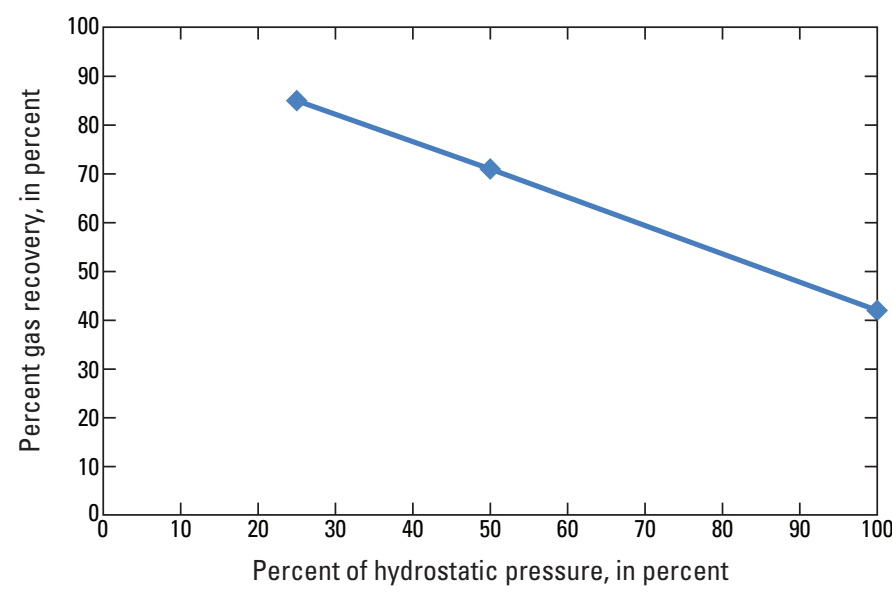

Figure 26. Gas hydrate recovery ratio (percent of in-place gas within gas hydrates that would be recovered) as a product of the producing well abandonment pressure (pressure is shown as a percent of hydrostatic pore pressure).

in two bar graphs. For the most part, the accumulation sizes shown in figures $27 A-B$ are characterized by log-normal distributions with increasing accumulation sizes to the right on the x-axes. However, analyses of well log and 2D seismic-inferred gas hydrate accumulations from outside the $3 \mathrm{D}$ seismic-imaged regions suggest that the accumulation sizes depicted in figures $27 A-B$ may not fully represent the complete range of potential gas hydrate accumulation sizes within the Northern Alaska Gas Hydrate TPS.

Detailed 2D seismic mapping and well-log studies south of the MPU in the Eileen trend of the PBU (fig. 23) indicate the occurrence of fault-bounded gas hydrate accumulations considerably larger than those mapped in the MPU, with one accumulation covering an area of roughly $11 \mathrm{mi}^{2}$. It appears the Sagavanirktok section in the MPU, which overlies the Barrow arch, is more highly faulted than the same reservoirs to the south into the PBU, thus leading to the variable accumulation sizes from north-to-south along the Eileen gas hydrate trend. To more accurately represent the full range of the potential gas hydrate-accumulation sizes in the Eileen trend, two hypothetical accumulations were added to the MPU 3D seismic-inferred distribution (fig. 28A), with the size of these two larger accumulations imported from the NPRA 3D seismic-inferred size distribution (table 3, fig. 27B).

It was also determined that the NPRA 3D seismicinferred accumulation size distribution (as depicted in figure 27B) did not accurately represent the full range of gas hydrate accumulation sizes likely to occur in NPRA. As discussed above, the ability of a given 3D seismic volume to image a potential gas hydrate accumulation is dependent on the frequency content of the available seismic data and the thickness and relative concentration of gas hydrate occurrences in the area being assessed. The frequency content of most of the NPRA 3D seismic volumes was considerably less than that of the MPU 3D volume used in this study; thus, it was assumed that some of the smaller gas hydrate accumulations in NPRA were not imaged. It was decided to augment the NPRA 3D seismic-inferred gas hydrate accumulation distribution with three relatively small hypothetical accumulations (fig. 28B) as imported from the MPU seismic inferred size distribution (table 3, fig. 27A).

The last critical step in the analysis of the "modified" MPU and NPRA 3D seismic-inferred gas hydrate accumulation size distributions (table 3, figs. $28 A-B$ ) was the selection of the minimum accumulation size to be considered in this assessment. Based mostly on the statistical nature of the two gas hydrate-size distributions, the minimum accumulation size was assumed to be 20 billion cubic feet (BCF) (3.33 Million Barrels of Oil Equivalent (MMBOE)) of technically recoverable gas. This minimum accumulation size is smaller than those used in other USGS assessments in northern Alaska, in recognition of the fact that most of the seismically inferred gas hydrate accumulations are in stacked reservoir sections and would likely be produced together from the same wells and production facilities.

The selection of the minimum, median, and maximum undiscovered accumulation sizes for each of the three gas hydrate AUs (as required within the USGS assessment methodology) is further discussed in the "Assessment-Data Form" section of this report.

\section{6.d. Undiscovered Gas Hydrate Accumulations- Number of Accumulations}

The next most critical component in the USGS assessment methodology is the accurate prediction of the number of undiscovered gas hydrate accumulations that may exist in the Northern Alaska Gas Hydrate TPS. It was again decided to rely on the MPU and NPRA 3D seismic analysis results to predict the possible number of gas hydrate accumulations in each of the AUs. As discussed earlier, the 3D seismic data volume from the MPU (figs. 9, 10, 24) covers an area of $155 \mathrm{mi}^{2}$, whereas the four 3D seismic volumes in NPRA cover an area of $729 \mathrm{mi}^{2}$. A total of nine gas hydrate accumulations (exceeding the minimum accumulation size for this assessment of $20 \mathrm{BCF}$ ) were identified within the coverage area of the MPU 3D seismic volume. Similarly, there were 10 gas hydrate accumulations (exceeding the minimum accumulation size for this assessment of $20 \mathrm{BCF}$ ) within the area covered by the four 3D seismic volumes in NPRA. In each case, the number of seismic-inferred gas hydrate accumulations relative to the area each survey covers was used to develop a "gas hydrate discovery ratio," which for the MPU 3D volume is 0.0581 gas hydrate accumulations for every square mile and for the NPRA 3D volumes is 0.0137 gas hydrate accumulations for every square mile. These "gas hydrate discovery ratios" were then used to estimate the number of gas hydrate accumulations (exceeding the minimum accumulation size) that may be within the areas of the North Slope without available 3D seismic coverage. 

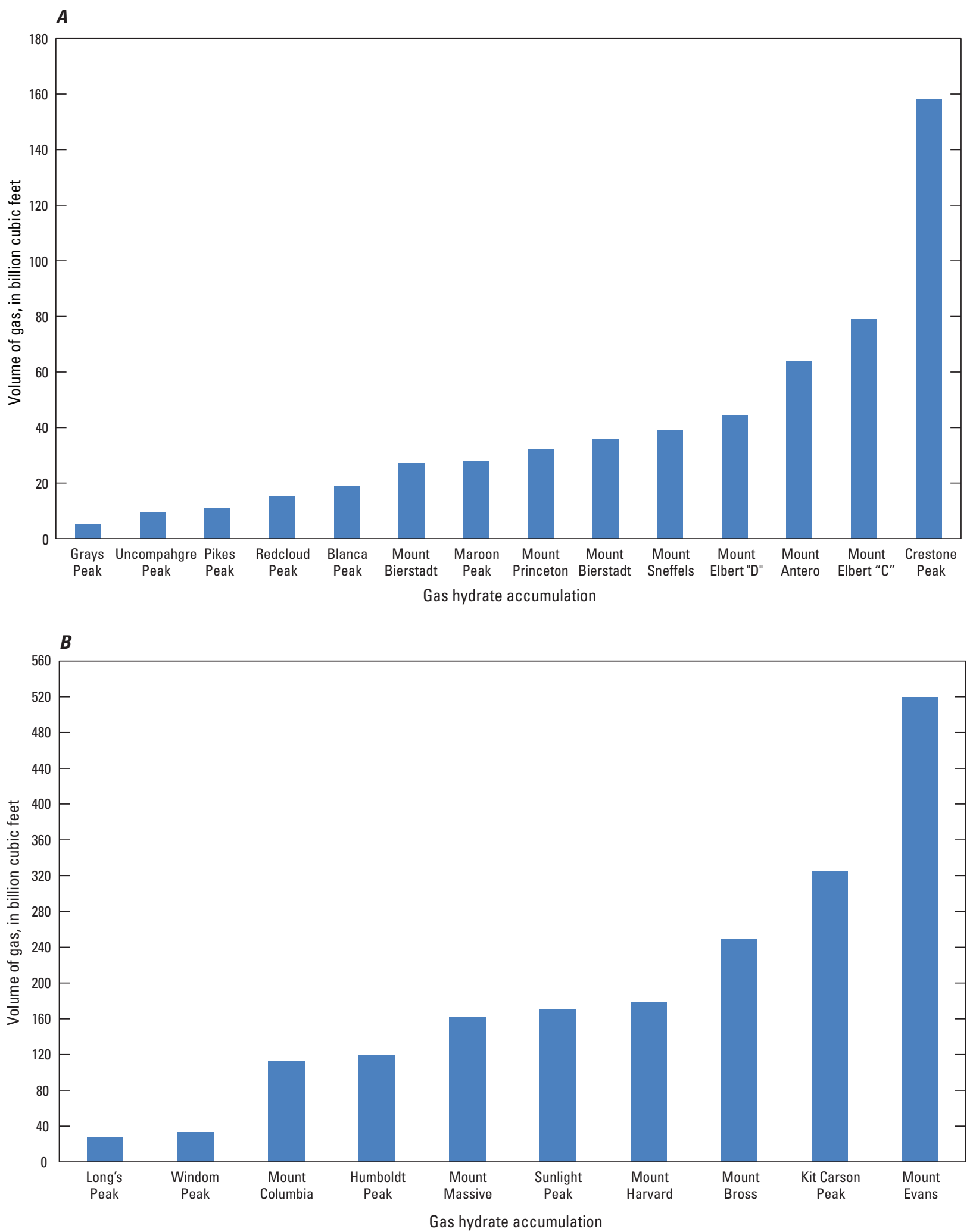

Figure 27. Bar-graph showing sizes of 3D-imaged gas hydrate accumulations in $A$, the Milne Point Unit (MPU, see fig. 10 for location) and $B$, the National Petroleum Reserve in Alaska (NPRA). Detailed data are given in table 3. 

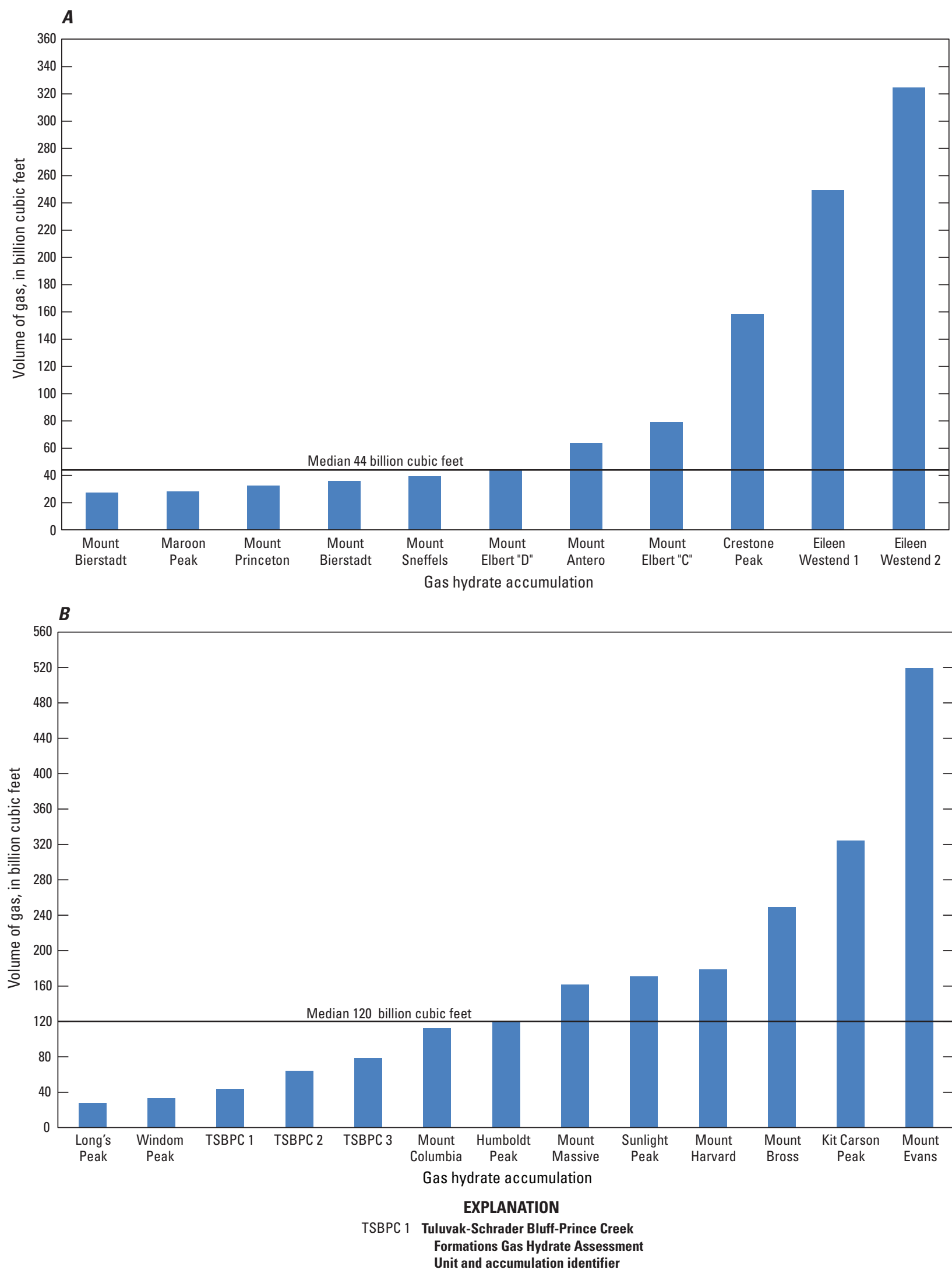

Figure 28. Bar-graph showing sizes of the 3D-imaged gas hydrate accumulations in $A$, the Milne Point Unit (MPU; see fig. 10 for location), and $B$, the National Petroleum Reserve in Alaska (NPRA), that have been modified to account for larger and smaller inferred gas hydrate accumulations in the MPU and NPRA, respectively. Also accumulations with sizes below the minimum accumulation size (20 BCF) have been deleted from these plots. 
Before attempting to use the MPU or NPRA 3D seismicderived "gas hydrate discovery ratios," it was recognized that these ratios are subject to uncertainty and are best represented as a probability distribution. For this assessment, the actual "gas hydrate discovery ratio" calculated from the MPU (0.0581 accumulations per square mile) and NPRA (0.0137 accumulations per square mile) prospecting efforts were set at the statistical mode; for the distribution around the mode, the maximum number of accumulations in each case was set at three times the value of the mode, and the minimum number of accumulations was set at the actual number of seismic identified gas hydrate accumulations in each of the AUs or was set at one in AUs with no 3D seismic inferred gas hydrate accumulations.

The next and final step in the assessment was to assign the appropriate "gas hydrate discovery ratio - distribution" (table 4) to each AU. However, the regional analysis of available 2D seismic and well-log data, along with geochemical analyses of well drill cuttings, core samples, and mud logs, indicates that the geologic controls on the occurrence of gas hydrate are not uniform throughout the defined AUs (Lorenson and others, 2011). As discussed in the "Gas Source and Migration" section of this report, most of the gas within the near-surface Eileen and Tarn gas hydrate accumulations had migrated from deeply buried thermogenic sources and is closely linked to the presence of conventional oil and gas fields. Thus, by considering the role of gas source and migration within the gas hydrate petroleum system, it is reasonable to assume that in areas with known conventional oil and gas accumulations and (or) in areas with evidence of an active petroleum system delivering thermogenic gas to the gas hydrate stability zone, there is an increased likelihood that these anomalous areas will contain significantly more gas hydrate accumulations.

To assess the potential contribution of thermogenic gas migration to the formation of gas hydrate accumulations on the North Slope, gas geochemistry data from 35 "wells-ofopportunity" (table 5, fig. 29; Lorenson and others, 2011; Lorenson and Collett, 2011) were examined. The "wells-ofopportunity," as described by Lorenson and Collett (2011), are mostly industry exploratory and development wells from which the USGS received drill cuttings and flowed gas samples in order to ascertain the composition and source of the gas within the inferred gas hydrate accumulations. For the wells listed in table 5 and highlighted on the map in figure 29 as wells with either significant or limited evidence of thermogenic gas in the gas hydrate stability zone, the area around these wells is more likely to contain a higher number of gas hydrate accumulations. The same is also true for the area around known conventional oil and gas fields (table 6). As discussed above, gas hydrate accumulations are commonly closely associated with more deeply buried conventional oil and gas fields that have leaked or possibly spilled gas that has migrated into the overlying gas hydrate stability zone, thus leading to a greater likelihood for the occurrence of gas hydrate.
Table 4. Determinations of "gas hydrate discovery ratiodistributions" resulting from the Milne Point Unit and the National Petroleum Reserve in Alaska 3D seismic gas hydrate prospecting effort.

\begin{tabular}{|c|c|}
\hline Milne Point Unit & $\begin{array}{c}\text { Number of accumulations } \\
\text { per square mile }\end{array}$ \\
\hline \multicolumn{2}{|c|}{ High probability } \\
\hline Minimum & 0.0111 \\
\hline Mode & 0.0581 \\
\hline Maximum & 0.1750 \\
\hline \multicolumn{2}{|c|}{ Middle probability } \\
\hline Minimum & 0.0056 \\
\hline Mode & 0.0278 \\
\hline Maximum & 0.0833 \\
\hline \multicolumn{2}{|c|}{ Low probability } \\
\hline Minimum & 0.0028 \\
\hline Mode & 0.0139 \\
\hline Maximum & 0.0417 \\
\hline $\begin{array}{c}\text { National Petroleum Reserve } \\
\text { in Alaska }\end{array}$ & $\begin{array}{c}\text { Number of accumulations } \\
\text { per square mile }\end{array}$ \\
\hline \multicolumn{2}{|c|}{ High probability } \\
\hline Minimum & 0.0056 \\
\hline Mode & 0.0137 \\
\hline Maximum & 0.0417 \\
\hline \multicolumn{2}{|c|}{ Middle probability } \\
\hline Minimum & 0.0028 \\
\hline Mode & 0.0083 \\
\hline Maximum & 0.0250 \\
\hline \multicolumn{2}{|c|}{ Low probability } \\
\hline Minimum & 0.0028 \\
\hline Mode & 0.0056 \\
\hline Maximum & 0.0167 \\
\hline
\end{tabular}

In order to assess the relative impact of thermogenic gas sources on the number of gas hydrate accumulations in each of the AUs, the "gas hydrate discovery ratiodistributions," as described above and listed in table 4, were expanded to include three options: (1) high probability, (2) middle probability, and (3) low probability. Within an area determined to have a high probability for the presence of thermogenic gas in the gas hydrate stability zone, the actual seismic-derived "gas hydrate discovery ratiodistribution" calculated from the available 3D surveys (table 4: mode of 0.0581 gas hydrate accumulations per square mile for the MPU and 0.0137 gas hydrate accumulations per square mile for NPRA) was assigned to this area. For an area with a middle probability for the presence of thermogenic gas in the gas hydrate stability zone, the actual seismic derived "gas hydrate discovery ratio-distribution" was reduced by 50 percent, which yielded a new middle probability mode of 0.0278 gas hydrate accumulations per square mile for the MPU distribution and 0.0083 gas hydrate accumulations per square mile for the NPRA distribution (table 4). For an area with a low probability for the presence of thermogenic gas in the gas hydrate stability zone, the actual seismic-derived "gas hydrate discovery ratiodistribution" was again reduced by another 50 percent, which yielded a new low probability mode of 0.0139 gas hydrate 
Table 5. List of wells of opportunity (see fig. 29) in which analyses of gas samples have been used to ascertain the composition and source of the gas within each of the gas hydrate assessment units in northern Alaska. Wells highlighted in blue are characterized by "significant" evidence for thermogenic gas in the mapped limits of the gas hydrate stability zone, whereas wells highlighted in green are assessed to have "limited" evidence of thermogenic gas in the gas hydrate stability zone. (API, American Petroleum Institute)

\begin{tabular}{|c|c|c|c|c|}
\hline Well API number & Operator current name & Well name & $\begin{array}{l}\text { Surface } \\
\text { latitude }\end{array}$ & $\begin{array}{c}\text { Surface } \\
\text { longitude }\end{array}$ \\
\hline \multicolumn{5}{|c|}{ Wells with significant evidence of thermogenic gas } \\
\hline 50029233020000 & BP EXPL ALASKA INC & MT. ELBERT 1 & 70.4556 & 149.4132 \\
\hline 50029232960000 & CONOCOPHILLIPS AK & KUPARUK RIVER UNIT WEST SAK 1H-SOUTH & 70.3949 & 149.5579 \\
\hline 50029210840000 & ARCO ALASKA INC & KUPARUK RIVER UNIT 2B-10 & 70.2894 & 149.9375 \\
\hline 50029211840000 & ARCO ALASKA INC & KUPARUK RIVER UNIT 2D-15 & 70.2840 & 149.7617 \\
\hline 50029216560000 & ARCO ALASKA INC & KUPARUK RIVER UNIT 3K-9 & 70.4332 & 149.7608 \\
\hline 50029219970000 & CONOCO INCORPORATED & MILNE POINT UNIT E-4 & 70.4554 & 149.4367 \\
\hline 50029203530000 & SOHIO PETROLEUM CO & PRUDHOE BAY UNIT R-1 & 70.3455 & 148.9108 \\
\hline 50029220470000 & BP EXPL ALASKA INC & PRUDHOE BAY UNIT S-26 & 70.3536 & 149.0302 \\
\hline 50029220460000 & BP EXPL ALASKA INC & PRUDHOE BAY UNIT Z-7 & 70.2977 & 149.1955 \\
\hline 50029217870000 & BP EXPL ALASKA INC & PRUDHOE BAY UNIT Z-8 & 70.2978 & 149.1996 \\
\hline 50103204800000 & CONOCOPHILLIPS AK & SPARK 4 & 70.2884 & 151.7924 \\
\hline 50103204790000 & CONOCOPHILLIPS AK & SCOUT 1 & 70.2867 & 151.9571 \\
\hline 50103205060000 & CONOCOPHILLIPS AK & IAPETUS 2 & 70.4079 & 151.1831 \\
\hline 50279200170000 & FEX LP & AMAGUQ 2 & 70.3932 & 155.8066 \\
\hline 50029232990000 & CONOCOPHILLIPS AK & ANTIGUA 1 & 70.1809 & 149.5267 \\
\hline 50279200110000 & CONOCOPHILLIPS AK & KOKODA 1 & 70.2850 & 153.1375 \\
\hline 50279200120000 & CONOCOPHILLIPS AK & KOKODA 5 & 70.3344 & 153.2046 \\
\hline 50103204810000 & CONOCOPHILLIPS AK & PLACER 1 & 70.3467 & 150.3983 \\
\hline \multicolumn{5}{|c|}{ Wells with limited evidence of thermogenic gas } \\
\hline 50279200180000 & FEX LP & AKLAQYAAQ 1 & 70.5573 & 155.4204 \\
\hline 50279200130000 & CONOCOPHILLIPS AK & NOATAK 1 & 70.3802 & 153.1335 \\
\hline 50301200030000 & U S DEPT OF INTER AK & WAINWRIGHT 1 & 70.6441 & 160.0237 \\
\hline 50103201900000 & EXXON CO USA & THETIS ISLAND 1 & 70.5539 & 150.1522 \\
\hline
\end{tabular}

accumulations per square mile for the MPU distribution and 0.0056 gas hydrate accumulations per square mile for the NPRA distribution (table 4).

The AU maps in figures 30,31 , and 32 depict the areas in each AU that exhibit low, middle, or high probability for the presence of thermogenic-derived gas hydrate accumulations. The Nanushuk Formation Gas Hydrate AU (fig. 30, table 7) was divided into four regions with two low probability and two middle probability map units; each area was assigned the appropriate NPRA "gas hydrate discovery ratio-distribution" as listed in table 4. The Tuluvak-Schrader Bluff-Prince Creek Formations Gas Hydrate AU (fig. 31, table 8) was divided into six regions with one low probability, three middle probability, and two high probability map units; each area was assigned the appropriate NPRA "gas hydrate discovery ratio-distribution" as listed in table 4. The Sagavanirktok Formation Gas Hydrate AU (fig. 32, table 9) was divided into five regions with one low probability, three middle probability, and one high probability map units; each area was assigned the appropriate MPU "gas hydrate discovery ratio-distribution" as listed in table 4.

The selection of the final minimum, mode, and maximum number of undiscovered gas hydrate accumulations, as required within the USGS assessment methodology, for each of the three gas hydrate AUs are further discussed in the "Assessment-Data Form" section of this report.

\section{Assessment-Data Form}

Information required for the assessment of the undiscovered gas hydrate resources on the Alaska North Slope, was entered on a form termed the Seventh Approximation Data Form for Conventional Assessment Units (Klett and others, 2005). The completed forms for each AU are reproduced in Appendixes A-1, A-2, and A-3. The assessment-data form contains six sections as described below. 


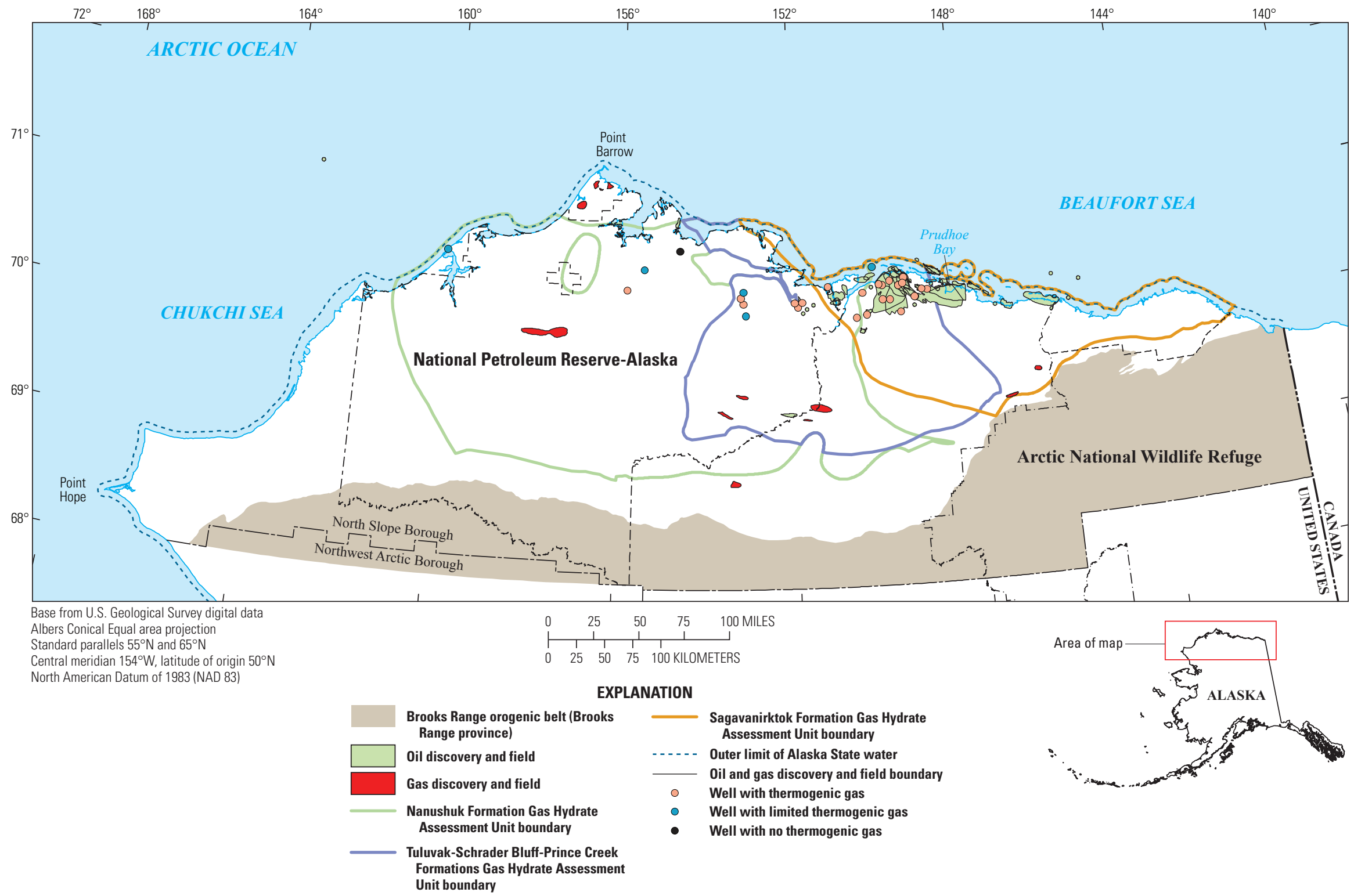

Figure 29. Map showing locations of the wells of opportunity (table 5) from which the analysis of gas samples were used to ascertain the composition and source of the gas within each of the gas hydrate assessment units in northern Alaska. Also shown are the locations of discovered conventional oil and gas fields (table 6). (NPRA, National Petroleum Reserve in Alaska; ANWR, Alaska National Wildlife Refuge) 


\section{7.a. Identification Information}

Identification information includes the assessors' names, the date of the assessment meeting at which input data were discussed and reviewed, and the names and numerical codes for each AU. Following a numbering system established by the USGS to facilitate petroleum resource assessments, the following unique numbers have been assigned to the Alaska North Slope gas hydrate TPS and AUs:

Northern Alaska Gas Hydrate TPS: 500102

Sagavanirktok Formation Gas Hydrate AU: 50010201

Tuluvak-Schrader Bluff-Prince Creek Formations Gas Hydrate AU: 50010202

Nanushuk Formation Gas Hydrate AU: 50010203

In this system " 5 " denotes the region (North America), "001" denotes the province (North Slope Alaska), and "02" denotes the TPS. The AUs are numbered as shown above with the last two digits denoting the specific AU.

\section{7.b. Characteristics of Assessment Unit}

This section of the form contains basic input data and information about the nature of the AU. In the first entry, the AU is classified as being either oil-prone or gas-prone. Because the assessment was for gas hydrates, it was assumed that all three AUs as defined contain only gas. The minimum accumulation size for all three AUs was set at 20 billion cubic feet (BCF) (3.33 MMBOE) of technically recoverable gas. Because none of the well-log- and (or) seismic-inferred gas hydrate accumulations on the North Slope have been produced, all of the AUs are considered hypothetical with no discovered accumulations exceeding the minimum gas hydrate accumulation size.

The assessment unit probability attributes for all three AUs were rated high, with a probability of 1.0 (or 100 percent) that there was at least one undiscovered gas hydrate accumulation greater than the minimum size existing in each AU. Ample evidence of gas hydrate occurrences in the Eileen and Tarn trends justifies the high ranking of the assessment unit probability for the Sagavanirktok Formation Gas Hydrate AU and the Tuluvak-Schrader Bluff-Prince Creek Formations Gas Hydrate AU. It can also be assumed that the Nanushuk Formation Gas Hydrate AU, being part of a prolific petroleum system, should have a high assessment unit probability ranking.

\section{7.c. Undiscovered Accumulations}

The third section of the data form is for recording the number and sizes of undiscovered oil and gas accumulations used to calculate the undiscovered resources that have potential for additions to reserves within the forecast span of 30 years. Minimum, median, and maximum values $\left(\mathrm{F}_{100}, \mathrm{~F}_{50}\right.$, and
Table 6. List of conventional oil and gas fields (see fig. 29) used in part to assign "gas hydrate discovery ratio-distributions" to various portions of the gas hydrate assessment units.

\begin{tabular}{lclc}
\hline \multicolumn{1}{c}{ Field } & $\begin{array}{c}\text { Field } \\
\text { type }\end{array}$ & \multicolumn{1}{c}{ Field } & $\begin{array}{c}\text { Field } \\
\text { type }\end{array}$ \\
\hline UMIAT & Oil & NORTHSTAR SADLEROCHIT & Oil \\
SOUTH BARROW & Gas & NORTHSTAR SAG RIVER & Oil \\
FISH CREEK & Oil & HEMI SPRINGS & Oil \\
MEADE & Gas & NIAKUK & Oil \\
SIMPSON & Oil & COLVILLE DELTA & Oil \\
WOLF CREEK & Gas & SANDPIPER & Oil \\
GUBIK & Gas & HAMMERHEAD & Oil \\
SQUARE LAKE & Gas & STUMP ISLAND & Oil \\
EAST UMIAT & Gas & POINT MCINTYRE & Oil \\
PRUDHOE BAY & Oil & SIKULIK & Gas \\
LISBURNE & Oil & BURGER & Oil \\
KUPARUK & Oil & BADAMI & Oil \\
SCHRADER BLUFF & Oil & STINSON & Oil \\
WEST SAK & Oil & TARN & Oil \\
UGNU & Oil & TABASCO & Oil \\
KUPARUK & Oil & FIORD & Oil \\
SAG RIVER & Oil & KALUBIK & Oil \\
AURORA & Oil & KUVLUM & Oil \\
KAVIK & Gas & CASCADE & Oil \\
GWYDYR BAY & Oil & THETIS ISLAND & \\
\hline
\end{tabular}

$\mathrm{F}_{0}$ fractals) are estimated for the sizes of the undiscovered accumulations. The number of undiscovered accumulations, however, is reported as minimum, mode, and maximum values.

As discussed in the "Undiscovered Gas Hydrate Accumulations-Number of Accumulations" section and shown in tables 7,8, and 9, the number of undiscovered gas hydrate accumulations has been derived from (1) the analysis of the petroleum system controlling the presence of gas hydrate in each AU and (2) the application of "gas hydrate discovery ratio - distributions" resulting from the analysis of the 3D seismic volumes in the MPU and NPRA. The actual values entered into the assessment-data form were slightly altered from the mathematically derived number of undiscovered gas hydrate accumulations as listed in tables 7, 8 , and 9 . This was done for the purpose of more accurately predicting the minimum number of undiscovered gas hydrate accumulations and of rounding the estimated number of accumulations to the nearest significant value.

As discussed in the "Undiscovered Gas Hydrate Accumulations - Sizes of Accumulations" section and shown in figures $28 A-B$, the sizes of the undiscovered gas hydrate accumulations in each of the AUs were determined by applying the two accumulation-size distributions developed in this study from the analysis of the 3D seismic volumes in the MPU and NPRA. In all three AUs, the minimum accumulation size was set at $20 \mathrm{BCF}$ (3.33 MMBOE). For the Sagavanirktok Formation Gas Hydrate AU, the MPU 3D seismic-derived accumulation size distribution as shown in figure $28 A$ was used to derive a median accumulation size of $45 \mathrm{BCF}$ (rounded up from the mathematically derived value of 44 BCF). The maximum size of the accumulations in the Sagavanirktok Formation Gas Hydrate AU was projected from 


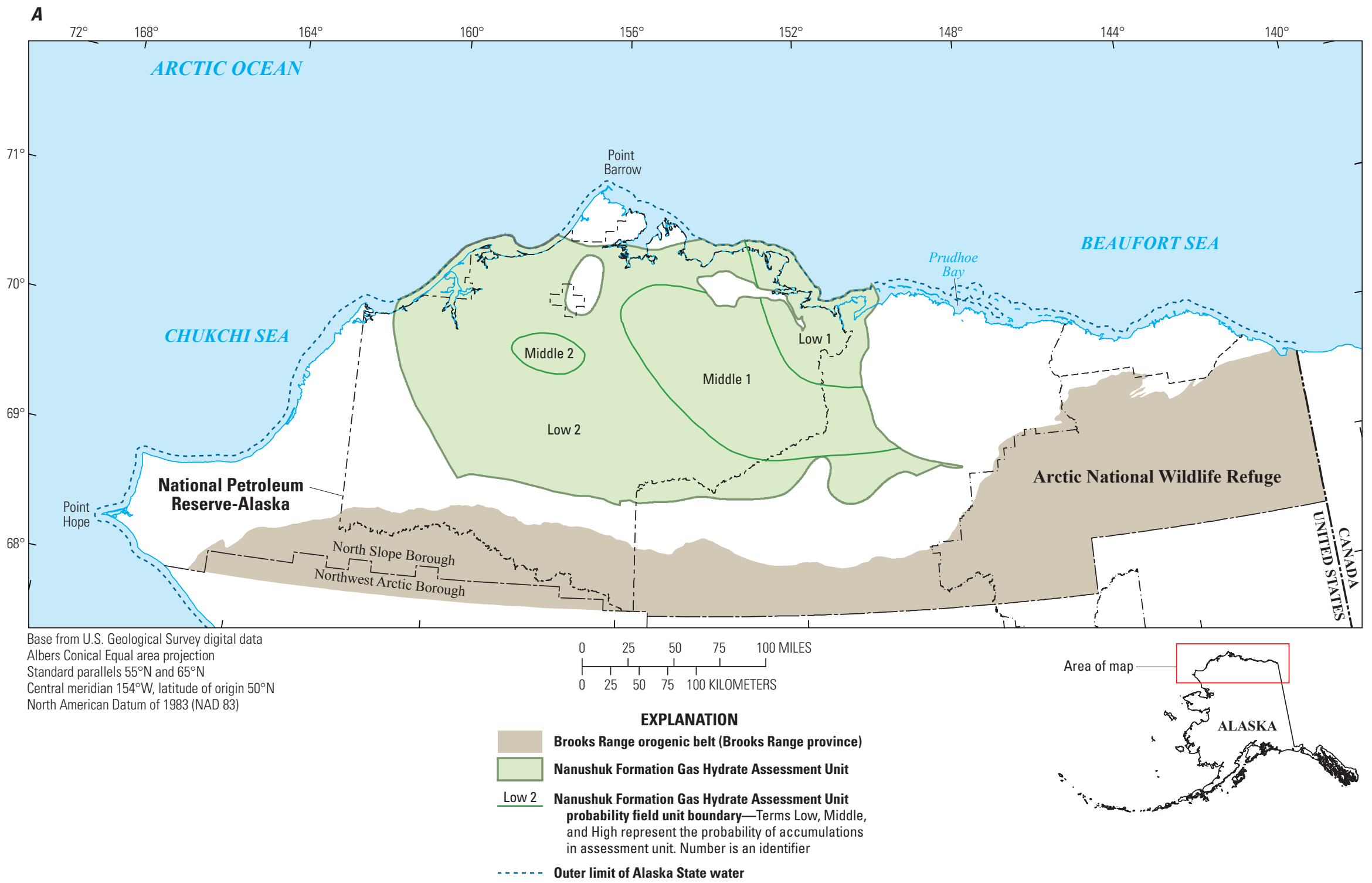

Figure 30. A, map of the Nanushuk Formation Gas Hydrate Assessment Unit showing areas outlined with high, middle or low "gas hydrate discovery ratio—distributions" (see table 7). $B$, same as $A$, but also includes locations of wells of opportunity and discovered oil and gas fields from figure 29. (NPRA, National Petroleum Reserve in Alaska; ANWR, Alaska National Wildlife Refuge) 


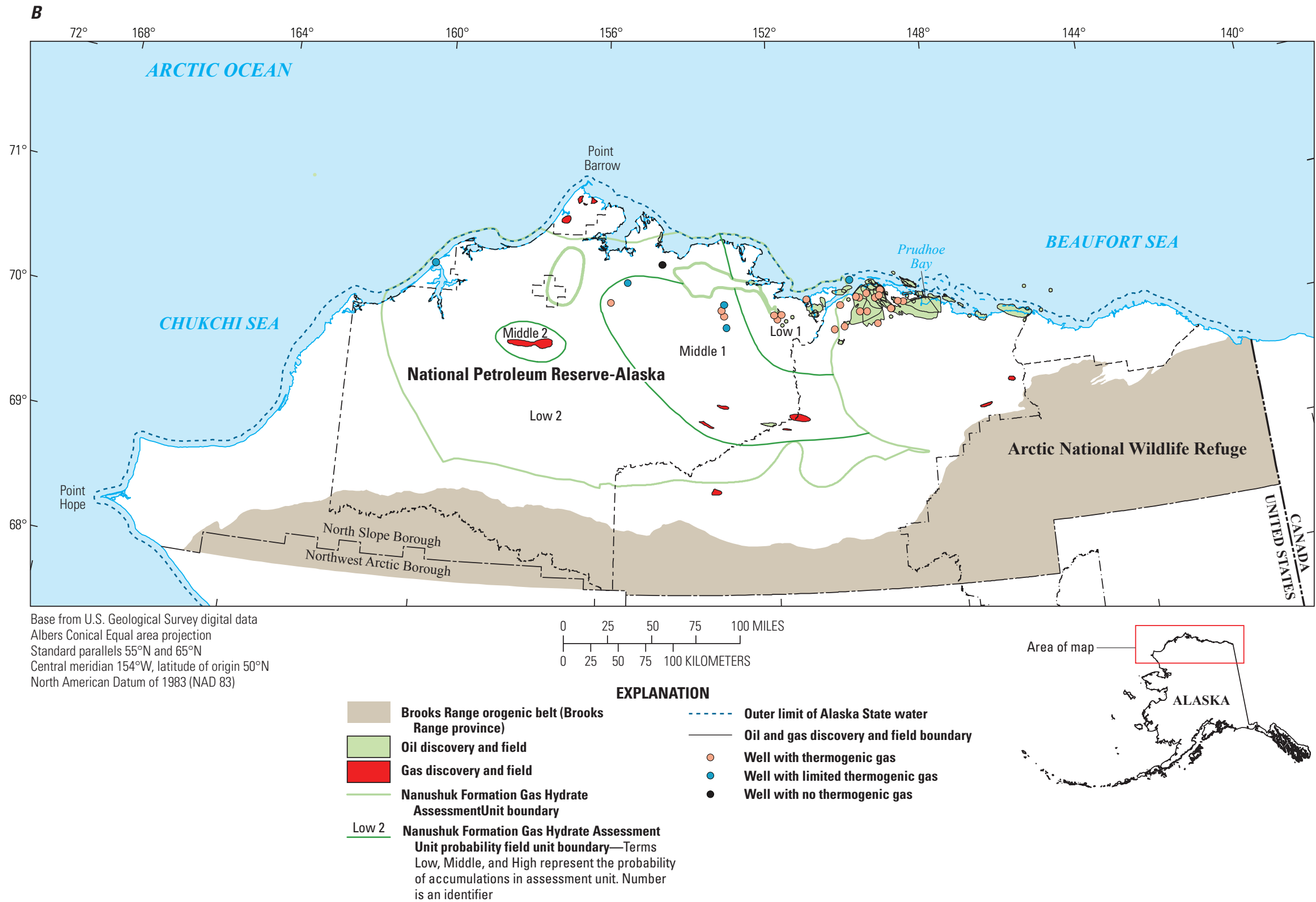

Figure 30. A, map of the Nanushuk Formation Gas Hydrate Assessment Unit showing areas outlined with high, middle or low "gas hydrate discovery ratio—distributions" (see table 7). $B$, same as $A$, but also includes locations of wells of opportunity and discovered oil and gas fields from figure 29. (NPRA, National Petroleum Reserve in Alaska; ANWR, Alaska National Wildlife Refuge)—Continued 
$\boldsymbol{A}$

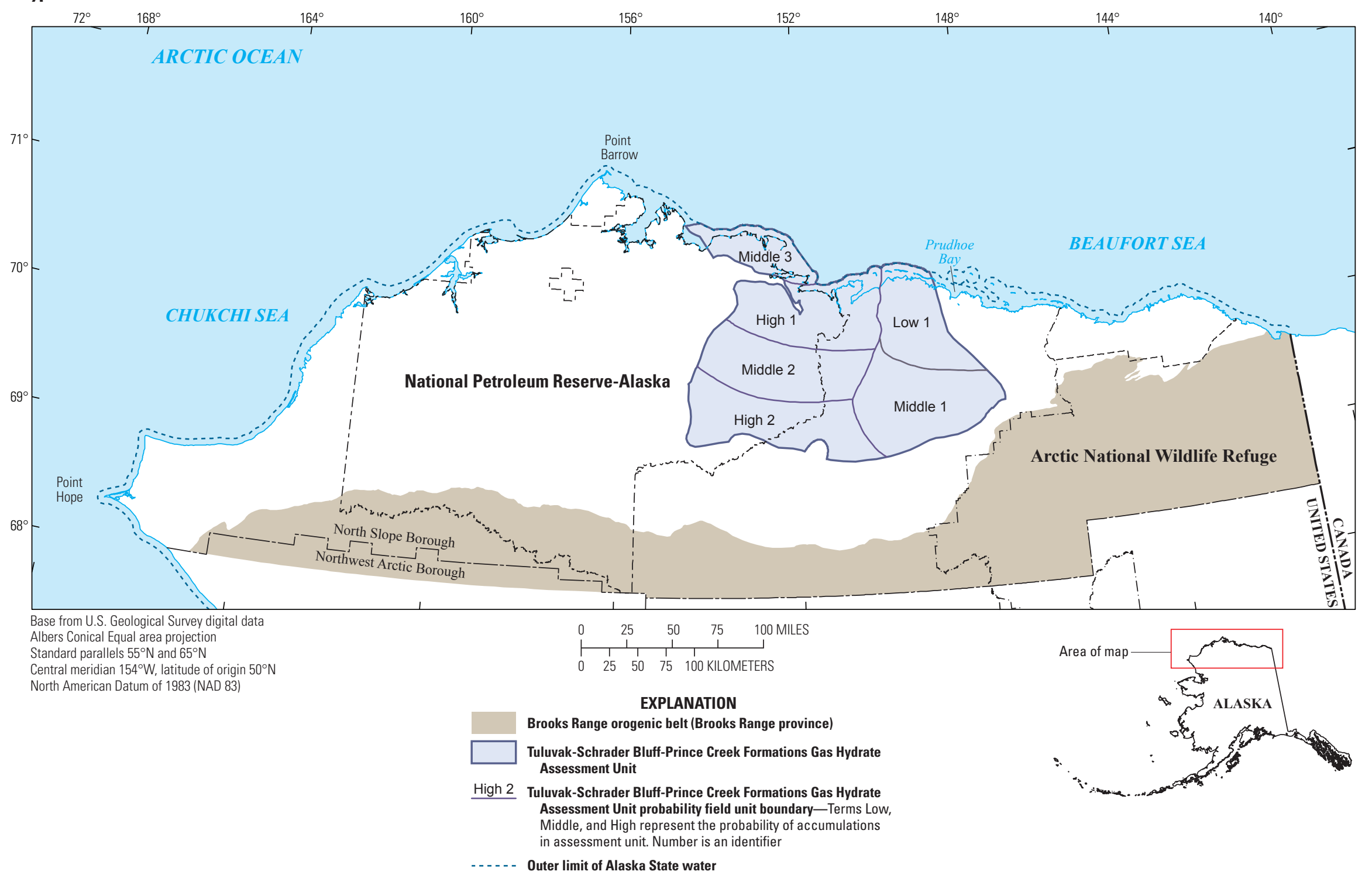

Figure 31. A, map of the Tuluvak-Schrader Bluff-Prince Creek Formations Gas Hydrate Assessment Unit showing areas outlined with high, middle or low "gas hydrate discovery ratio-distributions" (see table 8). $B$, same as $A$, but also includes locations of wells of opportunity and discovered oil and gas fields from figure 29. (NPRA, National Petroleum Reserve in Alaska; ANWR, Alaska National Wildlife Refuge) 


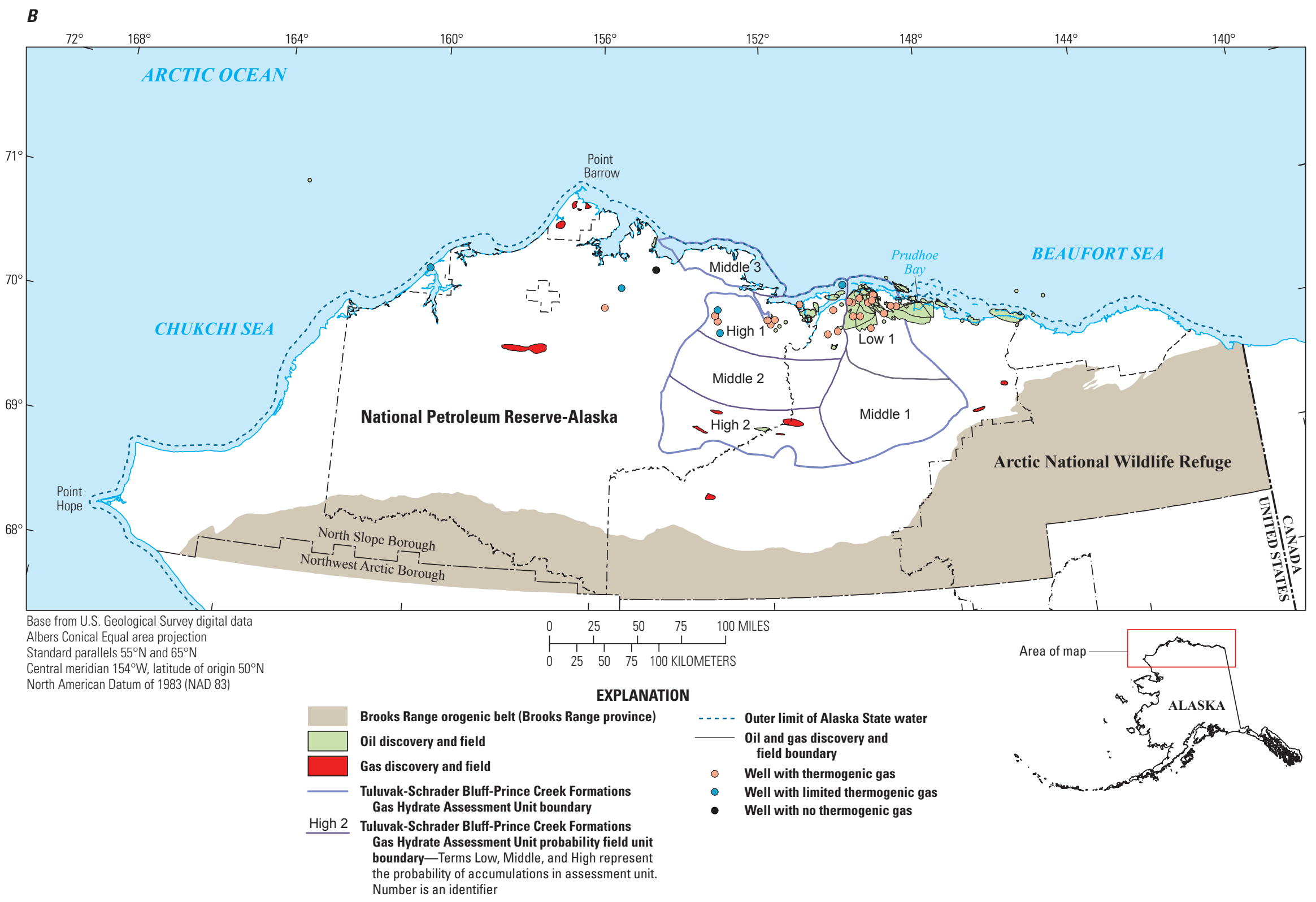

Figure 31. A, map of the Tuluvak-Schrader Bluff-Prince Creek Formations Gas Hydrate Assessment Unit showing areas outlined with high, middle or low "gas hydrate discovery ratio-distributions" (see table 8). $B$, same as $A$, but also includes locations of wells of opportunity and discovered oil and gas fields from figure 29. (NPRA, National Petroleum Reserve in Alaska; ANWR, Alaska National Wildlife Refuge)—Continued 
A

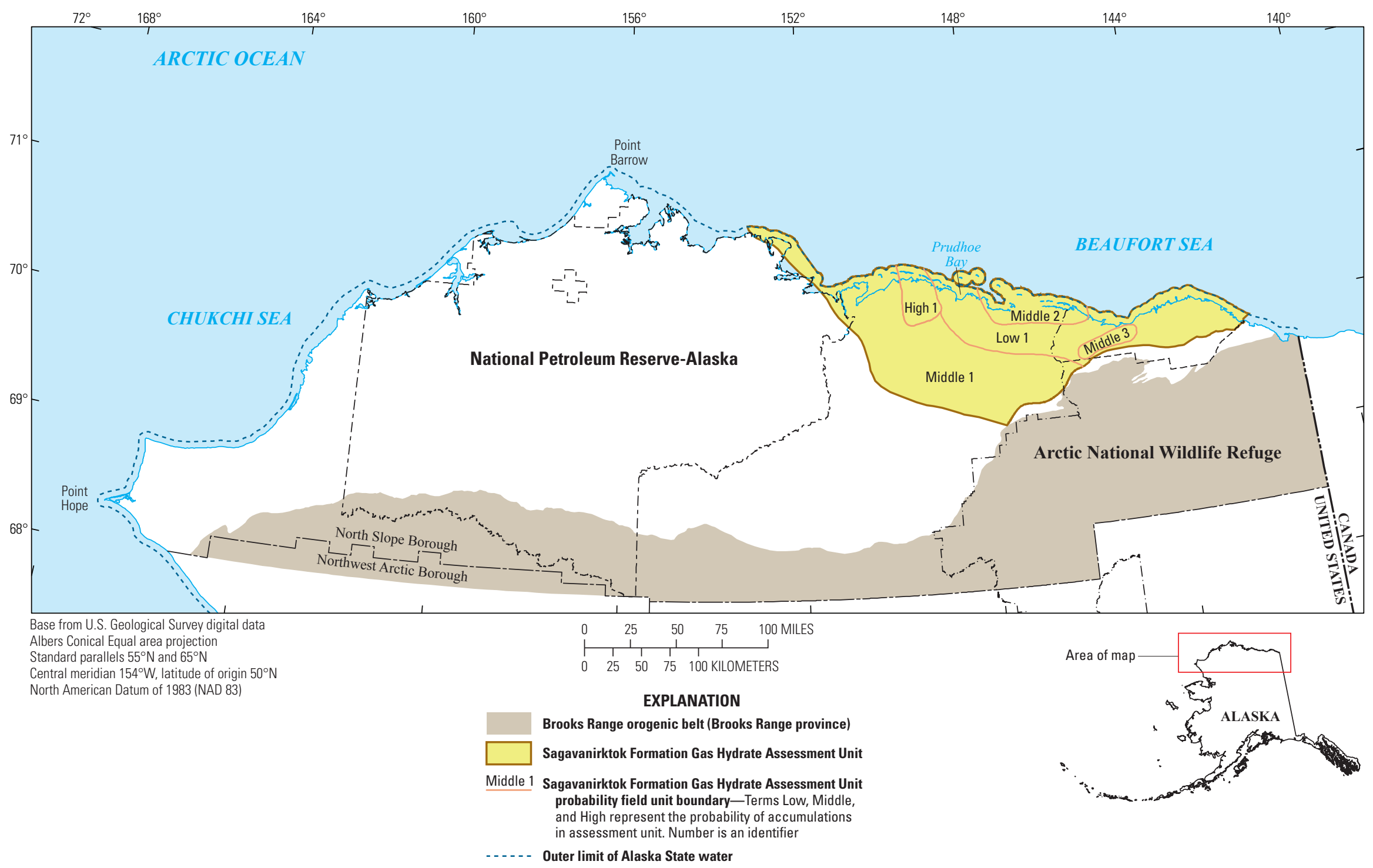

Figure 32. A, Map of the Sagavanirktok Formation Gas Hydrate Assessment Unit with the areas outlined with high, middle or low "gas hydrate discovery ratio—distributions" (table 9); $B$, with location of wells of opportunity and discovered oil and gas fields (fig. 29). (NPRA, National Petroleum Reserve in Alaska; ANWR, Alaska National Wildlife Refuge) 


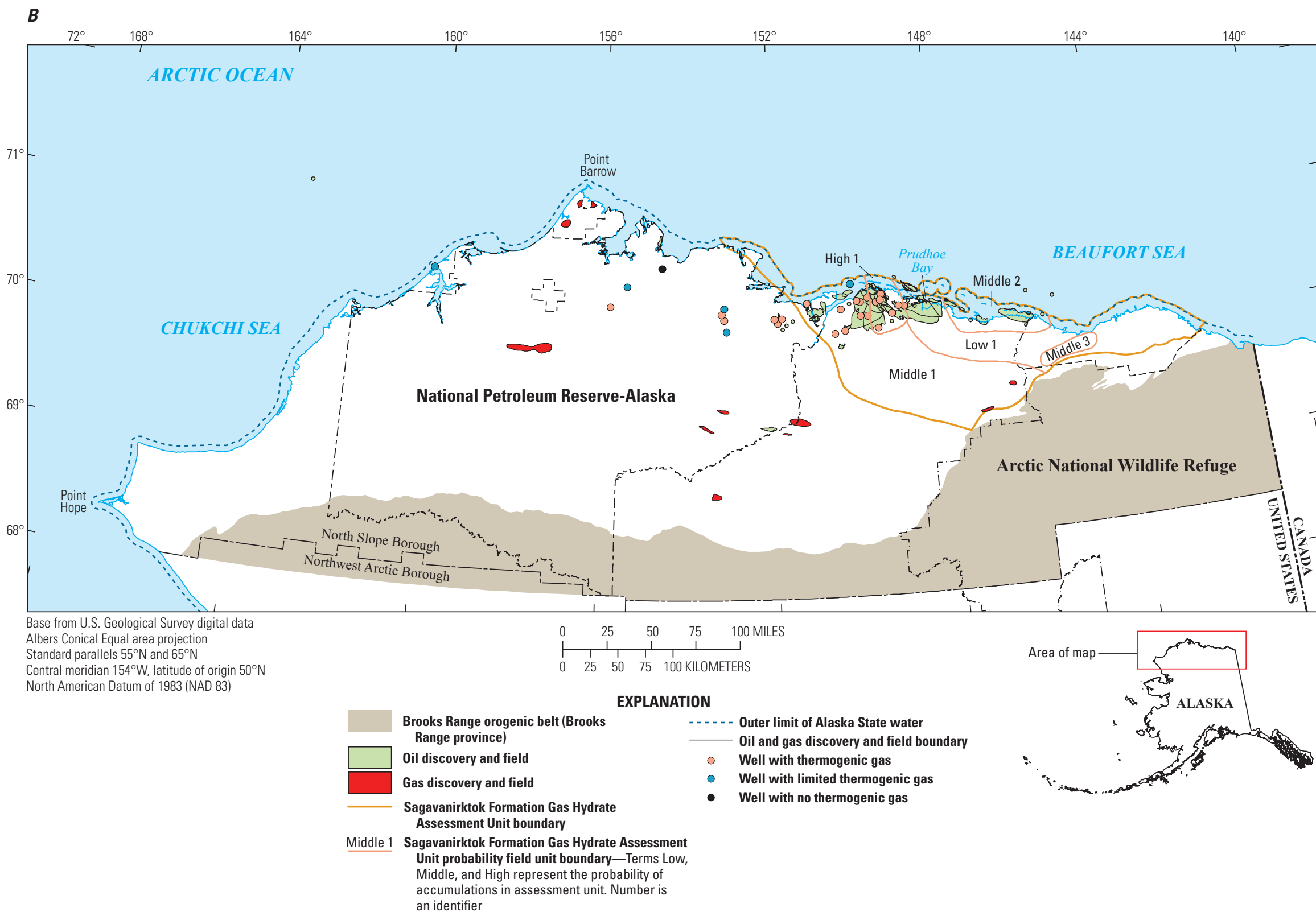

Figure 32. A, Map of the Sagavanirktok Formation Gas Hydrate Assessment Unit with the areas outlined with high, middle or low "gas hydrate discovery ratio—distributions" (table 9); $B$, with location of wells of opportunity and discovered oil and gas fields (fig. 29). (NPRA, National Petroleum Reserve in Alaska; ANWR, Alaska National Wildlife 
Table 7. Estimates of the number of undiscovered gas hydrate accumulations in the Nanushuk Formation Gas Hydrate Assessment Unit (see fig. 30).

$\left[\mathrm{mi}^{2}\right.$, square mile]

\begin{tabular}{|c|c|c|c|c|}
\hline \multirow{2}{*}{ Map unit } & \multirow{2}{*}{$\begin{array}{l}\text { Area } \\
\left(\mathrm{mi}^{2}\right)\end{array}$} & \multicolumn{3}{|c|}{ Number of gas hydrate accumulations } \\
\hline & & Minimum & Mode & Maximum \\
\hline Low 1 & 3,030 & 8 & 17 & 51 \\
\hline Low 2 & 19,675 & 55 & 109 & 328 \\
\hline Middle 1 & 7,617 & 21 & 63 & 190 \\
\hline Middle 2 & 641 & 2 & 5 & 16 \\
\hline Total - & 30,963 & 86 & 195 & 585 \\
\hline Used - & & 1 & 195 & 600 \\
\hline
\end{tabular}

Table 8. Estimates of the number of undiscovered gas hydrate accumulations in the Tuluvak-Schrader Bluff-Prince Creek Formations Gas Hydrate Assessment Unit (see fig. 31).

[mi² , square mile]

\begin{tabular}{|c|c|c|c|c|}
\hline \multirow{2}{*}{ Map unit } & \multirow{2}{*}{$\begin{array}{l}\text { Area } \\
\left(\mathrm{mi}^{2}\right)\end{array}$} & \multicolumn{3}{|c|}{ Number of gas hydrate accumulations } \\
\hline & & Minimum & Mode & Maximum \\
\hline Low 1 & 2,002 & 6 & 11 & 33 \\
\hline Middle 1 & 3,011 & 8 & 25 & 75 \\
\hline Middle 2 & 2,640 & 7 & 22 & 66 \\
\hline Middle 3 & 1,210 & 3 & 10 & 30 \\
\hline High 1 & 2,738 & 15 & 38 & 114 \\
\hline High 2 & 2,742 & 15 & 38 & 114 \\
\hline Total - & 14,343 & 55 & 143 & 433 \\
\hline Used - & & 1 & 145 & 450 \\
\hline
\end{tabular}

Table 9. Estimates of the number of undiscovered gas hydrate accumulations in the Sagavanirktok Formation Gas Hydrate Assessment Unit (see fig. 32).

[mi ${ }^{2}$, square mile]

\begin{tabular}{|c|c|c|c|c|}
\hline \multirow{2}{*}{ Map unit } & \multirow{2}{*}{$\begin{array}{l}\text { Area } \\
\left(\mathrm{mi}^{2}\right)\end{array}$} & \multicolumn{3}{|c|}{ Number of gas hydrate accumulations } \\
\hline & & Minimum & Mode & Maximum \\
\hline Low 1 & 3,510 & 10 & 49 & 146 \\
\hline Middle 1 & 5,361 & 30 & 149 & 447 \\
\hline Middle 2 & 910 & 5 & 25 & 76 \\
\hline Middle 3 & 253 & 1 & 7 & 21 \\
\hline High 1 & 554 & 6 & 32 & 97 \\
\hline Total - & 10,588 & 52 & 262 & 787 \\
\hline Used - & & 9 & 260 & 800 \\
\hline
\end{tabular}

the MPU accumulation size distribution at a value of $450 \mathrm{BCF}$. For the Tuluvak-Schrader Bluff-Prince Creek Formations Gas Hydrate AU and the Nanushuk Formation Gas Hydrate AU, the NPRA 3D seismic-derived accumulation size distribution as shown in figure $28 B$ was used to derive a median accumulation size of $120 \mathrm{BCF}$ for both AUs. The maximum size of the accumulations in the Tuluvak-Schrader BluffPrince Creek Formations Gas Hydrate AU and the Nanushuk Formation Gas Hydrate AU was also projected from the NPRA accumulation size distribution at a value of $675 \mathrm{BCF}$, but it was decided to increase the maximum accumulation size in the Tuluvak-Schrader Bluff-Prince Creek Formations Gas Hydrate AU to $700 \mathrm{BCF}$ to account for some of the apparent larger structures mapped in this AU.

\section{7.d. Assessment of Coproducts}

As described in the "Gas Hydrate Technical Review" section, in almost all cases, gas hydrates in nature contain mostly methane with only one reported case of a Structure $\mathrm{H}$ hydrate (recovered in a shallow core from an oil seep in the Gulf of Mexico) that was stabilized with a liquid range hydrocarbon. Thus, it was assumed that the undiscovered gas hydrate accumulations predicted in this assessment would not contain any natural gas liquids (that is, no coproducts).

\section{7.e. Selected Ancillary Data for Undiscovered Accumulations}

The data entered into this section of the form are useful for economic and environmental analyses of the assessment results, but do not contribute directly to the assessment calculations. Ancillary data as shown for each of the AUs include estimates of the inert-gas content (mostly nitrogen in this assessment), carbon dioxide content, hydrogen sulfide content, and estimated drilling and water depths.

\section{7.f. Allocations of Assessed Undiscovered Resources}

The resource allocation portion of the form includes input percentages necessary to allocate assessed undiscovered gas hydrate resources to various land entities of interest within each AU, as well as to the offshore portion of each entity. For this assessment, entities of interest include the State Lands (State of Alaska), the Federal Lands (Bureau of Land Management; U.S. Fish and Wildlife Service), Private Lands, Tribal Lands, a small category of Other Lands, and Alaska Offshore (State of Alaska). The estimated additions to reserves are also classified by the ecosystem in which they are likely to be found.

\section{Resource Assessment Results}

The USGS assessment strategy provides estimates of the volumes of undiscovered petroleum resources that are technically recoverable (table 10). For the Northern Alaska Gas Hydrate TPS, the USGS estimates that the total undiscovered natural gas resources in gas hydrate range between 25.2 and 157.8 trillion cubic feet (TCF; 95-percent and 5-percent probabilities of greater than these amounts, respectively), with a mean estimate of 85.4 TCF. Of this mean estimate, (1) about 24 percent (20.6 TCF) is in the Sagavanirktok Formation Gas Hydrate AU, (2) 33 percent (28.0 TCF) is within the Tuluvak-Schrader Bluff-Prince Creek Formations Gas Hydrate AU, and (3) 43 percent (36.9 TCF) is in the Nanushuk Formation Gas Hydrate AU (table 10). Given that relatively few wells have penetrated the expected gas hydrate accumulations in these three AUs, there is significant 
Table 10. Alaska North Slope—Gas hydrate assessment results. Results shown are fully risked estimates. F95 represents a 95-percent chance of at least the amount tabulated; other fractiles are defined similarly. Fractiles are additive, assuming perfect positive correlations.

[BCFG, billion cubic feet of gas. MMBNGL, million barrels of natural gas liquids; NGL, natural gas liquids; TPS, total petroleum system; AU, assessment unit]

\begin{tabular}{|c|c|c|c|c|c|c|c|c|c|}
\hline \multirow{2}{*}{$\begin{array}{l}\text { Total Petroleum System } \\
\text { and Assessment Unit }\end{array}$} & \multirow{2}{*}{$\begin{array}{l}\text { Field } \\
\text { type }\end{array}$} & \multicolumn{8}{|c|}{ Total undiscovered resources } \\
\hline & & \multicolumn{4}{|c|}{ Gas (BCFG) } & \multicolumn{4}{|c|}{ NGL (MMBNGL) } \\
\hline \multicolumn{10}{|c|}{ Northern Alaska Gas Hydrate TPS } \\
\hline $\begin{array}{l}\text { Tuluvak-Schrader Bluff-Prince Creek } \\
\text { Formations Gas Hydrate AU }\end{array}$ & Gas & 8,173 & 26,532 & 51,814 & 28,003 & 0 & 0 & 0 & 0 \\
\hline Nanushuk Formation Gas Hydrate AU & Gas & 10,775 & 35,008 & 68,226 & 36,857 & 0 & 0 & 0 & 0 \\
\hline
\end{tabular}

geologic uncertainty in these estimates that is reflected in the range of estimates in table 10. Of the estimated $85.4 \mathrm{TCF}$ of gas within hydrates on the North Slope, 56 percent is on federally managed lands, 39 percent on lands and offshore waters managed by the State of Alaska, and 4 percent on Native lands.

The mean estimate of $85.4 \mathrm{TCF}$ of gas within the gas hydrates of northern Alaska is considerably less than the 590 TCF reported in the 1995 USGS assessment (Collett, 1995). It is critical to note that the 1995 assessment only dealt with estimating the in-place volume of gas with hydrates, whereas this more recent assessment dealt only with technically recoverable gas. Also, the 1995 assessment included the offshore Federal waters (fig. $1 A-B$ ), which were not included in this assessment. In addition, the assessment results reported here are based on geologic data that were not previously available, which afforded a greatly improved appreciation of the North Slope gas hydrate petroleum system.

\section{References Cited}

Alaska Oil and Gas Conservation Commission, 1992, Summary of the Cirque-1 blowout of February 12, 1992: Anchorage, Alaska, public record letter from D.J. Ruckel, Atlantic Richfield Company (ARCO) Alaska, to D. Johnston, State of Alaska Oil and Gas Conservation Commissioner, 32 p.

Alaska Oil and Gas Conservation Commission, 2008, Digital well log files: Anchorage, Alaska, Alaska Oil and Gas Conservation Commission, Alaska Department of Administration, accessed April 12, 2008, at http://doa.alaska.gov/ogc/DigLog/diglogindex.html.

Anderson, B.J., Hancock, S.H., Wilson, S.J., Enger, C.S., Collett, T.S., Boswell, R.M., and Hunter, R.B., 2011a, Formation pressure testing at the Mount Elbert Gas Hydrate Stratigraphic Test Well, Alaska North Slope-Operational summary, history matching, and interpretations: Journal of Marine and Petroleum Geology, v. 28, no. 2, p. 478-492.
Anderson, B.J., Kurihara, M., White, M.D., Moridis, G.J., Wilson, S.J., Pooladi-Darvish, M., Gaddipati, M., Masuda, Y., Collett, T.S., Hunter, R.B., Narita, H., Rose, K., and Boswell, R., 2011b, Regional long-term production modeling from a single well test, Mount Elbert Gas Hydrate Stratigraphic Test Well, Alaska North Slope: Journal of Marine and Petroleum Geology, v. 28, no. 2, p. 493-501.

Anderson, B.J., Wilder, J.W., Kurihara, M., White, M.D., Moridis, G.J., Wilson, S.J., Pooladi-Darvish, M., Masuda, Y., Collett, T.S., Hunter, R.B., Narita, H., Rose, K., and Boswell, R., 2008, Analysis of modular dynamic formation test results from the Mount Elbert 01 stratigraphic test well, Milne Point Unit, North Slope, Alaska, in International Conference on Gas Hydrates (ICGH 2008), 6th, Vancouver, British Columbia, Canada, 6-10 July 2008, Proceedings: International Conference on Gas Hydrates, $10 \mathrm{p}$.

ANWR Assessment Team, U.S. Geological Survey, 1999, The oil and gas resource potential of the Arctic National Wildlife Refuge 1002 Area, Alaska: U.S. Geological Survey OpenFile Report 98-34.

Archie, G.E., 1942, The electrical resistivity log as an aid in determining some reservoir characteristic: Journal of Petroleum Technology, v. 5, p. 1-8.

Bard, H.B., and Fairbanks, R.G., 1990, U-Th ages obtained by mass spectrometry in corals from Barbados, sea level during the past 130,000 years: Nature, v. 346, p. 456-458.

Bird, K.J., 1998, Geographic and geologic setting, chap GG of The oil and gas resource potential of the Arctic National Wildlife Refuge 1002 Area, Alaska, by ANWR Assessment Team: U.S. Geological Survey Open-File Report 98-34, Version 1.0, p. GG1-GG51, CD-ROM. (Also available at http://pubs.usgs.gov/of/1998/ofr-98-0034/GG.pdf.)

Bird, K.J., and Houseknecht, D.W., 2002, U.S. Geological Survey 2002 petroleum resource assessment of the National Petroleum Reserve in Alaska (NPRA) - Play maps and technically recoverable resource estimates: U.S. Geological Survey, Open-File Report 02-207. 
Bird, K.J., and Magoon, L.B., 1987, Petroleum geology of the northern part of the Arctic National Wildlife Refuge, Northeastern Alaska: U.S. Geological Survey Bulletin 1778, $324 \mathrm{p}$.

Boswell, R., Rose, K., Collett, T.S., Lee, M.W., Winters, W.F., Lewis, K., and Agena, W.F., 2011, Geologic controls on gas hydrate occurrence in the Mount Elbert prospect, Alaska North Slope, in Boswell, R., Collett, T., Anderson, B., and Hunter, R., eds., Scientific results of the Mount Elbert gas hydrate stratigraphic test well, Alaska North Slope: Journal of Marine and Petroleum Geology, v. 28, no. 2, p. 589-607.

Carman, G.J., and Hardwick, Peter, 1983, Geology and regional setting of the Kuparuk oil field, Alaska: American Association of Petroleum Geologists Bulletin, v. 67, no. 6, p. 1014-1031.

Chapman, R.M., Detterman, R.L., and Mangus, M.D., 1964, Geology of the Killik-Etivuluk Rivers region, Alaska: U.S. Geological Survey Professional Paper 303-F, p. 325-407.

Collett, T.S., 1993, Natural gas hydrates of the Prudhoe Bay and Kuparuk River area, North Slope, Alaska: American Association of Petroleum Geologists Bulletin, v. 77, no. 5, p. 793-812.

Collett, T.S., 1995, Gas hydrate resources of the United States, in Gautier, D.L., Dolton, G.L., Takahashi, K.I., and Varnes, K.L., eds., 1995 National assessment of United States oil and gas resources on CD-ROM: U.S. Geological Survey Digital Data Series 30.

Collett, T.S., 2002, Energy resource potential of natural gas hydrates: American Association of Petroleum Geologists, v. 86 , no. 11, p. 1971-1992.

Collett, T.S., Agena, W.F., Lee, M.W., Zyrianova, M.V., Bird, K.J., Charpentier, T.C., Houseknecht, D.W., Klett, T.R., Pollastro, R.M., and Schenk, C.J., 2008a, Assessment of gas hydrate resources on the North Slope, Alaska, 2008: U.S. Geological Survey Fact Sheet 2008-3073, 4 p. (Also available at $h t t p: / / p u b s . u s g s . g o v / f s / 2008 / 3073 /$.)

Collett, T.S., Bird, K.J., Kvenvolden, K.A., and Magoon, L.B., 1988, Geologic interrelations relative to gas hydrates within the North Slope of Alaska: U.S. Geological Survey OpenFile Report 88-389, 150 p.

Collett, T.S., and Dallimore, S.R., 2002, Detailed analysis of gas hydrate induced drilling and production hazards, in International Conference on Gas Hydrates, 4th, Yokohama, Japan, 19-23 May 2002, Proceedings: International Conference on Gas Hydrates, p. 47-52.
Collett, T.S., and Ginsburg, G.D., 1998, Gas hydrates in the Messoyakha gas field of the West Siberian BasinA re-examination of the geologic evidence: International Journal of Offshore and Polar Engineering, v. 8, no. 1, p. 22-29.

Collett, T.S., Johnson, A., Knapp, C., and Boswell, R., 2009, Natural gas hydrates-A review, in Collett, T., Johnson, A., Knapp, C., and Boswell, R., eds, Natural gas hydratesEnergy resource potential and associated geologic hazards: American Association of Petroleum Geologists Memoir, v. $89,74 \mathrm{p}$.

Collett, T.S., Riedel, M., Cochran, J.R., Boswell, R., Kumar, P., Sathe, A.V., and the NGHP Expedition 01 Scientific Party, 2008b, Indian continental margin gas hydrate prospects - Results of the Indian National Gas Hydrate Program (NGHP) Expedition 01: Proceedings of the 6th International Conference on Gas Hydrates (ICGH 2008), $6^{\text {th }}$, Vancouver, British Columbia, Canada, 6-10 July 2008, Proceedings: International Conference on Gas Hydrates, 10 p., accessed July 20, 2008, at http://hdl.handle.net/2429/1035

Dallimore, S.R., and Collett, T.S., Editors, 2005, Scientific results from the Mallik 2002 gas hydrate production research well program, Mackenzie Delta, Northwest Territories, Canada: Geological Survey of Canada Bulletin 585, 140 p. [Two CD-ROM set.]

Dallimore, S.R., Wright, J.F., Nixon, F.M., Kurihara, M., Yamamoto, K., Fujii, T., Fujii, K., Numasawa, M., Yasuda, M., and Imasato, Y., 2008a, Geologic and porous media factors affecting the 2007 production response characteristics of the JOGMEC/NRCAN/AURORA Mallik gas hydrate production research well, in International Conference on Gas Hydrates (ICGH 2008), 6th, Vancoyver, British Columbia, Canada, 6-10 July 2008, Proceedings: International Conference on Gas Hydrates, $10 \mathrm{p}$.

Dallimore, S.R., Wright, J.F., and Yamamoto, K., 2008b, Appendix D-Update on Mallik, in Energy from gas hydrates-Assessing the opportunities and challenges for Canada: Ottawa, Canada, Council of Canadian Academies, p. 196-200, accessed August 21, 2008, at http://www.scienceadvice.ca/en/assessments/ completed/gas-hydrates.aspx

Decker, P.L., 2007, Brookian sequence stratigraphic correlations, Umiat Field to Milne Point Field, westcentral North Slope, Alaska: Alaska Division of Geological and Geophysical Surveys Preliminary Interpretive Report 2007-2, 19 p., 1 sheet.

Detterman, R.L., Reiser, H.N., Brosge, W.P., and Dutro, Jr., J.T., 1975, Post-Carboniferous stratigraphy, northeastern Alaska: U.S. Geological Survey Professional Paper 886, $46 \mathrm{p}$. 
Garrity, C.P., Houseknecht, D.W., Bird, K.J., Potter, C.J., Moore, T.E., Nelson, P.H., and Schenk, C.J., 2005, U.S. Geological Survey 2005 oil and gas resource assessment of the Central North Slope, Alaska-Play maps and results: U.S. Geological Survey Open-File Report 02-439.

Glenn, R.K., and Allen, W.W., 1991, Geology, reservoir engineering and methane hydrate potential of the Walakpa Gas Field, North Slope, Alaska, Final Project Technical Report: prepared for the U.S. Department of Energy, Grant Number DEFG21-91MX28131, 26 p.

Grantz, Arthur, Holmes, M.L., and Kososki, B.A., 1975, Geologic framework of the Alaskan continental terrace in the Chukchi and Beaufort Seas, in Yorath, C.J., Parker, E.R., and Glass, D.J., eds., Canada's continental margins and offshore petroleum exploration: Canadian Society of Petroleum Geologists Memoir 4, p. 669-700.

Graue, A., Kvamme, B., Baldwin, B.A., Stevens, J., Howard, J., Ersland, G., Husebø, J., and Zornes, D.R., 2006, Magnetic resonance imaging of methane-Carbon dioxide hydrate reactions in sandstone pores: Society of Petroleum Engineers Annual Technical Conference and Exhibition, San Antonio, Tex., 24-27 September 2006, Proceedings: Society of Petroleum Engineers, Paper Number SPE 102915, $13 \mathrm{p}$.

Gryc, George, 1988, Geology and exploration of the National Petroleum Reserve in Alaska, 1974 to 1982: U.S. Geological Survey Professional Paper 1399, 940 p.

Gryc, George, Patton, W.W., Jr., and Payne, T.G., 1951, Present Cretaceous stratigraphic nomenclature of northern Alaska: Washington Academy of Sciences Journal, v. 41, no. 5 , p. $159-167$.

Hancock, S.H., Dallimore, S.R., Collett, T.S., Carle, D., Weatherill, B., Satoh, T., and Inoue, T., 2005, Overview of press-drawndown production-test results for the JAPEX/ JNOC/GSC et al., Mallik 5L-38 gas hydrate production research well, in Dallimore, S.R., and Collett, T.S., eds., Scientific Results from the Mallik 2002 Gas Hydrate Production Research Well Program, Mackenzie Delta, Northwest Territories, Canada: Geological Survey of Canada Bulletin 585. [Two CD-ROM set.]

Holder, G.D., Malone, R.D., and Lawson, W.F., 1987, Effects of gas composition and geothermal properties on the thickness and depth of natural-gas-hydrate zone: Journal of Petroleum Technology, September, p. 1147-1152.

Houseknecht, D.W., 2003, Brookian stratigraphic plays in the National Petroleum Reserve-Alaska (NPRA): U.S. Geological Survey Open-File Report 03-039, nonpaginated. (Also available online at http://pubs.usgs.gov/ of/2003/of03-039/.)
Hubbard, R.J., Edrich, S.P., and Rattey, R.P., 1987, Geologic evolution and hydrocarbon habitat of the "Arctic Alaska Microplate," in Tailleur, I., and Weimer, P., eds., Alaskan North Slope geology: Bakersfield, Calif., and Anchorage, Alaska, Pacific Section, Society of Economic Paleontologists and Mineralogists and Alaska Geological Society, p. 797-830.

Hunt, J.M., 1979, Petroleum geology and geochemistry: San Francisco, Calif., W.H. Freeman Publisher, 716 p.

Hunter, R.B., Collett, T.S., Boswell, R., Anderson, B.J., Digert, S.A., Pospisil, G., Baker, R., and Weeks, M., 2011, Mount Elbert gas hydrate stratigraphic test well, Alaska North Slope - Overview of scientific and technical program, in Boswell, R., Collett, T., Anderson, B., and Hunter, R., eds., Scientific results of the Mount Elbert gas hydrate stratigraphic test well, Alaska North Slope: Journal of Marine and Petroleum Geology, v. 28, no. 2, p. 295-310.

Inks, T.L., Lee, M.W., Agena, W.F., Taylor, D.J., Collett, T.S., Hunter, R.B., and Zyrianova, M.V., 2009, Seismic prospecting for gas hydrate and associated free-gas prospects in the Milne Point area of northern Alaska, in Collett, T., Johnson, A., Knapp, C., and Boswell, R., eds, Natural gas hydrates-Energy resource potential and associated geologic hazards: American Association of Petroleum Geologists Memoir 89, 18 p.

Klett, T.R., Schmoker, J.W., and Charpentier, R.R., 2005, U.S. Geological Survey input-data form and operational procedure for the assessment of conventional petroleum accumulations: U.S. Geological Survey Digital Data Series DDS-69-D, $10 \mathrm{p}$.

Kvenvolden, K.A., 1993, A primer in gas hydrates, in Howell, D.G., ed., The future of energy gases: U.S. Geological Survey Professional Paper 1570, p. 279-292.

Lachenbruch, A.H., Sass, J.H., Lawver, L.A., Brewer, M.C., Marshall, B.V., Munroe, R.J., Kennelly, J.P., Jr., Galanis, S.P., Jr., and Moses, T.H., Jr., 1987, Temperature and depth of permafrost on the Alaskan North Slope, in Tailleur, I.L., and Weimer, Paul, eds., Alaskan North Slope Geology: Bakersfield, Calif., Pacific Section, Society of Economic Paleontologists and Mineralogists and the Alaska Geological Society, Book 50, v. 2, p. 545-558.

Lee, M.W., Agena, W.F., Collett, T.S., and Inks, T.L., 2011, Pre- and post-drill comparison of the Mount Elbert gas hydrate prospect, Alaska North Slope, in Boswell, R., Collett, T., Anderson, B., and Hunter, R., eds., Scientific results of the Mount Elbert gas hydrate stratigraphic test well, Alaska North Slope: Journal of Marine and Petroleum Geology, v. 28, no. 2, p. 578-588. 
Lee, M.W., Collett, T.S., and Agena, W.F., 2008, Assessing gas-hydrate prospects on the North Slope of AlaskaTheoretical considerations: U.S. Geological Survey Scientific Investigations Report 2008-5175, 28 p.

Lee, M.W., Collett, T.S., and Inks, T.L., 2009, Seismic attribute analysis for gas-hydrate and free-gas prospects on the North Slope of Alaska, in Collett, T., Johnson, A., Knapp, C., Boswell, R., eds, Natural gas hydratesEnergy resource potential and associated geologic hazards: American Association of Petroleum Geologists Memoir 89, $14 \mathrm{p}$.

Lerand, M., 1973, Beaufort Sea, in McCrossan, R.G., ed., Future petroleum provinces of Canada-Their geology and potential: Canadian Society of Petroleum Geologists Memoir 1, p. 315-386.

Lewis, K.A., and Collett, T.S., 2013, Brookian sequence well $\log$ correlation sections and occurrence of gas hydrates, north central North Slope, Alaska: U.S. Geological Survey Scientific Investigations Report 2013-5050, 23 p., http://pubs.usgs.gov/sir/2013/5050.

Lorenson, T.D., and Collett, T.S., 2011, Gas hydrate prospecting using well cuttings and mud gas geochemistry from 35 wells, Alaska North Slope: U.S. Geological Survey Scientific Investigations Report 2011-5195, 27 p.

Lorenson, T.D., Collett, T.S., and Hunter, R.B., 2011, Gas geochemistry of the Mount Elbert Gas Hydrate Stratigraphic Test Well, Alaska North Slope-Implications for gas hydrate exploration in the Arctic, in Boswell, R., Collett, T., Anderson, B., and Hunter, R., eds., Scientific results of the Mount Elbert gas hydrate stratigraphic test well, Alaska North Slope: Journal of Marine and Petroleum Geology, v. 28, no. 2, p. 343-360.

Makogon, Y.F., 1981, Hydrates of natural gas: Tulsa, Okla., Okla., Penn Well Publishing Company, 237 p.

Makogon, Y.F., Trebin, F.A., Trofimuk, A.A., Tsarev, V.P., and Cherskiy, N.V., 1972, Detection of a pool of natural gas in a solid (hydrate gas) state: Doklady Academy of Sciences U.S.S.R., Earth Science Section, v. 196, p. 197-200.

Masterson, D., Dzou, L., Holba, A., Fincannon, A., and Ellis, L., 2001, Evidence for biodegradation and evaporative fractionation in West Sak, Kuparuk, and Prudhoe Bay field areas, North Slope, Alaska: Organic Geochemistry, v. 32, no. 3, p. 411-441.
Miller, J.J., Agena, W.F., Lee, M.W., Zihlman, F.N., Grow, J.A., Taylor, D.J., Killgore, Michele, and Oliver, H.L., 2000, Regional seismic lines reprocessed using post-stack processing techniques-National Petroleum Reserve, Alaska: U.S. Geological Survey Open-File Report 00-286. [1 CD-ROM disk]

Miller, J.J., Agena, W.F., Lee, M.W., Zihlman, F.N., Grow, J.A., Taylor, D.J., Killgore, Michele, and Oliver, H.L., 2001, Four regional seismic lines-National Petroleum Reserve, Alaska (supplement to U. S. Geological Survey Open-File Report 00-286): U.S. Geological Survey Open File Report Open-File Report 01-337. [1 CD-ROM disk]

Molenaar, C.M., 1983, Depositional relations of Cretaceous and lower Tertiary rocks, northeastern Alaska: American Association of Petroleum Geologists Bulletin, v. 67, no. 7, p. 1066-1080.

Molenaar, C.M., Bird, K.J., and Collett, T.S., 1987a, Regional correlation sections across the North Slope of Alaska: U.S. Geological Survey Miscellaneous Field Investigations Map, MF-1907, 1 plate.

Molenaar, C.M., Bird, K.J., and Kirk, A.R., 1987b, Cretaceous and Tertiary stratigraphy of northeastern Alaska, in Tailleur, I., and Weimer, P., eds., Alaskan North Slope Geology, v. 1: Bakersfield, California, Pacific Section, Society of Economic Paleontologists and Mineralogists and Alaska Geological Society, p. 513-528.

Molochushkin, E.N., 1978, The effect of thermal abrasion on the temperature of the permafrost in the coastal zone of the Laptev Sea, in International Conference on Permafrost, 2nd, Takutsk, USSR, 13-28 July 1973, Proceedings: Washington D.C., National Academy of Sciences, p. 90-93.

Moridis, G.J., Collett, T.S., Boswell, R., Kurihara, M., Reagan, M.T., Koh, C., and Sloan, E.D., 2009, Toward production from gas hydrates - Current status, assessment of resources, and simulation-based evaluation of technology and potential: Society of Petroleum Engineers Reservoir Evaluation and Engineering, v. 12, no. 5, p. 745-771.

Moridis, G.J., Collett, T.S., Pooladi-Darvish, M., Hancock, S., Santamarina, C., Boswell, R. Kneafsey, T., Rutqvist, J., Kowalsky, M., Reagan, M.T., Sloan, E.D., Sum, A.K., and Koh, C., 2011a, Challenges, uncertainties and issues facing gas production from gas hydrate deposits: Society of Petroleum Engineers Reservoir Evaluation and Engineering, v. 14 , no. 1, 76-112.

Moridis, G.J., Silpngarmlert, S., Reagan, M.T., Collett, T.S., and Zhang, K., 2011b, Gas production from a cold, stratigraphically bounded hydrate deposit at the Mount Elbert Site, North Slope, Alaska: Journal of Marine and Petroleum Geology, v. 28, no. 2, p. 517-534. 
Mull, C.G., Houseknecht, D.W., and Bird, K.J., 2003, Revised Cretaceous and Tertiary stratigraphic nomenclature in the Colville Basin, northern Alaska: U.S. Geological Survey Professional Paper 1673, $51 \mathrm{p}$.

Mull, C.G., Houseknecht, D.W., Pessel, G.H., and Garrity, C.P., 2006, Geologic map of the Umiat quadrangle, Alaska: U.S. Geological Survey Scientific Investigations Map 2817-D, scale 1:250,000.

Osterkamp, T.E., and Fei, T., 1993, Potential occurrence of permafrost and gas hydrates in the continental shelf near Lonely, Alaska: Proceedings of the Sixth International Conference on Permafrost, Beijing, China, July 5-9, 1993: Washington D.C., National Academy of Sciences, p. 500-505.

Park, Keun-Pil, Bahk, Jang-Jun, Kwon, Youngin, Kim, Gil-Young, Riedel, M., Holland, M., Schultheiss, P., Rose, K., and the UBGH-1 Scientific Party, 2008, Korean national program expedition confirm rich gas hydrate deposits in the Ulleung Basin, East Sea: Fire In the Ice Methane Hydrate Newsletter, Spring 2008, p. 6-9, accessed July 20, 2008, at http://www.netl.doe.gov/technologies/oil-gas/publications/ Hydrates/Newsletter/HMNewsSpring08.pdf\#page $=6$

Potter, C.J., and Moore, T.E., 2003, Brookian structural plays in the National Petroleum Reserve, Alaska: U.S. Geological Survey Open-File Report 03-266, 36 p. (Also available at http://pubs.usgs.gov/of/2003/of03-266/.)

Riedel, M., Collett, T.S., Malone, M.J., and the Expedition 311 Scientists, 2006, Proceedings of the Integrated Ocean Drilling Program: Prepared by the Ocean Drilling Program, Integrated Ocean Drilling Program, 311, Washington, D.C. (Integrated Ocean Drilling Program Management International, Inc.). doi:10.2204/iodp.proc.311.2006

Roberts, Stephen, 2008, Geologic assessment of undiscovered, technically recoverable coalbed-gas resources in Cretaceous and Tertiary Rocks, North Slope, and adjacent State waters, Alaska: U.S. Geological Survey Digital Data Series DDS-69-S.

Rose, K., Boswell, R., and Collett, T., 2011, Mount Elbert Gas Hydrate Stratigraphic Test Well, Alaska North Slope: Coring operations, core sedimentology, and lithostratigraphy, in Boswell, R., Collett, T., Anderson, B., and Hunter, R., eds., Scientific results of the Mount Elbert gas hydrate stratigraphic test well, Alaska North Slope: Journal of Marine and Petroleum Geology, v. 28, no. 2, p. 311-331.
Schmoker, J.W., and Charpentier, R.R., 2005, U.S. Geological Survey input-data form and operational procedure for assessment of conventional petroleum accumulations: U.S. Geological Survey Digital Data Series DDS-69-D, $10 \mathrm{p}$.

Schmoker, J.W., and Klett, T.R., 2005, U.S. Geological Survey assessment concepts for conventional petroleum accumulations: U.S. Geological Survey Digital Data Series DDS-69-D, 9 p.

Sloan, E.D., and Koh, C.A., 2008, Clathrate hydrates of natural gases (3d ed.): New York, New York, CRC Press, Taylor and Francis Group, 721 p.

Torres, M.E., Tréhu, A.M., Cespedes, N., Kastner, M., Wortmann, U.G., Kim, J.H., Long, P., Malinverno, A., Pohlman, J.W., Riedel, M., and Collett, T.S., 2008, Methane hydrate formation in turbidite sediments of northern Cascadia, IODP Expedition 311: Earth and Planetary Science Letters, v. 271, p. 170-180.

Walsh, T.P., Stokes, P.J., Singh, P. K., 2007, Characterization and quantification of the methane hydrate resource potential associated with the Barrow Gas Fields: Phase 1A Final Technical Report, DOE Project Number: DE-FC26-06NT42962, accessed November 5, 2007, at http://www.netl.doe.gov/technologies/oil-gas/publications/ Hydrates/reports/MH42962_FinalRptPhase1A.pdf

Werner, M.R., 1987, Tertiary and Upper Cretaceous heavy oil sands, Kuparuk River area, Alaskan North Slope, in Tailleur, I.L., and Weimer, Paul, eds., Alaskan North Slope Geology: Bakersfield, Calif., Pacific Section, Society of Economic Paleontologists and Mineralogists and the Alaska Geological Society, Book 50, v. 1, p. 109-118.

Yamamoto, K., and Dallimore, S., 2008, Aurora-JOGMECNRCan Mallik 2006-2008 Gas Hydrate Research Project progress: Fire in the Ice Methane Hydrate Newsletter, Summer 2008, p. 1-5, accessed August 1, 2008, at http://www.netl.doe.gov/technologies/oil-gas/publications/ Hydrates/Newsletter/HMNewsSummer08.pdf\#Page =1

Yang, S., Zhang, H., Wu, N., Su, X., Schultheiss, P., Holland, M., Zhang, G., Liang, J., Lu, J., and Rose, K., 2008, High concentration hydrate in disseminated forms obtained in Shenhu area, North Slope of South China Sea: International Conference on Gas Hydrates (ICGH 2008), 6th, 6-10 July 2008, Vancouver, British Columbia, Canada, Proceedings: International Conference on Gas Hydrates, $10 \mathrm{p}$. 



\section{Appendixes}

Appendix 1. Basic input data (Seventh data form) used in estimates of the numbers and sizes of undiscovered gas hydrate accumulations in the Sagavanirktok Formation Gas Hydrate Assessment Unit (50010201) in the Northern Alaska Gas Hydrate Total Petroleum System.

\section{SEVENTH APPROXIMATION \\ DATA FORM FOR CONVENTIONAL ASSESSMENT UNITS (Version 6, 9 April 2003)}

IDENTIFICATION INFORMATION

Assessment Geologist:

Region:

Province:

Total Petroleum System:

Assessment Unit:

Based on Data as of:

Notes from Assessor:
T.S. Collett, W.F. Agena, M.W. Lee, M.V. Zyrianova North America

Northern Alaska

Northern Alaska Gas Hydrate

Sagavanirktok Formation Gas Hydrate
Date: $\quad$ 4-Jun-08 Number: 5 Number: 5001 Number: Number:



\section{CHARACTERISTICS OF ASSESSMENT UNIT}

Oil (<20,000 cfg/bo overall) or Gas ( $\geq 20,000 \mathrm{cfg} / \mathrm{bo}$ overall): ․ Gas

What is the minimum accumulation size? $\quad 3.33$ mmboe grown

(the smallest accumulation that has potential to be added to reserves)

No. of discovered accumulations exceeding minimum size:

Established (>13 accums.)
Oil: $\frac{0}{\text { Hypothetical (no accums }}$

3rd 3rd 3rd 3rd

Median size (grown) of discovered oil accumulations ( $\mathrm{mmbo}$ ):

$$
\text { 1st 3rd }
$$

2nd 3rd

2nd 3rd

Assessment-Unit Probabilities:

Attribute

Probability of occurrence $(0-1.0)$

1. CHARGE: Adequate petroleum charge for an undiscovered accum. $\geq$ minimum size:

2. ROCKS: Adequate reservoirs, traps, and seals for an undiscovered accum. $\geq$ minimum size:

3. TIMING OF GEOLOGIC EVENTS: Favorable timing for an undiscovered accum. $\geq$ minimum siz

$\begin{array}{r}1.0 \\ \hline 1.0 \\ \hline 1.0 \\ \hline\end{array}$

Assessment-Unit GEOLOGIC Probability (Product of 1, 2, and 3):

1.0

\section{UNDISCOVERED ACCUMULATIONS}

No. of Undiscovered Accumulations: How many undiscovered accums. exist that are $\geq$ min. size?: (uncertainty of fixed but unknown values)

Oil Accumulations: Gas Accumulations:

$\begin{array}{ll}\operatorname{minimum}(>0) & 0 \\ \operatorname{minimum}(>0) & 9\end{array}$

mode mode 260 maximum
0 800

Sizes of Undiscovered Accumulations: What are the sizes (grown) of the above accums?:

(variations in the sizes of undiscovered accumulations)

Oil in Oil Accumulations (mmbo): Gas in Gas Accumulations (bcfg): minimum minimum median median maximum maximum 
Assessment Unit (name, no.)

Sagavanirktok Formation Gas Hydrate, 50010201

\section{AVERAGE RATIOS FOR UNDISCOVERED ACCUMS., TO ASSESS COPRODUCTS}

(uncertainty of fixed but unknown values)

Oil Accumulations:

minimum

mode

maximum

Gas/oil ratio (cfg/bo)

$\mathrm{NGL} / \mathrm{gas}$ ratio (bngl/mmcfg)

Gas Accumulations:

Liquids/gas ratio (bliq/mmcfg)

Oil/gas ratio (bo/mmcfg)
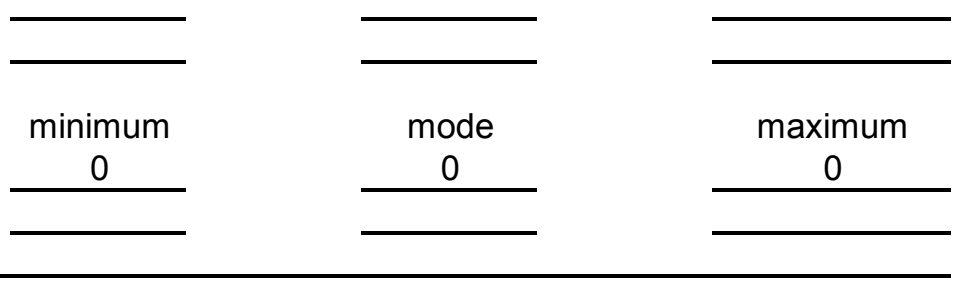

\section{SELECTED ANCILLARY DATA FOR UNDISCOVERED ACCUMULATIONS}

(variations in the properties of undiscovered accumulations)

Oil Accumulations:

minimum

API gravity (degrees)

Sulfur content of oil (\%)

Depth $(m)$ of water (if applicable)

Drilling Depth $(m)$

Gas Accumulations:

Inert gas content (\%)

$\mathrm{CO}_{2}$ content (\%)

Hydrogen-sulfide content (\%)

Depth ( $\mathrm{m}$ ) of water (if applicable)

Drilling Depth (m)
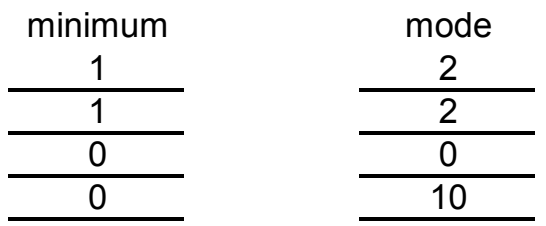

minimum

F75

mode

1200 maximum

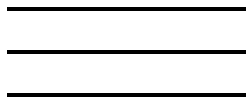

F25

maximum 
Assessment Unit (name, no.)

Sagavanirktok Formation Gas Hydrate, 50010201

\section{ALLOCATIONS OF POTENTIAL ADDITIONS TO RESERVES TO STATES \\ Surface Allocations (uncertainty of a fixed value)}

1. Alaska

Oil in Oil Accumulations:

Volume $\%$ in entity

Gas in Gas Accumulations:

Volume \% in entity

2.

Oil in Oil Accumulations:

Volume \% in entity

Gas in Gas Accumulations:

Volume \% in entity

3.

Oil in Oil Accumulations:

Volume \% in entity

Gas in Gas Accumulations:

Volume \% in entity

4.

Oil in Oil Accumulations:

Volume \% in entity

Gas in Gas Accumulations:

Volume \% in entity

5.

Oil in Oil Accumulations:

Volume \% in entity

Gas in Gas Accumulations:

Volume \% in entity

6.

Oil in Oil Accumulations:

Volume \% in entity

Gas in Gas Accumulations:

Volume \% in entity represents

100 area $\%$ of the $\mathrm{AU}$

minimum

mode

maximum

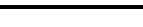

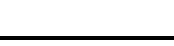
represents 100 area $\%$ of the $\mathrm{AU}$

minimum

mode

maximum

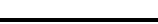

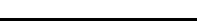
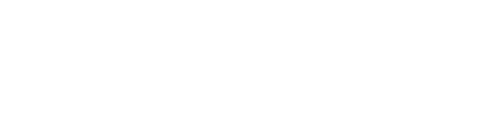

represents area $\%$ of the $\mathrm{AU}$

minimum

mode

maximum
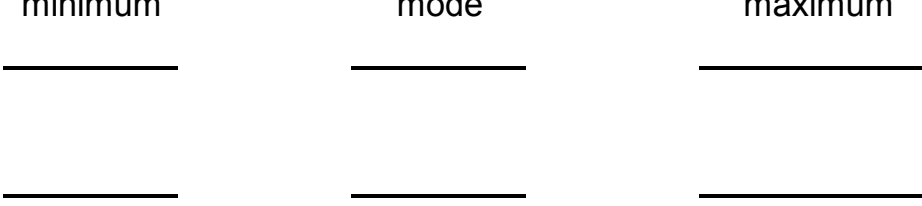

represents area $\%$ of the $\mathrm{AU}$

minimum

mode

maximum
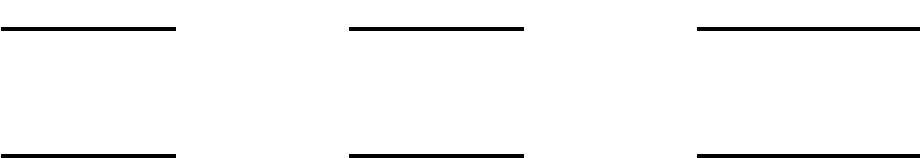

represents area $\%$ of the $\mathrm{AU}$

minimum

mode

maximum represents area $\%$ of the $\mathrm{AU}$

minimum

mode maximum 
Assessment Unit (name, no.)

Sagavanirktok Formation Gas Hydrate, 50010201

7.

Oil in Oil Accumulations:

Volume $\%$ in entity

Gas in Gas Accumulations:

Volume \% in entity

8.

Oil in Oil Accumulations:

Volume $\%$ in entity

Gas in Gas Accumulations:

Volume $\%$ in entity

9.

Oil in Oil Accumulations:

Volume $\%$ in entity

Gas in Gas Accumulations:

Volume $\%$ in entity

10.

Oil in Oil Accumulations:

Volume $\%$ in entity

Gas in Gas Accumulations:

Volume $\%$ in entity

11.

Oil in Oil Accumulations:

Volume $\%$ in entity

Gas in Gas Accumulations:

Volume $\%$ in entity

12.

Oil in Oil Accumulations:

Volume $\%$ in entity

Gas in Gas Accumulations:

Volume \% in entity represents area $\%$ of the $\mathrm{AU}$

mode

maximum

minimum

-
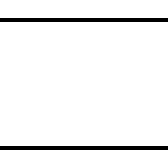

represents area $\%$ of the $\mathrm{AU}$

minimum

mode

maximum
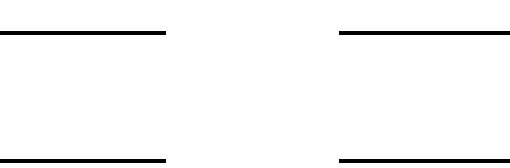
represents area $\%$ of the $\mathrm{AU}$

minimum

mode

maximum
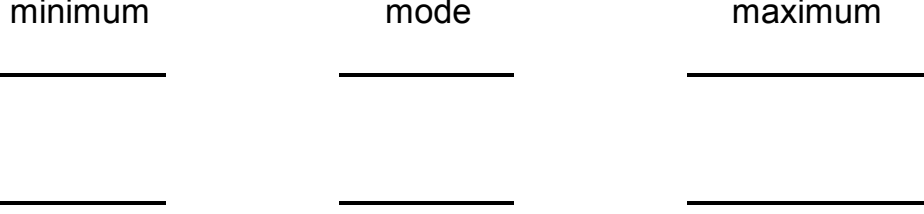

represents area $\%$ of the $\mathrm{AU}$

minimum

mode

maximum

represents area $\%$ of the $\mathrm{AU}$

minimum

mode

maximum represents area $\%$ of the $\mathrm{AU}$

minimum

mode maximum 
Assessment Unit (name, no.)

Sagavanirktok Formation Gas Hydrate, 50010201

\section{ALLOCATIONS OF POTENTIAL ADDITIONS TO RESERVES TO LAND ENTITIES \\ Surface Allocations (uncertainty of a fixed value)}

1. Federal Lands

Oil in Oil Accumulations:

Volume \% in entity

Gas in Gas Accumulations:

Volume $\%$ in entity

2. Private Lands

Oil in Oil Accumulations:

Volume \% in entity

Gas in Gas Accumulations:

Volume \% in entity

3. Tribal Lands

Oil in Oil Accumulations:

Volume $\%$ in entity

Gas in Gas Accumulations:

Volume $\%$ in entity

4. Other Lands

Oil in Oil Accumulations:

Volume \% in entity

Gas in Gas Accumulations:

Volume $\%$ in entity

5. AK State Lands

Oil in Oil Accumulations:

Volume \% in entity

Gas in Gas Accumulations:

Volume $\%$ in entity

6. AK Offshore

Oil in Oil Accumulations:

Volume \% in entity

Gas in Gas Accumulations:

Volume $\%$ in entity represents 18.03 area $\%$ of the AU

minimum

mode

maximum

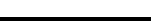

$\underline{-}$

10.00

represents

0.16

area $\%$ of the $\mathrm{AU}$

minimum

mode

maximum

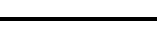

0.00

represents

3.04 area $\%$ of the $\mathrm{AU}$

mode

maximum

minimum

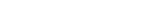

3.00

$\longrightarrow$ represents

1.44 area $\%$ of the $\mathrm{AU}$

minimum

mode

maximum

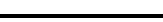

2.00

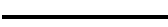

represents

59.14 area $\%$ of the $\mathrm{AU}$

minimum

mode

maximum
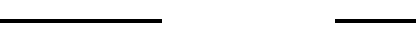

67.00

represents 18.19 area $\%$ of the $\mathrm{AU}$

minimum

mode

maximum 
Assessment Unit (name, no.)

Sagavanirktok Formation Gas Hydrate, 50010201

7. represents area $\%$ of the $\mathrm{AU}$

Oil in Oil Accumulations: Volume $\%$ in entity

minimum

mode

maximum

Gas in Gas Accumulations:

Volume \% in entity

8. represents area $\%$ of the $\mathrm{AU}$

Oil in Oil Accumulations:

minimum

mode

maximum

Volume $\%$ in entity

Gas in Gas Accumulations:

Volume $\%$ in entity

9. represents area $\%$ of the $\mathrm{AU}$

Oil in Oil Accumulations:

minimum

Volume $\%$ in entity

mode

maximum

Gas in Gas Accumulations:

Volume \% in entity

10. represents area $\%$ of the $\mathrm{AU}$

Oil in Oil Accumulations:

Volume $\%$ in entity

minimum

mode

maximum

Gas in Gas Accumulations:

Volume $\%$ in entity

11. represents area $\%$ of the $\mathrm{AU}$

Oil in Oil Accumulations:

minimum

mode

maximum

Volume \% in entity

Gas in Gas Accumulations:

Volume $\%$ in entity

12. represents area $\%$ of the $\mathrm{AU}$

Oil in Oil Accumulations:

minimum

mode maximum

Gas in Gas Accumulations:

Volume \% in entity 
Assessment Unit (name, no.)

Sagavanirktok Formation Gas Hydrate, 50010201

\section{ALLOCATIONS OF POTENTIAL ADDITIONS TO RESERVES TO FEDERAL LAND SUBDIVISIONS Surface Allocations (uncertainty of a fixed value)}

1. Bureau of Land Management (BLM) represents 0.97 area $\%$ of the $\mathrm{AU}$

Oil in Oil Accumulations: minimum mode maximum

Volume \% in entity

Gas in Gas Accumulations:

Volume \% in entity

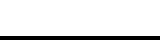

0.00

2. BLM Wilderness Areas (BLMW)

represents area $\%$ of the $\mathrm{AU}$

Oil in Oil Accumulations:

Volume $\%$ in entity

minimum

mode

maximum

Gas in Gas Accumulations:

Volume $\%$ in entity

3. BLM Roadless Areas (BLMR) represents area $\%$ of the $\mathrm{AU}$

Oil in Oil Accumulations:

minimum

Volume $\%$ in entity

Gas in Gas Accumulations:

Volume \% in entity

4. National Park Service (NPS)

represents area $\%$ of the $\mathrm{AU}$

Oil in Oil Accumulations:

minimum

mode

maximum

Volume \% in entity

Gas in Gas Accumulations:

Volume $\%$ in entity

5. NPS Wilderness Areas (NPSW)

represents area $\%$ of the $\mathrm{AU}$

Oil in Oil Accumulations:

minimum

mode

maximum

Volume \% in entity

Gas in Gas Accumulations:

Volume $\%$ in entity

6. NPS Protected Withdrawals (NPSP)

represents area $\%$ of the $\mathrm{AU}$

Oil in Oil Accumulations:

minimum

mode

maximum

Gas in Gas Accumulations:

Volume $\%$ in entity 
Assessment Unit (name, no.)

Sagavanirktok Formation Gas Hydrate, 50010201

7. US Forest Service (FS) represents area $\%$ of the $\mathrm{AU}$

Oil in Oil Accumulations:

minimum

mode

maximum

Volume \% in entity

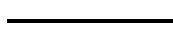

Gas in Gas Accumulations:

Volume $\%$ in entity

8. USFS Wilderness Areas (FSW)

represents area $\%$ of the $\mathrm{AU}$

Oil in Oil Accumulations:

minimum

maximum

Volume $\%$ in entity

Gas in Gas Accumulations:

Volume $\%$ in entity

9. USFS Roadless Areas (FSR)

represents

area $\%$ of the $\mathrm{AU}$

Oil in Oil Accumulations:

minimum

Volume $\%$ in entity

mode

maximum

Gas in Gas Accumulations:

Volume $\%$ in entity

10. USFS Protected Withdrawals (FSP)

represents area $\%$ of the $\mathrm{AU}$

Oil in Oil Accumulations:

minimum

Volume $\%$ in entity

mode

maximum

Gas in Gas Accumulations:

Volume $\%$ in entity

11. US Fish and Wildlife Service (FWS) represents

17.06 area $\%$ of the $\mathrm{AU}$

Oil in Oil Accumulations:

minimum

mode

maximum

Volume $\%$ in entity

Gas in Gas Accumulations:

Volume $\%$ in entity

10.00

12. USFWS Wilderness Areas (FWSW)

represents area $\%$ of the $\mathrm{AU}$

Oil in Oil Accumulations:

minimum

mode

maximum

Gas in Gas Accumulations:

Volume \% in entity 
Assessment Unit (name, no.)

Sagavanirktok Formation Gas Hydrate, 50010201

13. USFWS Protected Withdrawals (FWSP) represents area $\%$ of the $\mathrm{AU}$

Oil in Oil Accumulations:

minimum

mode

maximum

Volume $\%$ in entity

Gas in Gas Accumulations:

Volume \% in entity

14. Wilderness Study Areas (WS)

represents area $\%$ of the $\mathrm{AU}$

Oil in Oil Accumulations:

Volume $\%$ in entity

minimum

mode

maximum

Gas in Gas Accumulations:

Volume $\%$ in entity

15. Department of Energy (DOE) represents area $\%$ of the $\mathrm{AU}$

Oil in Oil Accumulations:

minimum

Volume $\%$ in entity

mode

maximum

Gas in Gas Accumulations:

Volume $\%$ in entity

16. Department of Defense (DOD) represents area $\%$ of the $\mathrm{AU}$

Oil in Oil Accumulations: Volume $\%$ in entity

minimum

mode

maximum

Gas in Gas Accumulations:

Volume \% in entity

17. Bureau of Reclamation (BOR) represents area $\%$ of the $\mathrm{AU}$

Oil in Oil Accumulations:

minimum

maximum

Volume \% in entity

Gas in Gas Accumulations:

Volume $\%$ in entity

18. Tennessee Valley Authority (TVA) represents area $\%$ of the $\mathrm{AU}$

Oil in Oil Accumulations:

minimum

mode maximum

Gas in Gas Accumulations:

Volume $\%$ in entity 
Assessment Unit (name, no.)

Sagavanirktok Formation Gas Hydrate, 50010201

19. Other Federal represents

area \% of the AU

Oil in Oil Accumulations:

Volume \% in entity

minimum

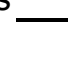

mode

Gas in Gas Accumulations:

Volume \% in entity

20.

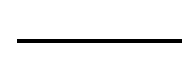

mode

maximum

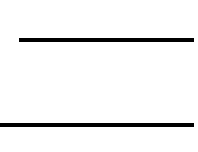

represents

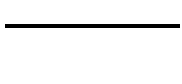

Oil in Oil Accumulations:

minimum

mode

area $\%$ of the $\mathrm{AU}$

Volume \% in entity

Gas in Gas Accumulations:

Volume $\%$ in entity 
Assessment Unit (name, no.)

Sagavanirktok Formation Gas Hydrate, 50010201

\section{ALLOCATIONS OF POTENTIAL ADDITIONS TO RESERVES TO ECOSYSTEMS \\ Surface Allocations (uncertainty of a fixed value)}

1. Coastal Plain (CSTP)

Oil in Oil Accumulations:

Volume \% in entity

Gas in Gas Accumulations:

Volume \% in entity

2. Foothills (FTHL)

Oil in Oil Accumulations:

Volume $\%$ in entity

Gas in Gas Accumulations:

Volume $\%$ in entity

3.

Oil in Oil Accumulations:

Volume $\%$ in entity

Gas in Gas Accumulations:

Volume $\%$ in entity

4.

Oil in Oil Accumulations:

Volume $\%$ in entity

Gas in Gas Accumulations:

Volume $\%$ in entity

5.

Oil in Oil Accumulations:

Volume $\%$ in entity

Gas in Gas Accumulations:

Volume $\%$ in entity

6.

Oil in Oil Accumulations:

Volume \% in entity

Gas in Gas Accumulations:

Volume $\%$ in entity represents 30.12 area $\%$ of the $\mathrm{AU}$

minimum

mode

maximum

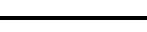

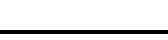
represents

30

51.68 area \% of the AU

minimum

mode

maximum

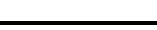

52

represents area $\%$ of the $\mathrm{AU}$

minimum

mode

maximum

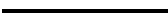

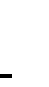
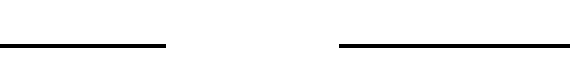

represents

area $\%$ of the $\mathrm{AU}$

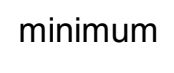

mode

maximum
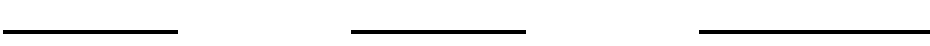

represents area $\%$ of the AU

minimum

mode

maximum represents area $\%$ of the $\mathrm{AU}$

minimum

mode maximum 
Assessment Unit (name, no.)

Sagavanirktok Formation Gas Hydrate, 50010201

7. represents area $\%$ of the $\mathrm{AU}$

Oil in Oil Accumulations: Volume $\%$ in entity

minimum

mode

maximum

Gas in Gas Accumulations:

Volume \% in entity

8. represents area $\%$ of the $\mathrm{AU}$

Oil in Oil Accumulations:

minimum

mode

maximum

Volume $\%$ in entity

Gas in Gas Accumulations:

Volume $\%$ in entity

9. represents area $\%$ of the $\mathrm{AU}$

Oil in Oil Accumulations:

minimum

Volume $\%$ in entity

mode

maximum

Gas in Gas Accumulations:

Volume \% in entity

10. represents area $\%$ of the $\mathrm{AU}$

Oil in Oil Accumulations:

Volume $\%$ in entity

minimum

mode

maximum

Gas in Gas Accumulations:

Volume $\%$ in entity

11. represents area $\%$ of the $\mathrm{AU}$

Oil in Oil Accumulations:

minimum

mode

maximum

Volume \% in entity

Gas in Gas Accumulations:

Volume $\%$ in entity

12. represents area $\%$ of the $\mathrm{AU}$

Oil in Oil Accumulations:

minimum

mode maximum

Gas in Gas Accumulations:

Volume \% in entity 
Appendix 2. Basic input data (Seventh data form) used in estimates of the numbers and sizes of undiscovered gas hydrate accumulations in the Tuluvak-Schrader Bluff-Prince Creek Formations Gas Hydrate Assessment Unit (50010202) in the Northern Alaska Gas Hydrate Total Petroleum System.

\section{SEVENTH APPROXIMATION \\ DATA FORM FOR CONVENTIONAL ASSESSMENT UNITS (Version 6, 9 April 2003)}

IDENTIFICATION INFORMATION

Assessment Geologist:

Region:

Province:

Total Petroleum System:

Assessment Unit:

Based on Data as of:

Notes from Assessor:
T.S. Collett, W.F. Agena, M.W. Lee, M.V. Zyrianova Date: North America

Northern Alaska

Nortern Alaska Gas Hydrate

Tuluvak-Schrader Bluff-Prince Creek Form Gas Hydrate Number:

$\frac{\frac{4-J u n-08}{5}}{\frac{5001}{500102}} \frac{50010202}{1}$

\section{CHARACTERISTICS OF ASSESSMENT UNIT}

Oil (<20,000 cfg/bo overall) or Gas $(\geq 20,000 \mathrm{cfg} / \mathrm{bo}$ overall): 드 Gas

What is the minimum accumulation size?

(the smallest accumulation that has potential to be added to reserves)

No. of discovered accumulations exceeding minimum size:

Established (>13 accums.)
Frontier (1-13 accums.)

Oil: $\frac{0}{\text { Hypothetical (no accums }}$

3rd 3rd 1st 3rd

Median size (grown) of discovered gas accumulations (bcfg): 1st 3rd 2nd 3rd 3rd 3rd

\section{Assessment-Unit Probabilities:}

Attribute

Probability of occurrence (0-1.0)

1. CHARGE: Adequate petroleum charge for an undiscovered accum. $>$ minimum size:

2. ROCKS: Adequate reservoirs, traps, and seals for an undiscovered accum. $\geq$ minimum size:

3. TIMING OF GEOLOGIC EVENTS: Favorable timing for an undiscovered accum. $\geq$ minimum siz

$\begin{array}{r}1.0 \\ \hline 1.0 \\ \hline 1.0 \\ \hline\end{array}$

Assessment-Unit GEOLOGIC Probability (Product of 1, 2, and 3):
1.0

\section{UNDISCOVERED ACCUMULATIONS}

No. of Undiscovered Accumulations: How many undiscovered accums. exist that are $\geq$ min. size?: (uncertainty of fixed but unknown values)

Oil Accumulations:

Gas Accumulations: minimum $(>0)$ minimum $(>0)$

mode $\frac{0}{145}$

maximum maximum

Sizes of Undiscovered Accumulations: What are the sizes (grown) of the above accums?: (variations in the sizes of undiscovered accumulations)

Oil in Oil Accumulations (mmbo):

Gas in Gas Accumulations (bcfg): minimum

minimum median median maximum maximum 
Assessment Unit (name, no.)

Tuluvak-Schrader Bluff-Prince Creek Formations Gas Hydrate, 50010202

\section{AVERAGE RATIOS FOR UNDISCOVERED ACCUMS., TO ASSESS COPRODUCTS}

(uncertainty of fixed but unknown values)

Oil Accumulations:

Gas/oil ratio (cfg/bo)

NGL/gas ratio (bngl/mmcfg)

Gas Accumulations:

Liquids/gas ratio (bliq/mmcfg)

Oil/gas ratio (bo/mmcfg)

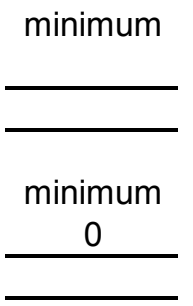

mode

maximum

SELECTED ANCILLARY DATA FOR UNDISCOVERED ACCUMULATIONS

(variations in the properties of undiscovered accumulations)

Oil Accumulations:

minimum

API gravity (degrees)

Sulfur content of oil (\%)

Depth $(\mathrm{m})$ of water (if applicable)

Drilling Depth $(m)$

Gas Accumulations:

Inert gas content (\%)

$\mathrm{CO}_{2}$ content (\%)

Hydrogen-sulfide content (\%)

Depth $(m)$ of water (if applicable)

Drilling Depth $(\mathrm{m})$

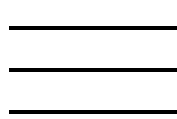

minimum mode

maximum

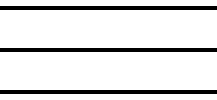

25

maximum

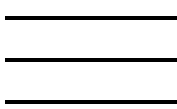

mode maximum

0

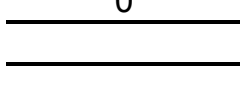


Assessment Unit (name, no.)

Tuluvak-Schrader Bluff-Prince Creek Formations Gas Hydrate, 50010202

\section{ALLOCATIONS OF POTENTIAL ADDITIONS TO RESERVES TO STATES \\ Surface Allocations (uncertainty of a fixed value)}

1. Alaska

Oil in Oil Accumulations:

Volume $\%$ in entity

Gas in Gas Accumulations:

Volume $\%$ in entity

2.

Oil in Oil Accumulations:

Volume $\%$ in entity

Gas in Gas Accumulations:

Volume $\%$ in entity

3.

Oil in Oil Accumulations:

Volume $\%$ in entity

Gas in Gas Accumulations:

Volume $\%$ in entity

4.

Oil in Oil Accumulations:

Volume $\%$ in entity

Gas in Gas Accumulations:

Volume $\%$ in entity

5.

Oil in Oil Accumulations:

Volume $\%$ in entity

Gas in Gas Accumulations:

Volume $\%$ in entity

6.

Oil in Oil Accumulations:

Volume $\%$ in entity

Gas in Gas Accumulations:

Volume $\%$ in entity represents

100 area $\%$ of the $\mathrm{AU}$

minimum

mode

maximum
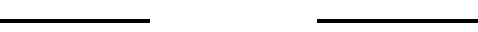

100

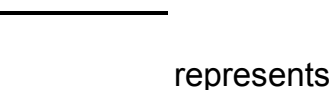

area $\%$ of the $\mathrm{AU}$

minimum

maximum
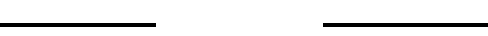
represents area $\%$ of the $\mathrm{AU}$

minimum

mode

maximum represents area $\%$ of the $\mathrm{AU}$

minimum

mode

maximum represents area $\%$ of the $\mathrm{AU}$

minimum

mode

maximum

represents area $\%$ of the $\mathrm{AU}$

mode

maximum 
7. represents area $\%$ of the $\mathrm{AU}$

Oil in Oil Accumulations: minimum

mode maximum

Volume \% in entity

Gas in Gas Accumulations:

Volume \% in entity

8. represents area $\%$ of the $\mathrm{AU}$

Oil in Oil Accumulations:

Volume \% in entity

minimum

mode

maximum

Gas in Gas Accumulations:

Volume \% in entity

9. represents area $\%$ of the $\mathrm{AU}$

Oil in Oil Accumulations:

Volume \% in entity

minimum

mode

maximum

Gas in Gas Accumulations:

Volume \% in entity

10. represents area \% of the $\mathrm{AU}$

Oil in Oil Accumulations: minimum

mode maximum Volume \% in entity

Gas in Gas Accumulations:

Volume \% in entity

11. represents area $\%$ of the $\mathrm{AU}$

Oil in Oil Accumulations:

Volume \% in entity

minimum

mode

maximum

Gas in Gas Accumulations:

Volume \% in entity

12. represents area $\%$ of the $\mathrm{AU}$

Oil in Oil Accumulations: minimum

mode

maximum

Volume \% in entity

Gas in Gas Accumulations:

Volume \% in entity 
Assessment Unit (name, no.)

Tuluvak-Schrader Bluff-Prince Creek Formations Gas Hydrate, 50010202

\section{ALLOCATIONS OF POTENTIAL ADDITIONS TO RESERVES TO LAND ENTITIES Surface Allocations (uncertainty of a fixed value)}

1. Federal Lands

Oil in Oil Accumulations:

Volume \% in entity

Gas in Gas Accumulations:

Volume $\%$ in entity

2. Private Lands

Oil in Oil Accumulations:

Volume $\%$ in entity

Gas in Gas Accumulations:

Volume $\%$ in entity

3. Tribal Lands

Oil in Oil Accumulations:

Volume $\%$ in entity

Gas in Gas Accumulations:

Volume $\%$ in entity

4. Other Lands

Oil in Oil Accumulations:

Volume $\%$ in entity

Gas in Gas Accumulations:

Volume $\%$ in entity

5. AK State Lands

Oil in Oil Accumulations:

Volume $\%$ in entity

Gas in Gas Accumulations:

Volume $\%$ in entity

6. AK Offshore

Oil in Oil Accumulations:

Volume $\%$ in entity

Gas in Gas Accumulations:

Volume $\%$ in entity

represents 43.47 area $\%$ of the $\mathrm{AU}$

minimum

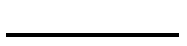

$\longrightarrow$ represents

minimum
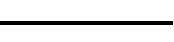

$\longrightarrow$ represents

minimum

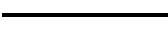
(1)

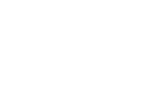

mode maximum area $\%$ of the $\mathrm{AU}$

mode

maximum

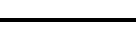

0.00

s

3.48 area $\%$ of the $\mathrm{AU}$

$$
\text { mode }
$$

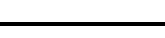

4.00

represents

1.07 area $\%$ of the $A U$

minimum

mode

maximum

1.00

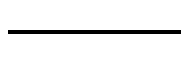
represents

45.35 area $\%$ of the $\mathrm{AU}$

minimum

mode

maximum

mode

38.00

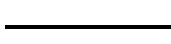

represents

6.59 area $\%$ of the $\mathrm{AU}$

minimum

mode

maximum 
7. represents area $\%$ of the $\mathrm{AU}$

Oil in Oil Accumulations: Volume \% in entity

\section{minimum}

$\longrightarrow$

Gas in Gas Accumulations:

Volume $\%$ in entity

8.

Oil in Oil Accumulations:

Volume \% in entity

Gas in Gas Accumulations:

Volume $\%$ in entity

9.

Oil in Oil Accumulations:

Volume $\%$ in entity

Gas in Gas Accumulations:

Volume $\%$ in entity

10.

Oil in Oil Accumulations:

Volume $\%$ in entity

Gas in Gas Accumulations:

Volume $\%$ in entity

11.

Oil in Oil Accumulations:

Volume $\%$ in entity

Gas in Gas Accumulations:

Volume $\%$ in entity

12.

Oil in Oil Accumulations:

Volume $\%$ in entity

Gas in Gas Accumulations:

Volume $\%$ in entity represents area $\%$ of the $\mathrm{AU}$

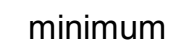

mode

maximum

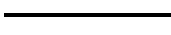

$\longrightarrow$

$\overline{-}$ represents area $\%$ of the $\mathrm{AU}$

\section{minimum}

mode

maximum

represents area $\%$ of the $\mathrm{AU}$

\section{minimum}

mode

maximum represents area $\%$ of the $\mathrm{AU}$

\section{minimum}

mode

maximum represents area $\%$ of the $A U$

minimum

mode

maximum 
Assessment Unit (name, no.)

Tuluvak-Schrader Bluff-Prince Creek Formations Gas Hydrate, 50010202

\section{ALLOCATIONS OF POTENTIAL ADDITIONS TO RESERVES TO FEDERAL LAND SUBDIVISIONS Surface Allocations (uncertainty of a fixed value)}

1. Bureau of Land Management (BLM) represents 43.47 area $\%$ of the $\mathrm{AU}$

Oil in Oil Accumulations:

Volume \% in entity

minimum

mode

maximum

Gas in Gas Accumulations:

Volume \% in entity

50

2. BLM Wilderness Areas (BLMW)

represents area $\%$ of the $\mathrm{AU}$

Oil in Oil Accumulations:

Volume $\%$ in entity

minimum

mode

maximum

Gas in Gas Accumulations:

Volume \% in entity

3. BLM Roadless Areas (BLMR) represents area $\%$ of the $\mathrm{AU}$

Oil in Oil Accumulations: minimum

mode maximum

Volume \% in entity

Gas in Gas Accumulations:

Volume \% in entity

4. National Park Service (NPS)

represents

minimum

Oil in Oil Accumulations:

Volume \% in entity

Gas in Gas Accumulations:

Volume \% in entity

5. NPS Wilderness Areas (NPSW)

Oil in Oil Accumulations:

Volume \% in entity

Gas in Gas Accumulations:

Volume \% in entity

6. NPS Protected Withdrawals (NPSP)

Oil in Oil Accumulations:

Volume \% in entity

Gas in Gas Accumulations:

Volume \% in entity represents area $\%$ of the $\mathrm{AU}$

minimum

maximum represents area $\%$ of the $\mathrm{AU}$

minimum

mode

maximum 
Assessment Unit (name, no.)

Tuluvak-Schrader Bluff-Prince Creek Formations Gas Hydrate, 50010202

7. US Forest Service (FS) represents area $\%$ of the $\mathrm{AU}$

Oil in Oil Accumulations:

Volume $\%$ in entity

minimum

mode

maximum

Gas in Gas Accumulations:

Volume $\%$ in entity

8. USFS Wilderness Areas (FSW)

represents area $\%$ of the $\mathrm{AU}$

Oil in Oil Accumulations:

Volume $\%$ in entity

minimum

mode

maximum

Gas in Gas Accumulations:

Volume $\%$ in entity

9. USFS Roadless Areas (FSR) represents area $\%$ of the AU

Oil in Oil Accumulations:

Volume $\%$ in entity

minimum

mode

maximum

Gas in Gas Accumulations:

Volume $\%$ in entity

10. USFS Protected Withdrawals (FSP)

represents area $\%$ of the $\mathrm{AU}$

Oil in Oil Accumulations:

Volume \% in entity

minimum

mode

maximum

Gas in Gas Accumulations:

Volume $\%$ in entity

11. US Fish and Wildlife Service (FWS)

represents

area $\%$ of the $\mathrm{AU}$

Oil in Oil Accumulations:

minimum

maximum

Volume $\%$ in entity

Gas in Gas Accumulations:

Volume $\%$ in entity

12. USFWS Wilderness Areas (FWSW)

represents area $\%$ of the $\mathrm{AU}$

Oil in Oil Accumulations:

minimum

mode

maximum

Gas in Gas Accumulations:

Volume $\%$ in entity 
Assessment Unit (name, no.)

Tuluvak-Schrader Bluff-Prince Creek Formations Gas Hydrate, 50010202

13. USFWS Protected Withdrawals (FWSP) represents area $\%$ of the $\mathrm{AU}$

Oil in Oil Accumulations:

Volume \% in entity

minimum

mode

maximum

Gas in Gas Accumulations:

Volume \% in entity

14. Wilderness Study Areas (WS) represents area $\%$ of the $\mathrm{AU}$

Oil in Oil Accumulations:

Volume $\%$ in entity

minimum

mode

maximum

Gas in Gas Accumulations:

Volume $\%$ in entity

15. Department of Energy (DOE) represents area $\%$ of the $\mathrm{AU}$

Oil in Oil Accumulations:

minimum

Volume $\%$ in entity

Gas in Gas Accumulations:

Volume $\%$ in entity

16. Department of Defense (DOD) represents area $\%$ of the $\mathrm{AU}$

Oil in Oil Accumulations:

Volume $\%$ in entity

minimum

mode

maximum

Gas in Gas Accumulations:

Volume \% in entity

17. Bureau of Reclamation (BOR)

represents area $\%$ of the $\mathrm{AU}$

Oil in Oil Accumulations:

minimum

maximum

Volume \% in entity

Gas in Gas Accumulations:

Volume \% in entity

18. Tennessee Valley Authority (TVA)

represents area $\%$ of the $\mathrm{AU}$

Oil in Oil Accumulations:

minimum

mode

maximum

Gas in Gas Accumulations:

Volume \% in entity 
Assessment Unit (name, no.)

Tuluvak-Schrader Bluff-Prince Creek Formations Gas Hydrate, 50010202

19. Other Federal represents area $\%$ of the $\mathrm{AU}$

Oil in Oil Accumulations: Volume \% in entity

Gas in Gas Accumulations: Volume \% in entity

20. represents area $\%$ of the $\mathrm{AU}$

Oil in Oil Accumulations: maximum minimum

$$
\text { minimum }
$$

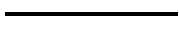

. mode

mode

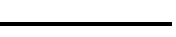

maximum

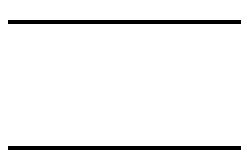

AU

Volume $\%$ in entity

Gas in Gas Accumulations:

Volume \% in entity 
Assessment Unit (name, no.)

Tuluvak-Schrader Bluff-Prince Creek Formations Gas Hydrate, 50010202

\section{ALLOCATIONS OF POTENTIAL ADDITIONS TO RESERVES TO ECOSYSTEMS Surface Allocations (uncertainty of a fixed value)}

1. Coastal Plain (CSTP)

Oil in Oil Accumulations:

Volume $\%$ in entity

Gas in Gas Accumulations:

Volume \% in entity

2. Foothills (FTHL)

Oil in Oil Accumulations:

Volume $\%$ in entity

Gas in Gas Accumulations:

Volume $\%$ in entity

3.

Oil in Oil Accumulations:

Volume $\%$ in entity

Gas in Gas Accumulations:

Volume $\%$ in entity

4.

Oil in Oil Accumulations:

Volume $\%$ in entity

Gas in Gas Accumulations:

Volume $\%$ in entity

5.

Oil in Oil Accumulations:

Volume $\%$ in entity

Gas in Gas Accumulations:

Volume $\%$ in entity

6.

Oil in Oil Accumulations:

Volume $\%$ in entity

Gas in Gas Accumulations:

Volume $\%$ in entity represents 31.29 area $\%$ of the $\mathrm{AU}$

minimum

mode

maximum

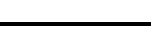

\section{1}

represents

62.12

area $\%$ of the AU

minimum

mode

maximum
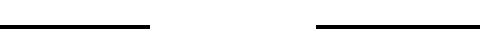

62

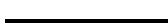

represents area \% of the AU

minimum

mode

maximum

represents area \% of the AU

minimum

mode

maximum represents area $\%$ of the $\mathrm{AU}$

minimum

mode

maximum

represents area $\%$ of the $\mathrm{AU}$

minimum

mode

maximum 
Assessment Unit (name, no.)

Tuluvak-Schrader Bluff-Prince Creek Formations Gas Hydrate, 50010202

7. represents area $\%$ of the $\mathrm{AU}$

Oil in Oil Accumulations:

minimum

mode

maximum

Volume \% in entity

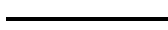

Gas in Gas Accumulations:

Volume \% in entity

8. represents area $\%$ of the $\mathrm{AU}$

Oil in Oil Accumulations: minimum

Volume \% in entity

mode

maximum

Gas in Gas Accumulations:

Volume \% in entity

9. represents area $\%$ of the $\mathrm{AU}$

Oil in Oil Accumulations:

Volume \% in entity

minimum

mode

maximum

Gas in Gas Accumulations:

Volume \% in entity

10. represents area $\%$ of the $\mathrm{AU}$

Oil in Oil Accumulations:

Volume \% in entity

minimum

mode

maximum

Gas in Gas Accumulations:

Volume \% in entity

11. represents area $\%$ of the $\mathrm{AU}$

Oil in Oil Accumulations:

Volume \% in entity

minimum

mode

maximum

Gas in Gas Accumulations:

Volume $\%$ in entity

12. represents area $\%$ of the $\mathrm{AU}$

Oil in Oil Accumulations:

minimum

mode

maximum

Gas in Gas Accumulations:

Volume \% in entity 
Appendix 3. Basic input data (Seventh data form) used in estimates of the numbers and sizes of undiscovered gas hydrate accumulations in the Nanushuk Formation Gas Hydrate Assessment Unit (50010203) in the Northern Alaska Gas Hydrate Total Petroleum System.

\section{SEVENTH APPROXIMATION \\ DATA FORM FOR CONVENTIONAL ASSESSMENT UNITS (Version 6, 9 April 2003)}

IDENTIFICATION INFORMATION

Assessment Geologist:

Region:

Province:

Total Petroleum System:

Assessment Unit:

Based on Data as of:

Notes from Assessor:
T.S. Collett, W.F. Agena, M.W. Lee, M.V. Zyrianova North America

Northern Alaska

Nortern Alaska Gas Hydrate

Nanushuk Formation Gas Hydrate
Date: 4-Jun-08

Number: 5

Number: 5001

Number: 500102

Number: 50010203

\section{CHARACTERISTICS OF ASSESSMENT UNIT}

Oil ( $<20,000 \mathrm{cfg} / \mathrm{bo}$ overall) or Gas $(\geq 20,000 \mathrm{cfg} / \mathrm{bo}$ overall): ㄴ. Gas

What is the minimum accumulation size? $\quad 3.33$ mmboe grown

(the smallest accumulation that has potential to be added to reserves)

No. of discovered accumulations exceeding minimum size:

Established (>13 accums.)
Frontier (1-13 accums.)

Oil: $\frac{0}{\text { Hypothetical (no accums }}$

3rd 3rd 1 st 3rd

Median size (grown) of discovered gas accumulations (bcfg): 1 st 3 rd

3rd 3rd

Assessment-Unit Probabilities:

Attribute

Probability of occurrence $(0-1.0)$

1. CHARGE: Adequate petroleum charge for an undiscovered accum. $\geq$ minimum size:

2. ROCKS: Adequate reservoirs, traps, and seals for an undiscovered accum. $\geq$ minimum size:

3. TIMING OF GEOLOGIC EVENTS: Favorable timing for an undiscovered accum. $\geq$ minimum siz

$\begin{array}{r}1.0 \\ \hline 1.0 \\ \hline 1.0 \\ \hline\end{array}$

Assessment-Unit GEOLOGIC Probability (Product of 1, 2, and 3):

\section{UNDISCOVERED ACCUMULATIONS}

No. of Undiscovered Accumulations: How many undiscovered accums. exist that are $\geq$ min. size?: (uncertainty of fixed but unknown values)

Oil Accumulations: Gas Accumulations:

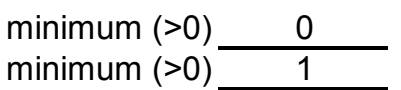

mode

$\frac{0}{195}$

maximum maximum

$\frac{0}{600}$

Sizes of Undiscovered Accumulations: What are the sizes (grown) of the above accums?: (variations in the sizes of undiscovered accumulations)

Oil in Oil Accumulations (mmbo): Gas in Gas Accumulations (bcfg): minimum

minimum median

median maximum maximum 
Assessment Unit (name, no.)

Nanushuk Formation Gas Hydrate, 50010203

\section{AVERAGE RATIOS FOR UNDISCOVERED ACCUMS., TO ASSESS COPRODUCTS}

(uncertainty of fixed but unknown values)

Oil Accumulations:

minimum

Gas/oil ratio (cfg/bo)

$\mathrm{NGL} / \mathrm{gas}$ ratio (bngl/mmcfg)

Gas Accumulations:

Liquids/gas ratio (bliq/mmcfg)

Oil/gas ratio (bo/mmcfg)

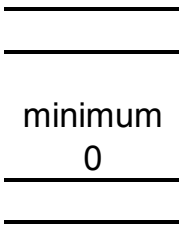

mode

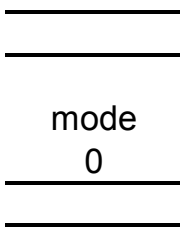

maximum

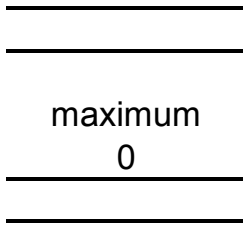

SELECTED ANCILLARY DATA FOR UNDISCOVERED ACCUMULATIONS

(variations in the properties of undiscovered accumulations)

Oil Accumulations:

API gravity (degrees)

Sulfur content of oil (\%)

Depth $(m)$ of water (if applicable)

Drilling Depth (m)

Gas Accumulations:

Inert gas content (\%)

$\mathrm{CO}_{2}$ content (\%)

Hydrogen-sulfide content (\%)

Depth $(\mathrm{m})$ of water (if applicable)

Drilling Depth (m) minimum

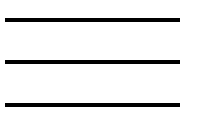

minimum mode

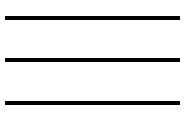

F75

mode

F25

maximum

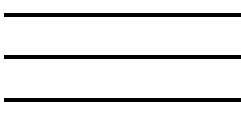

maximum

minimum

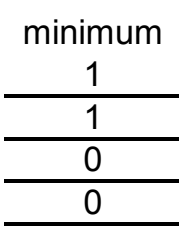

minimum

300

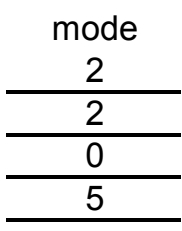

F75

mode 600

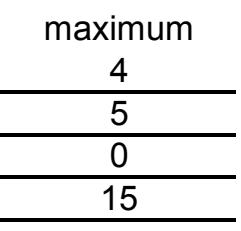

F25

maximum 
Assessment Unit (name, no.)

Nanushuk Formation Gas Hydrate, 50010203

\section{ALLOCATIONS OF POTENTIAL ADDITIONS TO RESERVES TO STATES \\ Surface Allocations (uncertainty of a fixed value)}

1. Alaska

Oil in Oil Accumulations:

Volume $\%$ in entity

Gas in Gas Accumulations:

Volume \% in entity

2.

Oil in Oil Accumulations:

Volume \% in entity

Gas in Gas Accumulations:

Volume \% in entity

3.

Oil in Oil Accumulations:

Volume \% in entity

Gas in Gas Accumulations:

Volume \% in entity

4.

Oil in Oil Accumulations:

Volume \% in entity

Gas in Gas Accumulations:

Volume \% in entity

5.

Oil in Oil Accumulations:

Volume \% in entity

Gas in Gas Accumulations:

Volume \% in entity

6.

Oil in Oil Accumulations:

Volume $\%$ in entity

Gas in Gas Accumulations:

Volume $\%$ in entity

represents

100 area \% of the $\mathrm{AU}$

minimum

mode

maximum
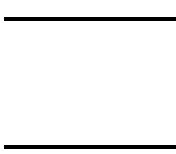

represents

100

mode

area $\%$ of the $\mathrm{AU}$

minimum

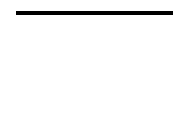

$\longrightarrow$

represents area $\%$ of the $\mathrm{AU}$

minimum

mode

maximum
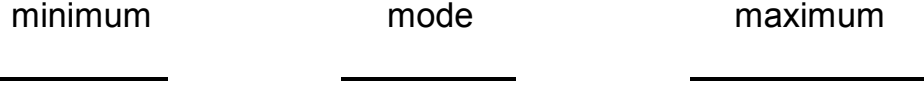

maximum

(r)


Assessment Unit (name, no.)

Nanushuk Formation Gas Hydrate, 50010203

7. represents area $\%$ of the $\mathrm{AU}$

Oil in Oil Accumulations:

minimum

mode

maximum

Volume \% in entity

Gas in Gas Accumulations:

Volume $\%$ in entity

8. represents area $\%$ of the $\mathrm{AU}$

Oil in Oil Accumulations:

Volume $\%$ in entity

minimum

mode

maximum

Gas in Gas Accumulations:

Volume $\%$ in entity

9. represents area $\%$ of the $\mathrm{AU}$

Oil in Oil Accumulations:

minimum

mode

maximum

Volume \% in entity

Gas in Gas Accumulations:

Volume $\%$ in entity

10. represents area $\%$ of the $\mathrm{AU}$

Oil in Oil Accumulations:

Volume \% in entity

minimum

mode

maximum

Gas in Gas Accumulations:

Volume \% in entity

11. represents area $\%$ of the $\mathrm{AU}$

Oil in Oil Accumulations:

minimum

mode

maximum

Volume \% in entity

Gas in Gas Accumulations:

Volume $\%$ in entity

12. represents area $\%$ of the $\mathrm{AU}$

Oil in Oil Accumulations:

minimum

mode maximum

Gas in Gas Accumulations:

Volume $\%$ in entity 
Assessment Unit (name, no.)

Nanushuk Formation Gas Hydrate, 50010203

\section{ALLOCATIONS OF POTENTIAL ADDITIONS TO RESERVES TO LAND ENTITIES \\ Surface Allocations (uncertainty of a fixed value)}

1. Federal Lands

Oil in Oil Accumulations:

Volume \% in entity

Gas in Gas Accumulations:

Volume \% in entity

2. Private Lands

Oil in Oil Accumulations:

Volume $\%$ in entity

Gas in Gas Accumulations:

Volume $\%$ in entity

3. Tribal Lands

Oil in Oil Accumulations:

Volume \% in entity

Gas in Gas Accumulations:

Volume $\%$ in entity

4. Other Lands

Oil in Oil Accumulations:

Volume $\%$ in entity

Gas in Gas Accumulations:

Volume $\%$ in entity

5. AK State Lands

Oil in Oil Accumulations:

Volume $\%$ in entity

Gas in Gas Accumulations:

Volume $\%$ in entity

6. AK Offshore

Oil in Oil Accumulations:

Volume $\%$ in entity

Gas in Gas Accumulations:

Volume $\%$ in entity represents 81.50 area $\%$ of the $\mathrm{AU}$

minimum

mode

maximum

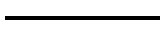

$\longrightarrow$ represents

81.00

0.01 area $\%$ of the $\mathrm{AU}$

minimum

mode

maximum

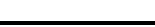

0.00

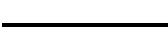
represents

5.00 area $\%$ of the $\mathrm{AU}$

minimum

mode

maximum

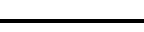

5.00

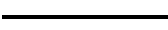

represents

0.50

area $\%$ of the $\mathrm{AU}$

minimum

mode

maximum

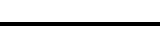

1.00

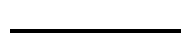

represents

8.56

area $\%$ of the $\mathrm{AU}$

minimum

mode

maximum

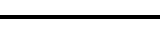

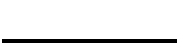

9.00

represents

4.43

area $\%$ of the $\mathrm{AU}$

minimum

mode

maximum 
Assessment Unit (name, no.)

Nanushuk Formation Gas Hydrate, 50010203

7. represents area $\%$ of the $\mathrm{AU}$

Oil in Oil Accumulations: minimum mode maximum

Volume \% in entity

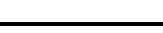

Gas in Gas Accumulations:

Volume $\%$ in entity

8. represents area $\%$ of the $\mathrm{AU}$

Oil in Oil Accumulations:

minimum

mode

maximum

Volume $\%$ in entity

Gas in Gas Accumulations:

Volume $\%$ in entity

9. represents area $\%$ of the $\mathrm{AU}$

Oil in Oil Accumulations:

minimum

Volume $\%$ in entity

mode

maximum

Gas in Gas Accumulations:

Volume \% in entity

10. represents area $\%$ of the $\mathrm{AU}$

Oil in Oil Accumulations:

Volume $\%$ in entity

minimum

mode

maximum

Gas in Gas Accumulations:

Volume $\%$ in entity

11. represents area $\%$ of the $\mathrm{AU}$

Oil in Oil Accumulations:

minimum

mode

maximum

Volume \% in entity

Gas in Gas Accumulations:

Volume \% in entity

12. represents area $\%$ of the $\mathrm{AU}$

Oil in Oil Accumulations:

minimum

mode maximum

Gas in Gas Accumulations:

Volume \% in entity 
Assessment Unit (name, no.)

Nanushuk Formation Gas Hydrate, 50010203

\section{ALLOCATIONS OF POTENTIAL ADDITIONS TO RESERVES TO FEDERAL LAND SUBDIVISIONS Surface Allocations (uncertainty of a fixed value)}

1. Bureau of Land Management (BLM) represents 81.49 area $\%$ of the $\mathrm{AU}$

Oil in Oil Accumulations:

minimum

mode

maximum

Volume \% in entity

Gas in Gas Accumulations:

Volume \% in entity

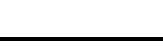

81

2. BLM Wilderness Areas (BLMW)

represents area $\%$ of the $\mathrm{AU}$

Oil in Oil Accumulations:

minimum

Volume \% in entity

mode

maximum

Gas in Gas Accumulations:

Volume $\%$ in entity

3. BLM Roadless Areas (BLMR)

represents area $\%$ of the $\mathrm{AU}$

Oil in Oil Accumulations:

minimum

Volume $\%$ in entity

Gas in Gas Accumulations:

Volume \% in entity

4. National Park Service (NPS)

represents area $\%$ of the $\mathrm{AU}$

Oil in Oil Accumulations:

minimum

mode

maximum

Volume \% in entity

Gas in Gas Accumulations:

Volume $\%$ in entity

5. NPS Wilderness Areas (NPSW)

represents area $\%$ of the $\mathrm{AU}$

Oil in Oil Accumulations:

minimum

mode

maximum

Volume \% in entity

Gas in Gas Accumulations:

Volume $\%$ in entity

6. NPS Protected Withdrawals (NPSP)

represents area $\%$ of the $\mathrm{AU}$

Oil in Oil Accumulations:

minimum

mode

maximum

Volume \% in entity

Gas in Gas Accumulations:

Volume $\%$ in entity 
Assessment Unit (name, no.)

Nanushuk Formation Gas Hydrate, 50010203

7. US Forest Service (FS)

Oil in Oil Accumulations:

Volume $\%$ in entity

Gas in Gas Accumulations:

Volume $\%$ in entity

8. USFS Wilderness Areas (FSW)

Oil in Oil Accumulations:

Volume \% in entity

Gas in Gas Accumulations:

Volume $\%$ in entity

9. USFS Roadless Areas (FSR)

Oil in Oil Accumulations:

Volume \% in entity

Gas in Gas Accumulations:

Volume \% in entity

10. USFS Protected Withdrawals (FSP)

Oil in Oil Accumulations:

Volume $\%$ in entity

Gas in Gas Accumulations:

Volume \% in entity

11. US Fish and Wildlife Service (FWS)

Oil in Oil Accumulations:

Volume $\%$ in entity

Gas in Gas Accumulations:

Volume $\%$ in entity

12. USFWS Wilderness Areas (FWSW)

Oil in Oil Accumulations:

Volume $\%$ in entity

Gas in Gas Accumulations:

Volume $\%$ in entity represents

area $\%$ of the AU

mode

maximum

minimum

represents area $\%$ of the AU

minimum

mode

maximum

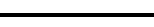
represents area $\%$ of the $\mathrm{AU}$

minimum

mode

maximum
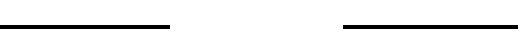

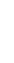

represents area $\%$ of the $\mathrm{AU}$

minimum

mode

maximum

-

.

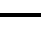
represent

minimum
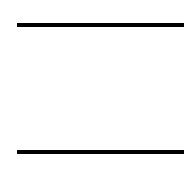
represents minimum area $\%$ of the $\mathrm{AU}$

maximum

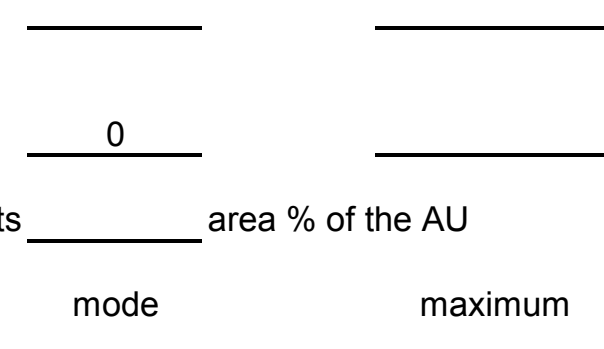

area $\%$ of the $\mathrm{AU}$

mode ${ }^{0.01}$ area $\%$ of the $\mathrm{AU}$


Assessment Unit (name, no.)

Nanushuk Formation Gas Hydrate, 50010203

13. USFWS Protected Withdrawals (FWSP) represents area $\%$ of the $\mathrm{AU}$

Oil in Oil Accumulations:

minimum

mode

maximum

Volume $\%$ in entity

Gas in Gas Accumulations:

Volume \% in entity

14. Wilderness Study Areas (WS)

represents area $\%$ of the $\mathrm{AU}$

Oil in Oil Accumulations:

Volume $\%$ in entity

minimum

mode

maximum

Gas in Gas Accumulations:

Volume $\%$ in entity

15. Department of Energy (DOE) represents area $\%$ of the $\mathrm{AU}$

Oil in Oil Accumulations:

minimum

Volume $\%$ in entity

mode

maximum

Gas in Gas Accumulations:

Volume $\%$ in entity

16. Department of Defense (DOD) represents area $\%$ of the $\mathrm{AU}$

Oil in Oil Accumulations: Volume $\%$ in entity

minimum

mode

maximum

Gas in Gas Accumulations:

Volume \% in entity

17. Bureau of Reclamation (BOR) represents area $\%$ of the $\mathrm{AU}$

Oil in Oil Accumulations:

minimum

maximum

Volume \% in entity

Gas in Gas Accumulations:

Volume $\%$ in entity

18. Tennessee Valley Authority (TVA) represents area $\%$ of the $\mathrm{AU}$

Oil in Oil Accumulations:

minimum

mode maximum

Gas in Gas Accumulations:

Volume $\%$ in entity 
Assessment Unit (name, no.) Nanushuk Formation Gas Hydrate, 50010203

19. Other Federal represents area $\%$ of the $\mathrm{AU}$

Oil in Oil Accumulations: minimum

mode

Volume $\%$ in entity

Gas in Gas Accumulations:

Volume $\%$ in entity

20.

$\longrightarrow$
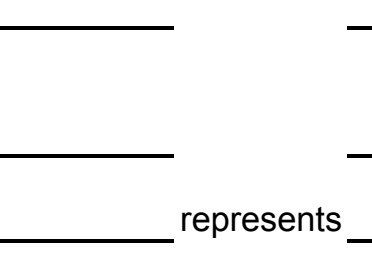
represents area $\%$ of the $\mathrm{AU}$

Oil in Oil Accumulations:

minimum

mode maximum Volume $\%$ in entity

Gas in Gas Accumulations:

Volume $\%$ in entity 
Assessment Unit (name, no.)

Nanushuk Formation Gas Hydrate, 50010203

\section{ALLOCATIONS OF POTENTIAL ADDITIONS TO RESERVES TO ECOSYSTEMS \\ Surface Allocations (uncertainty of a fixed value)}

1. Coastal Plain (CSTP)

Oil in Oil Accumulations:

Volume \% in entity

Gas in Gas Accumulations:

Volume $\%$ in entity

2. Foothills (FTHL)

Oil in Oil Accumulations:

Volume $\%$ in entity

Gas in Gas Accumulations:

Volume \% in entity

3.

Oil in Oil Accumulations:

Volume $\%$ in entity

Gas in Gas Accumulations:

Volume $\%$ in entity

4.

Oil in Oil Accumulations:

Volume $\%$ in entity

Gas in Gas Accumulations:

Volume $\%$ in entity

5.

Oil in Oil Accumulations:

Volume $\%$ in entity

Gas in Gas Accumulations:

Volume $\%$ in entity

6.

Oil in Oil Accumulations:

Volume $\%$ in entity

Gas in Gas Accumulations:

Volume $\%$ in entity represents 40.47 area $\%$ of the $\mathrm{AU}$

minimum

mode

maximum

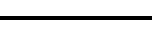

$\longrightarrow$ represents

41

55.10

area $\%$ of the $\mathrm{AU}$

minimum

mode

maximum

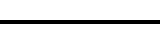

55

represents area \% of the $\mathrm{AU}$

minimum

mode

maximum

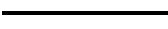

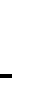

\section{rade}

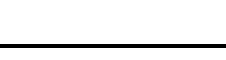

represents

area $\%$ of the $\mathrm{AU}$

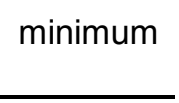

mode

maximum

represents area $\%$ of the $\mathrm{AU}$

minimum

mode

maximum represents area $\%$ of the $\mathrm{AU}$

minimum

mode maximum 
Assessment Unit (name, no.)

Nanushuk Formation Gas Hydrate, 50010203

7.

Oil in Oil Accumulations:

Volume $\%$ in entity

Gas in Gas Accumulations:

Volume \% in entity

8.

Oil in Oil Accumulations:

Volume $\%$ in entity

Gas in Gas Accumulations:

Volume $\%$ in entity

9.

Oil in Oil Accumulations:

Volume $\%$ in entity

Gas in Gas Accumulations:

Volume $\%$ in entity

10.

Oil in Oil Accumulations:

Volume $\%$ in entity

Gas in Gas Accumulations:

Volume $\%$ in entity

11.

Oil in Oil Accumulations:

Volume \% in entity

Gas in Gas Accumulations:

Volume $\%$ in entity

12.

Oil in Oil Accumulations:

Volume $\%$ in entity

Gas in Gas Accumulations:

Volume \% in entity represents

area $\%$ of the $\mathrm{AU}$

mode

maximum

minimum
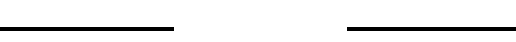

(2)
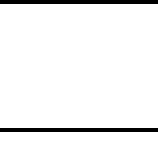

represents area $\%$ of the $\mathrm{AU}$

minimum

mode

maximum
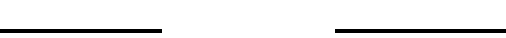

(2)

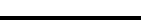
represents area $\%$ of the $\mathrm{AU}$

minimum

mode

maximum
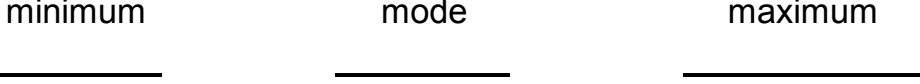

mode

area $\%$ of the $\mathrm{AU}$

minimum

represents

maximum

represents area $\%$ of the $\mathrm{AU}$

mode

maximum

minimum



(

represents

mode

minimum



area $\%$ of the $\mathrm{AU}$

maximum

-




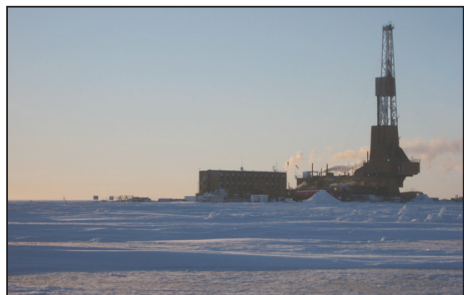

Click here to return to Main Contents

Publishing support provided by:

Denver Publishing Service Center, Denver, Colorado

For more information concerning this publication, contact:

Center Director, USGS Central Energy Resources Science Center Box 25046, Mail Stop 939

Denver, C0 80225

(303) 236-1647

Or visit the Central Energy Resources Science Center Web site at: http://energy.usgs.gov/

This report is available at: $h t t p: / / d x . d o i . o r g / 10.3133 / d d s 69 c c$. 


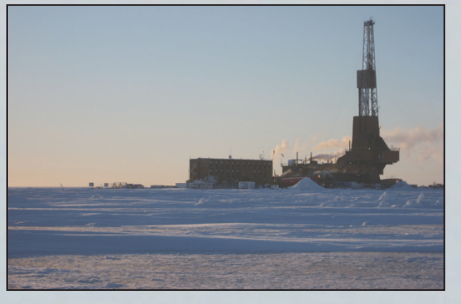

Click here to return to

Main Contents
ISSN 2327-132X (online)

ISSN 2327-0271 (print)

http://dx.doi.org/10.3133/dss69cc

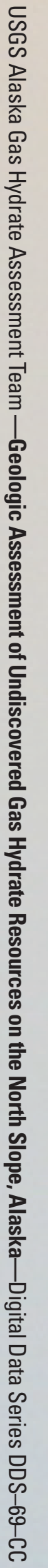

